NATL INST OF STANDAADS \& TECH R.IC. 




BUILDING SCIENCE SERIES

TA435

1458

2 OCT

Reference book not to be taken from the library.

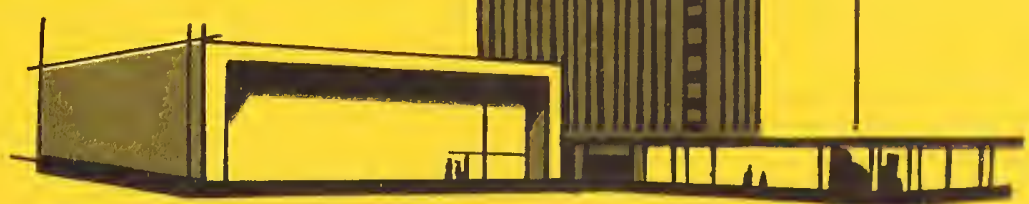

Interrelations

between

Cement \& Concrete

Properties

PART 1

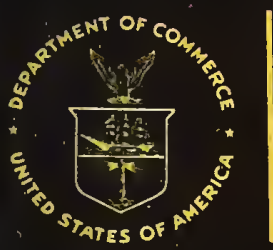

U.S. DEPARTMENT OF COMMERCE

National Bureau of Standards 


\section{Announcing The-Building Science Series}

The "Building Science Series" disseminates technical information developed at the Bureau on building materials, components, systems, and whole structures. The series presents research results, test methods, and performance criteria related to the structural and environmental functions and the durability and safety characteristics of building elements and systems.

These publications, similar in style and content to the NBS Building Materials and Structure Reports (1938-59), are directed toward the manufacturing, design, and construction segments of the building industry, standards organizations, officials responsible for building codes, and scientists and engineers concerned with the properties of building materials.

The material for this series originates principally in the Building Research Division of the NBS Institute for Applied Technology. Published or in preparation are:

*

BSS-1. Building Research at the National Bureau of Standards. (In preparation.)

*

BSS-2. Interrelations Between Cement and Concrete Properties, Part I. (This publication.)

BSS-3. Doors as Barriers to Fire and Smoke. (In preparation.)

[See mailing list announcement on last page.] 
UNITED STATES DEPARTMENT OF COMMERCE • John T. Connor, Secretary NATIONAL BUREAU OF STANDARdS • A. V. Astin, Director

\title{
Interrelations Between Cement and Concrete Properties, Part 1
}

Materials, Techniques, Water, Requirements and Trace Elements

\author{
R. L. Blaine, H. T. Arni, B. E. Foster, et al.
}

Building Research Division

Institute of Applied Technology

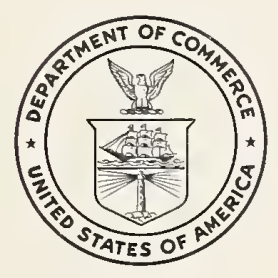

Building Science Series 2

Issued August 20, 1965 


\section{RELATED PUBLICATIONS}

NBS Monograph 28-Causes of Variation in Chemical Analyses and Physical Tests of Portland Cement-25 cents*

NBS Monograph 43-Chemistry of Cement

Proceedings of the Fourth Int ernational Symposium-Washington 1960. Presented in two volumes. Volume I-\$6.50. Volume II-\$6.25. The two volumes at $\$ 12.75$ a set.* (Originally issued September 1962, and reprinted Feburary (1964).

*Order publications from Superintendent of Documents, Government Printing Office, Washington, D.C., 20402. (For foreign mailing, add one-fourth of the price of the publication.)

II 


\section{Foreword}

In studies at the National Bureau of Standards on the interrelations between cement and concrete properties, many different tests were made on a large number of portland cements. Because of the large quantity of data obtained and the variety of tests performed, the results of these studies are being published as a series of related sections each dealing with different aspects of the properties and analyses.

This publication presents the first three sections which deal primarily with the materials, general test methods and statistical analyses employed throughout the series. Reference will be made to this first section in subsequent parts of the series. Included in this first part are a section on water requirements of neat pastes, mortars and concrete and a section on the occurrence of minor and trace elements in portland cements. Other parts will include studies of sulfate expansion, heat of hydration, autoclave expansion, compressive strength after normal and steam curing, shrinkage, absorption, freeze-thaw durability, as well as the effect of outdoor exposure on concrete specimens.

A. V. Astin, Director. 


\section{Contents}

Section 1. Materials and techniques

R. L. Blaine, H. T. Arni, and B. E. Foster

Section 2. Water requirements of portland cement

R. L. Blaine, H. T. Arni, and R. A. Clevenger

Section 3. Occurrence of minor and trace elements in portland cement

R. L. Blaine, Leonard Bean, and Elizabeth K. Hubbard 


\title{
Section 1. Materials and Techniques
}

\author{
R. L. Blaine, H. T. Arni, and B. E. Foster
}

\begin{abstract}
The studies of the interrelations between cement and concrete properties are presented in a series of related articles. This first section presents the type classification of the cements and the areas from which they were procured together with the tests performed on the cements and concretes. Also presented are the methods employed in the statistical treatment of the data and a discussion of the significance of the various statistical techniques employed in the following sections dealing with specific aspects of the interrelations between cement and concrete properties.
\end{abstract}

\section{Contents}

1. Introduction $\ldots \ldots$

2. Cements and concretes $\ldots \ldots$

3. Nomenclature

4. Statistical treatment of the data 4.1. Preliminary exploratory techniques.....4.2. Fitting of regression equations $\ldots \ldots \ldots$ 4.3. Further exploratory techniques

5. Limitations on interpretation of statistical studies. -

6. Summary and conclusions

7. References

Page
1
2
3
4
5
6
8
9
11
11

\section{Introduction}

The study of the interrelations between cement and concrete properties on which this and succeeding sections are based was started in 1953. The purposes for which it was undertaken were: (1) To review the properties of cements then being manufactured; (2) to study further the extent to which specification tests could predict the properties at later ages of the cements and concretes; and (3) to discover, if possible, better criteria for such predictions. In order to achieve these ends, 199 portland cements of the various specification types were procured from different manufacturers and areas of the United States including a few from other countries.

This first section presents information on the sources and types of cements, and a general description of test procedures used in the study. Also presented are the statistical methods employed in analyzing the data and a discussion of the various techniques used. The material in this section will be referred to in the following sections of this series of papers.

This project produced a collection of data so vast (data on the field specimens are still being acquired) that no adequate analysis was feasible until a modern high-speed digital computer became available. The study has certain characteristics common to many others of a similar nature over the country. Some of the data reflect the imposed restraints of manufacturing to specifications, which often severely limits the range of the variables that are studied. Also, many of the vari- ables are more or less correlated in the values that are available, and this further complicates the problem of interpretation.

It is probably true that, per unit of data, such accumulated records have a low efficiency in yielding information in comparison with carefully planned experiments. In the cement and concrete field, however, synthetic cements formulated to certain compositions, although useful and important in studying the underlying reactions involved in cement manufacture and use, do not really reflect in performance the "commercial" product, and there is at present no alternative to using the records of actual cements in an endeavor to relate performance to various physical and chemical tests. The present study is an exploration which aims to put on record a large array of combinations of variables that were tried as predictor's of performance, and it is hoped that some of the indications arising from this work will point the way to some avenues of fruitful research for other investigations.

A number of statistical devices, of varying degrees of power and sophistication, have been used to determine what factors may be associated with properties of the cements and concretes, and to what extent. The most refined tool, used in all cases, was the fitting of multivariable regression equations to the data, with various simpler techques being used previously to determine what variables out of the many a vailable might be tried in the fitted equations. The various techniques will 
be explained in more detail in this section in order to give the nonstatistically trained reader an understanding of what was done and of the significance of the results.

In the Fourth International Symposium on the Chemistry of Cement held in Washington, D.C., in $1960.0^{1}$ [1] a number of articles were presented stressing the importance of certain minor and trace elements in their effect on the properties of portland cements. There have also been other reports on the effects of these elements $[2,3,4]$. Con- sequently, part of the work of this study has been devoted to a search for significant relationships between the amounts of these elements and the various properties.

In view of the number of properties and tests involved, it has appeared desirable to divide the subject matter into sections, each concerning a different subject. A series of sections will therefore be presented dealing with different properties, such as water requirements, minor constitutents, potential sulfate expansion, shrinkage, heat of hydration, strength, freeze-thaw durability, etc.

\section{Cements and Concretes}

The cements used in this investigation were, for the most part, portions of samples submitted in 1953 and 1954 for test for compliance with Federal specifications. However, some of the cements of different types were donated by the manufacturers and some were purchased from dealers. The number of cements from different areas is listed in table 1-1.

The cements were classified principally on the basis of their chemical composition. The number of cements in each of the type classifications is presented in table 1-2.

Each of the cements was thoroughly mixed in a blender when available or by rolling on a suitable sheet of plastic. The cements were stored in sealed metal containers until tested.

In addition to the usual specification acceptance tests, other test were made, which included spectrochemical determination of minor and trace elements, mortar strength tests at ages up to 10 years, modulus of rupture and dynamic modulus of elasticity for mortar specimens, potential sulfate expansion, shrinkage of neat cement bars, and time of breaking in a ring shrinkage test described in future sections.

TABLE 1-1. The number of cements from each of the various areas indicated

\begin{tabular}{|c|c|}
\hline No. of cements & Location \\
\hline 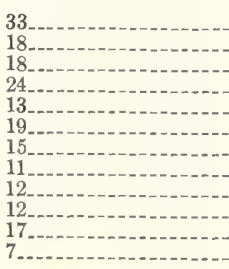 & $\begin{array}{l}\text { Eastern Pa., Md. } \\
\text { New York, Maine. } \\
\text { Ohio, Western Pa., W. Va., Mich. } \\
\text { Ill. Ind., Ky., Wis., Ala., Tenn. } \\
\text { Va., Ga., Fla., La., S. Car., Miss. } \\
\text { Iowa, Eastern Mo., Minn., S.D., Kans. } \\
\text { Western Mo., Neb., Okla., Ark., Tex. } \\
\text { Colo., Ariz., Mont., Utah, Idaho } \\
\text { Northern Calif. } \\
\text { Southern Calif. } \\
\text { Wash., Ore. } \\
\text { Other than USA }\end{array}$ \\
\hline
\end{tabular}

Chemical analyses of these cements were made at either the Seattle or the Washington laboratories of the National Bureau of Standards by the optional methods outlined in Federal Specifications SS-C-158c [6], except that the sulfur-trioxide determinations were made by the gravimetric method, sodium and potassium oxides were

\footnotetext{
1 Figures in brackets indicate the literature references at the end of this section, p. 11 .
}

TABLE 1-2. The number of cements of each of the type classifications

\begin{tabular}{l|r}
\hline \multicolumn{1}{c|}{ Type cement } & Number of cements \\
\hline I & 82 \\
IA & 8 \\
II & $* 8$ \\
IIA & $* * 20$ \\
III & 3 \\
IIIA & 3 \\
IV & 12 \\
\hline
\end{tabular}

* 16 of these were classiued as type I in 1953-54 at the time of procurement. ${ }^{*}{ }^{*} 1$ of these was classified as type IA at the time of procurement.

${ }^{* * *}$ Some of these cements would also meet the present requirements for moderate sulfate resisting high early strength cements [5].

determined by the standard Federal and ASTM flame-photometric methods $[6,7]$, and strontium oxide was determined by means of the flame photometer as described by Diamond [8]. Other chemical elements plesent in minor quantities were determined by a semiquantitative spectrochemical method which will be more fully described in a subsequent section.

The quantities of water used for normal consistency of neat cement pastes and those necessary to produce a $1: 2.75$ cement to graded Ottawa sand mortar and 1:4 standard Ottawa sand mortar of standard consistency were determined by procedures outlined in Federal Test Method Standards SS-C-158c [6] and the corresponding ASTM methods of test for Hydraulic Cement Mortars $[9,10,11]$, in effect at that time. The tolerances on the flow values were chosen less than those permitted by the specifications in that the amount of water required for a flow of $90 \pm 5$ was used for the 1:4 mortars and an amount of water required for a flow of $110 \pm 5$ was used for the 1:2.75 mortars. Three batches of $1: 2.75$ cement to graded Ottawa sand mortar were made of each of the cements in order to obtain the necessary number of test specimens. Percentage flow values were obtained on each batch and the average of these flow values reported. The values reported for water used for the $1: 4$ cement to 20-30 Ottawa sand mortar as well as those for the normal consistency of the neat cements were generally the results obtained in single determinations for the respective properties of each cement. Although most of these tests were made in the Washington 
Laboratory, some were made at the branch laboratories at Allentown, Pa., Denver, Colo., San Francisco, Calif., and Seattle, Wash. Regularly conducted inter-laboratory tests on another series of cements as well as calibrations of equipment and techniques were employed to minimize as much as possible laboratory and operator differences.

More detailed descriptions of the test methr ds will be presented when necessary in following sections dealing with specific properties.

Two series of concretes wers made from these cements in the Washington laboratory. One series was made with a constant water-cement ratio of 0.635. Preliminary tests had indicated that this would give a concrete having approximately a 5 -in. slump. A second series was made in which, if necessary, only the water was varied to obtain concretes of $5 \pm 1$-in. slump. In both series the ratio of cement to aggregate was held constant, and the ratio of fine to coarse aggregate was held at $1: 1$ by absolute volume throughout. The concretes prepared were of a mix design which, in preliminary tests with a particular cement, had produced concrete with a $51 / 2$-bags-per-cubic-yard cement factor and 0.75 percent air content.

A high quality rounded quartzite coarse aggregate (White Marsh) and a sand from the same source were used for making the concretes. The aggregates were dried, separated to the varions sizes and recombined when batched. The fineness modulus of the sand was 2.82 . The gradation of the sand used in the concretes is presented in table $1-3$.

The fineness modulus was 6.82 for the coarse aggregates, and 4.82 for the combined aggregates. The gradation of the coarse aggregate is given in table 1-4.

TABLE 1-3. Sand gradation used in concretes

\begin{tabular}{|c|c|}
\hline Sieve-size & Percentage \\
\hline 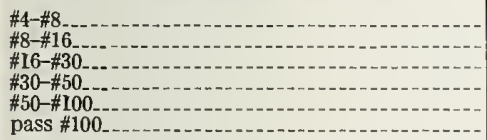 & $\begin{array}{r}18 \\
17 \\
20 \\
25 \\
14 \\
6\end{array}$ \\
\hline
\end{tabular}

TABLE 1-4. Gradation of coarse aggregate used in concretes

\begin{tabular}{|c|c|}
\hline Sieve-size & Percentage \\
\hline $\begin{array}{l}3 / 4-1 \text { in } \\
1 / 2-3 / 4 \text { in } \\
3 / 8-1 / 2 \text { in } \\
\# 4-3 / 8 \text { in }\end{array}$ & $\begin{array}{l}10 \\
35 \\
27 \\
28\end{array}$ \\
\hline
\end{tabular}

The sand and gravel were soaked overnight before preparation of the concrets.

The concrete was prepared in a tilting drum mixer with a rated capacity of $1 \mathrm{ft}^{3}$. The soaked sand and gravel and the water were mixed $11 / 2$ min. The cement was then added and mixing continued for $2 \mathrm{~min}$. The mixer was stopped for $3 \mathrm{~min}$, after which the concrete was remixed for one additional minute. Each batch of concrete was prepared in a clean, moistened mixer. Previous tests had indicated that approximately $3.2 \mathrm{lb}$ of cement-sand-water mortar was retained by the mixer when emptied. Properly proportioned anounts of these materials were added to each basic mix to provide for buttering the mixer so that each batch of concrete delivered contained $18.80 \mathrm{lb}$ cement, $56.95 \mathrm{lb}$ sand (saturated surface dry basis), 57.00 pounds coarse aggregate (saturated surface dry basis) and $11.95 \mathrm{lb}$ of water for the constant water cement ratio concrete, or a proportionate quantity of water in the constant slump concretes. After mixing, the batch was discharged into a tared pan, weighed, and adjusted to the correct delivered weight by adding mortar scraped from the mixer or subtracting mortar from the pan. The batch was then remixed with a shovel.

The slump and weight per cubic foot were determined for each batch of concrete in accordance with ASTM Designations C 143-52 [12] and C $138-44$ [13].

The desired nominal slump of the concrete mixes was $5 \pm 1 \mathrm{in}$. If the first batch of concrete prepared with the constant water-cement ratio was outside or close to the limits of this tolerance, the amount of water for the second batch was adjusted to obtain a concrete with the desired slump. Otherwise, the same amount of water was used for both batches.

From the mix proportions, weight per cubic foot, known specific gravities of aggregates and water, and assumed specific gravity of 3.15 for all cements, the air contents and actual cement factors of the batches were calculated in accordance with the requirements of ASTM Designation C 138-44 [13].

Shrinkage, expansion, absorption, dynamic modulus of elasticity, and freeze-thaw durability tests were made on the concrete specimens, and companion specimens were exposed in the field. Length change, weight, and dynamic modulus measurements have been made on the latter at periodic intervals. The test methods will be described in the following sections dealing with these properties.

\section{Nomenclature}

The nomenclature customary in cement technology, viz, $\mathrm{C}_{3} \mathrm{~A}, \mathrm{C}_{3} \mathrm{~S}, \mathrm{C}_{2} \mathrm{~S}$, and $\mathrm{C}_{4} \mathrm{AF}$, is used in this and the following sections in this series to refer to the potential compound compositions of the cements calculated by standard procedures presented in Federal and A STM specifications for portland cements $[14,15]$. The letters $\mathrm{C}, \mathrm{A}, \mathrm{F}$, and $\mathrm{S}$ will be used in referring to $\mathrm{CaO}, \mathrm{Al}_{2} \mathrm{O}_{3}, \mathrm{Fe}_{2} \mathrm{O}_{3}$, and $\mathrm{SiO}_{2}$, respectively. The $\mathrm{A} / \mathrm{F}$ and $\mathrm{S} /(\mathrm{A}+\mathrm{F})$ ratios were calculated from the percentages of the oxides $\mathrm{Al}_{2} \mathrm{O}_{3}, \mathrm{Fe}_{2} \mathrm{O}_{3}$, and $\mathrm{SiO}_{2}$. In the $\mathrm{C} / \mathrm{S}$ ratio, the $\mathrm{CaO}$ was corrected for the amount of $\mathrm{CaO}$ com- 
bined with the $\mathrm{SO}_{3}$. In the Lea-Parker ratio [16] the $\mathrm{CaO}$ corrected for the amount combined with the $\mathrm{SO}_{3}$ was divided by the sum of $2.8 \mathrm{SiO}_{2}+$ $1.18 \mathrm{Al}_{2} \mathrm{O}_{3}+0.65 \mathrm{Fe}_{2} \mathrm{O}_{3}$. However, no corrections were made for the free-lime content of the cements.

The following abbreviations and subscripts as defined below will be used in this and other sections of this series of articles.

$W_{1}=$ The amount of water used for normal consistency of the neat cement paste expressed in percentage by weight of the diy cement.

$\mathrm{W}_{2}=$ The amount of water used for standard consistency of the $1: 2.75$ cement to graded Ottawa sand mortars expressed in percentage by weight of the dry cement.

$W_{3}=$ The amount of water used for standard consistency of the $1: 4$ cement to 20-30 Ottawa sand mortars expressed in percentage by weight of the dry cement.

$\mathrm{A}_{3}=$ The air content of the $1: 4$ cement to $20-30$ Ottawa sand mortars of standard consistency expressed in percentage by volume of the mortar.

$\mathrm{S}_{4}=$ The slump in inches of concretes made with a water-cement ratio of 0.635 . (The standard 12in. slump cone was used.)

$\mathbf{A}_{4}=$ The air content of concretes made with a water-cement ratio of 0.635 expressed as a percentage by volume of the freshly made concrete.

$\mathrm{W}_{5}=$ The water-cement ratio (W/C) used for concretes having a $5 \pm 1$-in. slump. The ratio of water to cement was calculated on a weight basis.

$\mathrm{A}_{5}=$ The air content of the concretes having a slump of $5 \pm 1 \mathrm{in}$. expressed as a percentage by volume of the freshly made concrete.

$\mathrm{APF}=$ Fineness in $\mathrm{sq} \mathrm{cm}$ per gram as determined by the air-permeability method.

Wagn $=$ Fineness in $\mathrm{sq} \mathrm{cm}$ per gram as determined by the Wagner turbidimeter method.

Loss= Loss on ignition as determined by standard ASTM and Federal Specifications for portland cement $[6,7]$.

Insol=Insoluble residue as determined by standard ASTM and Federal Specifications for portland cements $[6,7]$.

Alk $=$ Total alkali (expressed in terms of \% $\left.\mathrm{Na}_{2} \mathrm{O}\right)=\% \quad \mathrm{Na}_{2} \mathrm{O}+0.658 \% \quad \mathrm{~K}_{2} \mathrm{O} . \quad\left(\mathrm{Na}_{2} \mathrm{O}\right.$ refers only, to the sodium oxide and does not include the potassium oxide.)

Normal consistency $=$ Term used only for the neat pastes and is defined in ASTM and Federal cement specifications $[6,9]$.

Standard consistency $=$ Term used to describe the $1: 4$ and $1: 2.75$ cement-sand-mortars having flow values on the standard 10-in. flow table as required by ASTM $[10,11]$, and Federal Specifications [6], for these mortars for the air entrainment and strength tests, respectively. (As previously indicated the tolerances of the flow values were chosen less than those specified for standard consistency.)

$\mathrm{NAE}=$ Non-air-entraining cements.

$\mathrm{AE}=$ Air-entraining cements.

$\mathrm{AE}+\mathrm{NAE}=$ Air-entraining plus non-air-entraining cements.

Other symbols for the various dependent variables will be described in the sections where they are used.

In addition, the following statistical terms will be used throughout this Monograph. They will be described more completely in the following section.

S.D. = Standard deviation calculated from the residuals of a fitted equation, or the standard deviation about the average.

s.d.= Estimated standard deviation of the coefficient of an individual independent variable when used in a fitted equation.

Coef./s.d. or Coefficient/s.d.= Ratio of the estimated coefficient (of an independent variable used in an equation) to its estimated standard deviation.

" $F "=$ Fisher's latio of variance estimates. Critical " $F$ " values were obtained from tables presented in most textbooks on statistics. See ref. [18] pp. $6-14$ to $6-16$.

" $t$ " = Student's "t". Critical values were obtained from tables presented in most textbooks on statistics. See ref. [18], pp. 3-23 to 3-26.

\section{Statistical Treatment of the Data ${ }^{2}$}

The data obtained were treated statistically using a digital computer in order to find and evaluate significant relationships between certain properties or the dependent variables and various independent variables, which included chemical composition, minor constituents and trace elements and the interrelation between the properties of the cements and concretes.

This section describes the statistical techniques which will be used in subsequent sections to explore the relationships in the data. The aim has been to explain the procedures used in sufficient detail to serve as an aid in understanding what was done without reproducing in detail material

\footnotetext{
2 References to tables and figures in this section refer to tables and figures in section 2 which follows this section.
}

which is presented better in standard statistical texts. The reader who is uninterested in these procedures or familiar with statistical techniques can, it is hoped, skip the section and still derive an understanding of the relationships which were discussed.

The principal objective of the study of these data was to seek significant relationships between certain dependent variables, such as strengths of mortars and concretes, water requirements, resistance to freezing and thawing damage, etc., and one or more of a large number of independent variables. The independent variables included such properties as chemical composition, amount of air in mortars and concretes, etc.

A second objective consisted of studies of the relationship of the usual laboratory tests, which 
are normally of short duration, to the long-term behavior of cement mortars and concretes.

The main technique used to attain the above objectives was the calculation by least squares methods of the coefficients of regression equations using the dependent variables with one or more independent variables. Standard deviations for the individual coefficients and for the fit of the individual values to the equation as a whole were obtained with each equation, and were used to evaluate the significance of the individual coefficients and of the equation.

The development of multi-rariable regression equations is to some extent a trial and error process. The evaluat or of the data must decide before fitting an equation, first, what the form of the equation shall be (first, second, or higher degree, exponential, etc.), and second, how many and what properties shall be used as independent variables. The initial choice is guided by judgment based on experience with, and knowledge of, the materials and properties involved. In this study various preliminary statistical tests were used as aids in deciding what va riahles and relationships it might be advantageous to try, especially in exploring relationships and variables which had not been adequately investigated previously. Then, after fitting the equation or equations, statistical techniques were used to determine which equations had resulted in meaningful descriptions of relationships, how meaningful, and whether one equation was superior to another in this respect.

In view of the above points, this discussion is divided into three main headings under which the statistical techniques used are described: (1) Preliminary Exploratory Techniques-used in the search for likely relationships and variables, (2) Estimation of Coefficients of Regression Equations-the essential part of the study, which includes both the actual calculation of the estimated coefficients of the equations by least squares methods and the determination of the significance of those coefficients and equations, and (3) Further Exploratory Techniques-used in a search for further independent variables which it might be advantageous to use to improve the significance of an already determined relationship.

\subsection{Preliminary Exploratory Techniques}

The frequency distributions of the values of the different independent variables were determined. The frequency distributions are given in tables (see for example tables 2-1 and 2-2 in the second section of this publication) showing the total number of values included between the limits of various ranges of the values of that variable. Most of these distributions conformed to the normal distribution rather closely. The frequency distribution, grand average, and standard deviation of each of the dependent variables was also determined. The average and standard deviation are helpful in determining the significance of an equation fitted later on.
Using the computer, a large number of plots were made of dependent variables versus each of a series of independent variables and in some cases against different functions of the independent variables, such as the square, square root, logarithm, or their recipıocals. In these plots, instead of plotting all points, the values of the two variables were arranged in descending order of the dependent variable, divided into 12 equal groups, and the average of each group calculated. (If the total number was not an integral multiple of 12 , the remainder was added to the sixth group.) The 12 pairs of averages were then plotted.

Examples of two individual plots as obtained are presented in figures $2-1$ and $2-2$. In figures $2-3$ and $2-4$ the trends of a large number of such plots are sketched in row (2). These sketches show the apparent trend and shape of the relationship. In row (3) of figures $2-3$ and $2-4$, the apparent relationship is further indicated by symbols which are explained in the figure. The numbers and ratios in rows (1) and (4) of figures 2-3 and 2-4 relate to two methods, described below, which were used to evaluate the significance of relationships shown by the plots.

The graphs were divided into four quadrants by a horizontal and a vertical line so that there were equal numbers of points above and below the horizontal line and to the right and left of the vertical line (figs. 2-1 and 2-2). The ratio of the sum of the number of points in one pair of diametrically opposite quadrants to the sum of the number in the opposite pair of quadrants was then determined. (The ratio is always given with the larger number in the numerator.) See figures $2-1$ and $2-2$ and the rows marked (1) in figures $2-3$ and 2-4. A ratio of $6 / 6$ indicates that the 12 points are evenly scattered around the quadrants and there is little if any relationship between the two variables. On the other hand, a ratio of $12 / 0$ indicates that all the points are concentrated in one pair of opposite quadrants, and there is probably a good relationship.

A ratio of odd numbers occurred when the two middle points had the same ordinate or abscissa, and one of the median lines had to be drawn through them instead of between them.

The quadrant ratio criterion mentioned above is a good technique for a rough preliminary examination of plotted points, but is rather insensitive, so far as detection of actual significance is concerned when only 12 points are plotted. In order to obtain a more sensitive criterion, the quadrant sum method proposed by Olmstead and Tukey [17] was used.

The quadrant sum method is applied to the same plots of points divided into quadrants as was used for the quadrant ratio criterion (figs. 2-1 and 2-2). The technique is as follows: The quadrants are designated,,,,+-+- starting in the upper right-hand quadrant and going clockwise in the conventional manner. Then, starting at the righthand side of the diagram, points are counted, pro- 
ceeding to the left, until the next point to be counted is on the opposite side of the horizontal line from the one on which the counting started. The number of points counted is then recorded with the sign of the quadrant in which counting started. For example, in figure 2-1, the point farthest to the right is in the lower right quadrant and is followed by three more below the horizontal line. The fifth point from the right is the single one in the upper right quadrant. The first number recorded is thus -4 . This process is repeated starting from the bottom of the diagram and counting up until the first point is found on the opposite side of the vertical line. (In fig. 2-1 again, the first four points from the bottom are all in the lower right quadrant and the fifth is in the lower left, resulting in another count of -4 .) The process is repeated starting at the left and counting to the right, and starting at the top and counting down. The algebraic sum of the four numbers thus obtained is the quadrant sum. In figure $2-1$, the sum is $(-4)+(-4)+(-3)$

$$
+(-2)=-13 \text {. }
$$

A quadrant sum with an absolute value of 11 or greater has a probability of occurrence of 5 percent in a random distribution of points, and is taken as evidence (at the $95 \%$ confidence level) that a random distribution does not exist, and that there is a significant relationship between the two variables. In figures $2-3$ and $2-4$ quadrant sums for the plots are given in the row marked (4).

Apparent linearity or curvature of the plots is also indicated by the sketches in figures $2-3$ and 2-4. This information was used to indicate possible functions of the independent variable which might be tried in the relationship.

\subsection{Fitting of Regression Equations}

There are a number of standard procedures for fitting equations by the method of least squares. These procedures will not be gone into here. The interested reader may refer to references [18] and [19] or any standard text on least squares or curve fitting.

The equations rere developed in this study by means of a digital computer program, which permitted the fitting of up to 13 independent variables in one equation, without which the amount of labor involved would have been prohibitive. The output from the computer for a given equation consisted of the estimated coefficients for all independent variables (including a constant term), and estimated standard deviations for these coefficients and for the fit of the individual values to the equation as a whole. ${ }^{3}$ Also included were a list of all the deviations of the observed values from the fitted equation; an " $F$ " value, ${ }^{4}$ which indicated the significance of the fitted equation;

\footnotetext{
${ }^{3}$ Coefficients, standard deviations, etc., calculated from data are, in theory, estimates of a true but unknown population parameter. They should be so understood throughout, although the adjective "estimated" is sometimes omitted.

"The " $F$ " value is the ratio of the reduction in variance due to the fitted constants to the variance obtained from the residuals after fitting the constants. See ref. [18], pp. 6-14 to 6-16.
}

and a list of the estimated standard deviations of all of the calculated values.

The equations are presented by giving the estimated coefficients and standard deviations in tables, such as tables $2-3,2-6,2-10,2-14,2-15,2-19$, and 2-20. For example, (1) in the first line in table 2-3 expresses the relationship of the percentage of water used for normal consistency of neat portland cement pastes $\left(W_{1}\right)$ to four independent variables, viz, air permeability fineness $(\mathrm{APF}), \mathrm{Al}_{2} \mathrm{O}_{3}, \mathrm{CaO}$, and $\mathrm{SO}_{3}$. Equation 2 in the same table was fitted using the same data as in eq (1) but with five more independent variables included, viz, total alkali, copper, phosphorus, zirconium, and strontium oxide. These equations could be written as follows:

$$
\begin{gathered}
\mathrm{W}_{1}=4.58+0.00139 \mathrm{APF}+0.233 \mathrm{Al}_{2} \mathrm{O}_{3}+0.196 \\
\mathrm{CaO}+0.824 \mathrm{SO}_{3}
\end{gathered}
$$

and

$$
\begin{aligned}
\mathrm{W}_{1}= & 2.07+0.00144 \mathrm{APF}+0.307 \mathrm{Al}_{2} \mathrm{O}_{3}+0.230 \\
& \mathrm{CaO}+0.776 \quad \mathrm{SO}_{3}+0.546 \mathrm{Alk}-33.8 \mathrm{Cu} \\
& -2.58 \mathrm{P}+6.62 \mathrm{Zr}-1.54 \mathrm{SrO} .
\end{aligned}
$$

Beneath each coefficient in the table is given the estimated standard deviation (s.d.) of that coefficient as calculated from the data. These standard deviations are estimates of the error of the coefficients. For the number of values involved in most of the equations in this study an approximate 95 percent confidence interval for a coefficient may be obtained by multiplying its standard deviation by two. Thus, if the coefficient is greater in absolute value than twice its standard deviation, one may make the assumption that there is a 95 percent probability that that coefficient differs from zero, and therefore, that the independent variable associated with that coefficient has a significant effect on the dependent variable in the equation. Note that all the coefficients in eqs (1) and (2) except the two constant terms and alkali and $\mathrm{SrO}$ in eq (2) meet this criterion of significance.

Since the work of this study was largely exploratory in nature, a variable was generally eliminated from consideration in subsequent equations only if its coefficient in a given equation failed to equal or exceed one times the standard deviation of that coefficient, although this indicates only about a 70 percent confidence in the estimate of the coefficient. One of the reasons for doing this was that addition of other variables to an equation, or other changes, usually changed the ratio of coefficient to standard deviation for variables which were included in both the equations. For example, in eq (5), table 2-3, CaO has a coefficient of 0.131 which is less than two times its estimated standard deviation of 0.079 . However, in eq (6) in the same table, where five other independent variables have been included with the previous four variables, the coefficient for $\mathrm{CaO}$ is about the same as two times its s.d. 
The last column in the tables of equations gives the estimated standard deviation of the equation as a whole under the heading S.D. As mentioned previously, in all the papers of this series the convention is followed of using s.d. to designate standard deviation of an individual coefficient and S.D. for standard deviation of a fitted equation or of the values of a single variable. The S.D.'s for values of the dependent variables are given in notes at the bottom of the tables of equations. The latter were calculated, by the standard formula, using the sum of squares of the deviations of all the values of the variable from the grand average. The S.D. for a fitted equation was obtained, in an analogous manner, from the sum of squares of the deviations of the observed values from the corresponding values calculated using the fitted equation. In table $2-3$, S.D. for eq (1) is 1.149 compared to an S.D. of 1.494 for the 180 values of water for normal consistency. This is a highly significant reduction in standard deviation gained by fitting an equation with four independent variables. In eq (2) a further reduction to 1.045 has been achieved by fitting five more coefficients. This is also a highly significant reduction.

In cases where an equation is fitted with one set of variables, and a further reduction of the estimated standard deviation is obtained by fitting one or more additional variables with the same original set, it is possible to assess the significance of the reduction statistically. This was done for all such pairs of equations given in tables $2-3,2-6$, $2-10,2-15$, and $2-20$, and the results are presented in table $2-22$. The " $F$ " ratio ${ }^{5}$ given in column 3 of table 2-22 must exceed the Critical " $F$ " ratio in the last column for the reduction to be significant at the 95 percent level and the critical " $F$ " ratio in the next to the last column to be significant at the 99 percent level.

Another technique that was used to check on the reliability of a fitted equation was to develop two more equations with the same dependent and independent variables, but using in the first one only the odd numbered values from the array used in calculating the coefficients for the original equation and the even numbered values in the second one. This is illustrated by eq (2) in table 2-3, calculated from values from 180 cements, and eqs $(2 \mathrm{~A})$ and $(2 \mathrm{~B})$ each calculated from 90 , or half the original set. These equations were compared and if the coefficients of the "odds" and "evens" are in close agreement, the confidence which can be placed on the relationship is enhanced. There were a number of cases in which an estimated coefficient was larger than its s.d. in the complete set but smaller in one of the reduced sets, as in the case of alkali in eqs (2) and (2A), table $2-3$. However, this usually happened only in cases where the coefficient for the complete set was near the borderline of significance. It occurred in very

\footnotetext{
5 "This " $F$ " ratio is the ratio of the reduction in variance due to the additional fitted constants to the variance obtained from the residuals after fitting all the constants. See ref. [18], pp. 6-14 to $6-16$.
}

few cases where the original coefficient was more than two times its s.d. If the equations were not in agreement studies were made of the individual values to determine if one $01^{\circ}$ more of the cements was very different in some respect.

In all cases equations were fitted for a dependent variable and a set of independent variables using all the cements $(\mathrm{AE}+\mathrm{N} \Lambda \mathrm{E})$, without respect to type classification and then a second equation using only the non-air-entraining cements (NAE), again without respect to type classification (table 2-3, eqs (1) and (2) for example). Equations were not developed with the AE cements alone because there were too few of them to give a significant result, and because of this, inclusion or $\mathrm{ex}$ clusion of the $\mathrm{AE}$ cements made little difference in the results in most cases, unless air content was an important independent variable.

The number of cements represented in the equations varied, as may be seen from the tables, due to a number of reasons. Three white portland cements were, because of their vely low iron contents, excluded from many of the statistical studies. Also one or more test values were missing from some of the variables for one reason or another, and when a test value was missing from one variable in a set being considered, data for that cement had to be eliminated from all the other variables being used. Generally in developing any series of equations, such as all those in table 2-3, all cements which had missing values in any of the variables to be used throughout the set were eliminated before fitting any of the equations. Thus each equation in the set was based on data from the same list of cements and could be compared with more confidence to any other in the same set.

Minor constitutents were not determined on all of the cements. In cases where these were used as independent variables, therefore, the elimination of cements with missing values resulted in equations which were based on 170 to 180 cements when both air-entraining and non-air-entraining cements were used, and about 160 to 165 when only the non-air-entraining cements were used.

There were cases in this investigation in which some of the values for some of the variables appeared far out of line with the other values and no satisfactory explanation could be determined other than possible error in testing or in transcribing of test values. In this study, cements which had a value for a variable which differed from the average by more than four times the standard deviation of all values of that variable, were generally deleted from consideration if a study of the test results of that cement indicated nothing else unique with respect to its properties.

For some equations, the apparent contribution and range of contribution of the independent variables to the dependent variables were computed. (See table 2-4.) This was done by multiplying the upper and lower values for each variable (col. 2) by the coefficient for that variable (col. 4) to give the calculated contributions in col. 5 . The 
ranges in col. 6 are the differences between the two values in col. 5. It must be emphasized that these are not exact values, but only indications estimated from the equations calculated from the data of this study. For these computations, an equation including the trace elements and having a low S.D. value was usually chosen. Different values may readily be derived from other equations presented in the tables.

\subsection{Further Exploratory Techniques}

Once an equation was developed with a given dependent variable and a certain basic set of independent variables and with estimated coefficients significantly larger than their estimated standard deviations, the question then arose, would this relationship be improved by including others of the large number of available independent variables in the same relationship. In particular it was desirable to investigate the effect of the relationships of the minor and trace elements which were determined in this study but are not usually determined in cement analyses.

One method of exploring the contribution of these other variables would be the trial and error method of fitting new equations, adding the other variables singly and in various combinations. And indeed, the final test of whether a new variable or combination of variables had a significant effect was to fit it in the equation and observe whether a significant reduction in S.D. and significant ratios of coefficient to s.d. for the new variable occurred, together with no loss of significance for the other coefficients in the equation.

The trial and error method is a time-consuming process, however, and in order to explore the remaining variables in a search for likely ones to fit in the equations, two statistical techniques were used. Both of these techniques were based on the following assumption. If a given independent variable has no functional relationship to the dependent variable in a given equation, then the distribution of the values of the independent variable should be random with respect to the distribution of the deviations from the fitted equations. The deviations from an equation are obtained by subtracting from the observed values of the dependent variable, the calculated values obtained by substituting in the equation the sets of observed values of the independent variables corresponding to each observed value of the dependent variable. If the equation exactly fitted all the observed values, of course, all the deviations would be zero and the S.D. for the equation would be zero. This never happens in any practical case, however, and the deviations that occur are compounded of two elements, (1) the irreducible random error of the testing procedure, and (2) the effects, if any, of other independent variables which were not included in the equation.

If the distribution of the values of the variable is random with respect to the deviations, then there should be no significant difference between the average of values of the new variable for cements associated with large positive deviations and those associated with large negative deviations, for instance. On the other hand, such a difference should exist if the new variable is in part responsible for the deviations in the equations.

The first method used for exploring the situations described above employed the standard Student's " $t$ " test for a significant difference between averages. See ref. [18], pp. 3-23 to 3-26. In this method the cements which were responsible for the 20 positive deviations of the greatest magnitude, the 20 with the negative deviations of greatest magnitude, and the 20 with deviations in the middle of the distribution (closest to zero in most cases) in a fitted equation were determined. Then for the values of each other independent variable to be examined, two comparisons were made as follows: (1) The average of the values for the 20 cements from the large positive deviation group was compared to the average value of the 20 from the large negative deviation group. Since the ones with the largest positive deviations are those which are highest with respect to the corresponding values calculated from the equation, and those with the greatest negative deviations are those which are lowest with respect to the calculated values, this is called in what follows the "highlow comparison." (2) The average of the large positive and large negative deviation groups together was compared to the average of the 20 from the middle group. This is called the "middle-ends comparison." A significant difference in the highlow comparison indicates that the variable under consideration may be correlated with the deviations from the equation being studied, and it may be fruitful to include it as an additional independent variable in that operation. A significant difference in the middle-ends comparison leads one to suspect the existence of a nonlinear relationship between the independent variable and the dependent variable in the equation. In many cases, such as eqs (1) and (2) in table 2-3, the additional variables to add to the original equation were selected in this manner.

In both comparisons the " $F$ " test for determination of a significant difference between variances [18] was used to determine whether the variances of the two groups of values were sufficiently alike to make the " $t$ " test valid. The independent variables tested by these techniques included the oxides, some of the chemical ratios, and all determined minor and trace elements which are listed in a following article.

The " $t$ " test for a significant difference between averages used in the method described above is sensitive to a single unusually large value in one of the groups compared. Another difficulty, peculiar to this study, was that for many of the minor constituents or trace elements, there was an appreciable number of zeros in the data. This did not always mean that the element was nonexistent in those cases, but it was beneath the lower limit re- 
ported. It sometimes happened that in one or more of the groups of 20 the majority of the values were zero. These and other considerations caused anomalous results in some instances.

For the above reasons another technique was used which had the advantage of examining all the values of a variable instead of only three groups of 20 and which was not affected by single large values. In this method (table $1-5$ ) all the values of a variable which were not zero were tallied on a 3 by 3 grid according to whether they represented a cement with a high, medium, or low deviation in the given equation ${ }^{6}$ and whether they were in the high, middle, or low third of the distribution of values for the variable. In addition the zero values which corresponded to high, middle, and low deviations were tallied and the row sums for the nonzero values determined. Proportions in each category were also calculated. This test was dubbed the "tic-tac-toe" test because of the resemblence of the grid to the old-fashioned game.

As an aid in assessing the meaning of these "tic-tac-toe" distributions, a chi-square statistic was calculated for each one. One of the uses of the chi-square test [21] is to measure conformance of an observed distribution with some expected distribution. $^{7}$ In our case the assumption is that the values of the independent variable in question are randomly distributed with respect to the deviations from the equation and therefore the numbers tallied in the nine cells of the grid should be approximately equal and the numbers of zeros should be divided in thirds. (The chi-square is calculated only for the distribution of nonzero values.) Any significant departure from the expected uniform distribution represents evidence that there is some relationship between the variable and the deviations and causes an increase in chisquare.

Table 1-5 shows a sample printout from the computer program which was used to calculate the "tic-tac-toe" distribution, chi-square, high-low comparison, and middle-ends comparison for any chosen variable and the deviations from a chosen equation. (This particular evaluation was for lotal alkali as an independent variable compared to the deviations from an equation using 24-hr shrinkage on drying and was developed for a later article in this series.) In this example there did not happen to be any zero values for the independent variable (alkali) and the expected number in each cell of the 3 by 3 alray would be between 17 and 18, one-ninth of the total number of 158. Note that the number is consiclerably higher than expected in three cells along one diagonal of the array, indicating that high values of alkali were associated with observed values of expansion above those calculated from the equation, and low values of alkali were associated with the large negative deviations. The chi-square of 19.9 is significant at the 95 percent level. The " $t$ " values for the high-low and middle-ends comparisons, however, did not show any significance in this case.

Evidence of significance from either the " $t$ " test, the "tic-tac-toe" or chi-square tests was used in selecting additional independent variables to be added to already fitted equations. If the additional independent variable did not meet the criteria used it was not included in the reported relationships.

\begin{tabular}{l} 
TABLE 1-5. $\begin{array}{c}\text { 24-Hour shrinkage versus total alkali } \\
\text { Number of values=158 } \\
\text { Number not zero=158 }\end{array}$ \\
\hline \hline Deviations \\
\hline
\end{tabular}

Chi square $=19.92$.

Hi-lo comparison ( 19,19 D.F.), “t” $=0.0135$, ratios of variances $=1.090,0.918$. Middle-ends comparison $(38,19$ D.F.), " $t$ " $=-0.272$, ratios of $\nabla$ ariances $=$ $1.892,0.529$.

\section{Limitations on Interpretation of Statistical Studies}

Some of the problems associated with the statistical analysis of a large amount of data as developed in this program have been dealt with in the introduction. It was pointed out that these studies were exploratory in nature and that the statistical devices had varying degrees of power and sophistication. In the preceeding subsection the various statistical techniques used were described and some of their limitations noted. Further limitations and problems associated with the interpretation of the results are presented in this subsection.

Plotting the dependent variable and various single independent variables using the averages

\footnotetext{
${ }^{\circ}$ In this context high, medium, and low refer respectively to the upper, middle, and bottom third when the deviations are ranked in order from greatest positive to greatest negative.

See ref. [21], pp. 174-179.
}

of the 12 groups as previously indicated, provided a simple graphic method of presentation of the trends involved. The quadrant ratios and quadrant sums were computed in order to further evaluate these trends and to indicate which variables should be used in an equation. However, there. were, as will be noted in the following sections, many discrepancies between the results of these evaluations and the more sophisticated least squares method used to evaluate the combined effects of a number of variables. For example, in section 2 on water requirements, eq (2) of table 2-14 and figure 2-2 represent relationships between the same pair of variables. Figure 2-2, however, appears to indicate a definite curvature, while eq (2) is linear, and if plotted on the coordinates 
of figure 2-2 would not appear to fit the plotted 12 points. This apparent discrepancy is due to several characteristics of the data such as: (1) The scatter of the individual points, which causes uncertainty in the coefficients of an equation developed for all of them, (2) the method of averaging used in developing the plots, and (3) the narrow range of the values of the variables, which results in a small difference in shape between a linear plot of the variables and, for instance, their squares. A second-degree equation developed with these two variables did not show increased significance over the linear one.

Thereas some of these discrepancies may be caused by factors which will be discussed later in connection with individual cases, some may be caused by an independent rariable having a predominant effect. In the examples presented from the following sections on water requirements, the air-entraining characteristic is such a property and there were only 14 cements classified as $\mathrm{AE}$. The effect is shown in frequency distribution values, in the S.D. values as well as in the comparable equations computed for the $\mathrm{AE}+\mathrm{NAE}$ and the NAE cements. Such effects are more pronounced in the case of some properties than in others. It appeared desirable, even though equations could not be computed for the $\mathrm{AE}$ cements by themselves, to include them with the computed equations for the NAE cements. In addition, the equations were also computed for the NAE cements.

In any statistical studies of this nature, the empirical equations are dependent on the adequacy of sampling of the population, in this case, all portland cements. In an attempt to obtain a representative sampling, cements of the different types and from as large an area as possible were included. The chemical analyses indicated fairly normal distributions of most of the oxides determined. As indicated previously in discussing the effect of air entrainment, a normal distribution is not always attained with all properties. The comparisons of the coefficients for the different independent variables of the "odds" and "evens" in an array of cements (assuming representative sampling) afforded a greater confidence in the equations when the coefficients were in close agreement. Conversely, when discrepancies did occur, as was the case with some variables having coefficients of marginal significance, the need for further studies of those variables was indicated. Some of the anomalies noted may have resulted from the chance occurrence of two or more extreme values of a variable in one of the two groups. Other anomalies may have resulted from the method of treatment of the trace elements many of which had values below the reporting limit and were listed as having a zero quantity. In some instances only a few of the cements had reported values for some of the trace elements.

Certain other difficulties and problems related to the nature of portland cement are encountered in the interpretation of equations such as those derived and presented in the following sections. Some problems result from the leeway permitted, for example, in water used for normal consistency of pastes and mortars and to the large variability associated with the test methods. The lack of information of some of the variables also limited the attainment of better relationships. Still other problems arise from the interaction or interdependence of some of the nominally independent variables.

Some of the quantities measured are quantities which have been closely controlled in the manufacture of the cement, usually because of specification limits or because experience has shown that they have a large effect on the finished product. The range of values of such a quantity when used as one of the variables in an equation may, therefore, be insufficient to show the relationship between that variable and some other property of the cement or concrete used as a dependent variable. If the range of values of an independent rariable is further limited by computing an equation for only one of the five types of cement, for example, it may be expected that the reliability of the estimate of the coefficient of a variable would be less than if a broad range of a cement property is used in computing the equation.

The nature of the composition of portland cement is such that there may be a relationship between certain so-called independent variables. For example, the degree of correlation between the $\mathrm{C}_{3} \mathrm{~S}$ and $\mathrm{C}_{2} \mathrm{~S}$ in a series of portland cements may be very high. Also, the $\mathrm{Al}_{2} \mathrm{O}_{3}$ content and calculated $\mathrm{C}_{3} \mathrm{~A}$ are related as are other compounds and oxides. If there are correlations, such as exists here, between some of the variables in a multirariable relationship, the equations are not necessarily invalidated, but the contribution of individual independent variables to the dependent variable cannot be considered apart from the contribution of others. Previous studies on pure compounds and on cements in which attempts have been made to increase or decrease one variable at a time have fairly well established the roles of the principal variables. Equations such as those developed in this study may, however, serve a useful purpose in predicting certain properties or longterm behavior.

The fact that the number of cements involved in the study was large and that at least semiquantitative values were obtained for the minor constituents permit us to gain some information relative to the relationship of the latter to cement or concrete properties. More precisely determined values are needed both for the minor constituents or trace elements and the test results in general. However, the fact that some of the minor constituents appear to have a significant relationship to properties of interest may indicate that further studies of the effect of these elements may be desirable and fruitful.

No information was available on the tempera- 
ture of the clinker formation, the amount of liquid formed, the oxidizing or reducing conditions of burning, nor the rate of cooling of the clinker, all of which are recognized as affecting the properties of portland cement. In some cases it might have been possible to obtain lower S.D. values by the inclusion of some of these variables if knowledge of them had been available.
Another factor which is probably involved in the lack of better or more definitive equations is the presence of materials other than calcium sulfate in the gypsum used in the portland cements. Such materials could affect the calculated compound composition values in that the chemical analysis of a centent may differ from that of the clinker from which it was made.

\section{Summary and Conclusions}

This first section has presented general information on the cements, concretes, and tests conducted as well as the statistical techniques used throughout and referred to in subsequent sections dealing with specific aspects of the interrelations between cement and concrete properties.

The 199 portland cements of the various type classifications were procured mostly from different areas of the United States with only a few from overseas and are believed fairly representative of portland cements manufactured at the time of procurement.

The tests made on the cements and concretes have been enumerated and in some instances, where the tests and test methods were related to various aspects of the study, the methods used have been described and will be referred to in subsequent sections. Various exploratory techniques used to determine the variables associated with the various properties have been described.

Various techniques were employed in determining and assessing the value of independent variables associated with the different properties. The greatest importance was given to computed multiple regression equations with means for evaluating the significance of the different variables and combinations of variables employed.

After developing an equation with a group of significant independent variables, additional equations using the same variables were computed for the "odds" and "evens" in the array of cements.
When the coefficients for the "odds" and "evens" were in agreement confidence in the relationslips was enhanced.

Some of the limitations relative to the statistical interpretations of the results have been presented and discussed. Examples of the various techniques used have been presented to indicate their usefulness as well as their limitations.

The techniques described here may be of help to others faced with the problem of evaluating large masses of experimental data.

Acknowledgments are made to the heads of branch laboratories of the National Bureau of Standards at Allentown, Pa., Denver, Colo., San Francisco, Calif., and Seattle, Wash., G. Stiller, O. H. Cox, O. C. Marek, and Frank Wimblade, respectively, as well as their associates and coworkers and to M. R. DeFore, Leonard Bean, and R. A. Clevenger and associates in the Washington laboratory for collecting the cements and making the many tests involved. Acknowledgments are also made to D. N. Evans for collecting, checking, and compiling the data. Special acknowledgments are made to W. J. Youden and J. M. Cameron of the statistical engineering section and to members of the computer section for assistance in planning the investigation and for suggestions and advice relative to methods of analyzing the data.

\section{References}

[1] Chemistry of Cement, Proceedings of the Fourth International Symposium, National Bureau of Standards Mono. 43, Vol. 1, 2, Aug. 1962, U.S. Government Printing Office. Washington, D.C.

[2] Proceedings of the Third Intelnational Symposium on the Chemistry of Cement, London 1952, Cement and Concrete Association, London.

[3] R. H. Bogue, The Chemistry of Portland Cement, 2d edition (Reinhold Publishing Corp., 1955).

[4] F. M. Lea and C. H. Desch, The Chemistry of Cement and Concrete, revised edition, Edward Arnold (Publishers) Ltd., 1956.

[5] Standard Specifications for Portland Cement, ASTM Designation C 150-62.

[6] Federal Specification SS-C-158c Amendment 1; Cements, Hydraulic, Methods for Sampling, Inspection and Testing, May 25, 1954.

[7] Standard Methods of Chemical Analysis of Portland Cement, ASTM Designation C 114-53.
[8] J. J. Diamond, Photometric determination of strontium in portland cement, Anal. Chem. 27, 913, June 1955.

[9] Standard Method of Test for Normal Consistency of Hydraulic Cement, ASTM Designation C 18755.

[10] Tentative Method of Test for Air Content of $\mathrm{H}_{5}$ draulic Cement Mortar, ASTM Designation C $185-53 \mathrm{~T}$.

[11] Tentative Method of Test for Compressive Strength of Hydraulic Cement Mortars (using 2 in. cube specimens) ASTM Designation C 109-54T.

[12] Standard Method of Test for Slump of Portland Cement Concrete, ASTM Designation C 143-52.

[13] Standard Method of Test for Weight per Cubic Foot, Yield and Air Content (Gravimetric) of Concrete, ASTM Designation C 138-44.

[14] Federal Specification SS-C-192a, Cements, Portland, July 2, 1956. 
[15] Standard Specifications for Portland Cement, ASTM Designation C 150-53.

[16] Reference 4, page 158 .

[17] Paul S. Olmstead and John W. Tuker, A corner test for association. Ann. Mat. Statistics 18, 495, (1947).

[18] M. G. Natrella, Experimental Statistics, NBS Handbook 91, Aug. 1, 1963, U.S. Dept. of Comm., NBS, U.S. Government Printing Office, Washington, D.C.
[19] R. T. Anderson and T. A. Bancroft, Statistical Theory in Research (McGraw Hill Book Co., Inc., New York, N.Y., 19.22).

[20] W. J. Dixon and F. J. Massey, Jr., Introduction to Statistical Analysis, 2d Edition (McGraw Hill Book Co., Inc., New York, N.Y., 1957).

[21] Sidney Siegel, Non Parametric Statistics for the Behavioral Sciences (McGraw Hill Book Co., Inc., New York, N.Y., 1956). 


\title{
Section 2. Water Requirements of Portland Cement
}

\author{
R. L. Blaine, H. T. Arni, and R. A. Glevenger
}

\begin{abstract}
The relationship between cement characteristies and the water requirements of neat cement pastes, mortars, and concretes made with 199 portland cements of different types and from various areas were studied by fitting multivariable regression equations with the aid of a digital computer. The principal variables which appeared to have the greatest effect on water requirements were as follows: (1) For neat cement pastes of normal consistencyfineness; (2) for the $1: 4$ and $1: 2.75$ mortars of standard consistency - the air content, $\mathrm{Al}_{2} \mathrm{O}_{3}$, and silica modulus; (3) for concretes - the air content, $\mathrm{Al}_{2} \mathrm{O}_{3}$, and $\mathrm{Fe}_{2} \mathrm{O}_{3}$. The use of $\mathrm{A} / \mathrm{F}$ ratios or the potential $\mathrm{C}_{3} \mathrm{~A}$ values in place of the $\mathrm{Al}_{2} \mathrm{O}_{3}$ values in the computations resulted in concordant equations. Other commonly determined variables as well as a number of the minor constituents and trace elements also appeared to be associated with the water requirements to a lesser degree.
\end{abstract}

\section{Contents}

1. Introduction

2. Portland cements and concretes

3. Statistical treatment of data $\ldots \ldots \ldots$

4. Results of tests

4.1. Chemical analyses and fineness of portland cements _............... 14

4.2. Water requirements of neat portland cement pastes...

4.3. Water requirements of $1: 2.75$ cement to graded Ottawa sand mortars _... 15

4.4. Water requirements for 1:4 cement to standard Ottawa sand mortars _...

4.5. Concrete made with a constant water-cement ratio

4.6. Con crete with a slump of $5 \pm 1$ inches

4.7. Calculations on high- and low-air cements

5. Discussion__-

6. Summary and conclusion

\section{Introduction}

It has long been recognized that the water requirements necessary to produce comparable consistency, workability or placeability for neat pastes, mortars, or concretes differ to some extent with different cements. Cognizance has been given to this property in Federal $[1]^{1}$ and ASTM specifications $[2,3,4]$ by providing that different amounts of water be used with different cements for the neat cement pastes of normal consistency required for time of set and autoclave tests, as well as different amounts of water with different cements for the mortars of standard consistency used for the laboratory acceptance tests, for strength and other properties. The use of different water percentages with different cements in the laboratory acceptance tests has been justified because of the relationship of those water-cement ratios to the water requirements of concretes. However, the degree of correlation of water requirements of pastes and mortars with that of concrete has often been questioned. Also, different laboratories have exhibited some difficulties in obtaining satisfactory agreement with respect to the water requirements for the standard test mortars which, in turn, may lead to variations in test results. Because of such difficulties, proposals have been made that better interlaboratory correlation of strength test results would be obtained if a constant water-cement ratio were used in the

\footnotetext{
1 Figures in brackets indicate the literature references at the end of this paper, p. 32 .
}

laboratory acceptance test mortars. For example, the tentative specification, ASTM Designation C109-43T, later withdrawn, required the use of 53 percent water with all cements in the $1: 2.75$ cement to graded sand mortar. It was reported [5] that, with air-entraining cements, flows of such mortars on the standard 10 -in. flow table ranged from 120 to more than 150 percent. ${ }^{2}$ Other specifications such as those developed and proposed by Cembureau and RILEM which are used in some countries also require the use of a mortar with a constant water-cement ratio.

Although many articles have been published relative to water requirements of cements and concretes, previously unpublished but relevant information on this subject obtained as a part of this study of various interrelations between cement and concrete properties is presented. It seemed that with the large amount of data available it would be possible to determine some of the factors which may contribute to such variations. This section, which is one of a series on the study of interrelations between cement and concrete properties, deals primarily with the subject to water requirements of different cements in the different test-mortars and concrete. However, the influence of air contents of the different mixtures will also be considered.

${ }^{2}$ A pertinent discussion relative to this article was presented by
Abrams [7]. 


\section{Portland Cements and Concretes}

The number of portland cements of the various types and the areas from which they were procured have previously been presented, together with the test methods used for chemical analyses and for determining the water requirements of the neat pastes and mortars [6]. Also presented in the first section in this publication were the descriptions of the aggregates and the proportions of the concretes, together with the mixing procedures and specification methods used for determining slump and air content.

The cements in this investigation were classified as AE or NAE on the basis of the air contents of the $1: 4$ mortars in effect at the time the tests were made. ${ }^{3}$

\section{Statistical Treatment of Data}

The data obtained for the water requirements for the different cements were treated statistically as presented in the first section of this publication [6]. Briefly this consisted of computing multivariable regression equations to indicate the relationships between dependent and commonly determined independent variables as well as the minor constituents and trace elements. Various statistical techniques as previously described [6] were used to determine the independent variables involved. Equations of special significance to the water demands are presented together with calculated ranges of contributions of the various independent variables of selected equations. Some of the limitations of the statistical methods as applied to these studies have previously been discussed [6].

Equations were computed for the $\mathrm{AE}+\mathrm{NAE}$ and for the NAE cements. Other equations were also computed for cements with less than 7.0 percent air as determined by the $1: 4$ mortar test, and for cements having 7.0 percent or more air when determined by this test.

\section{Results of Tests}

\subsection{Chemical Analysis and Fineness of Portland Cements}

The frequency distributions of the cements with respect to chemical composition, calculated potential compound composition, and fineness as determined by the air permeability method and the Wagner turbidimeter are presented in table $2-1$. In most instances, a considerable range of oxide composition is indicated. This was also true for the calculated compound composition values and for the fineness values as determined by the two methods.

\subsection{Water Requirements of Neat Portland Cement Pastes}

In table 2-2 are presented the frequency distributions of the cements with respect to the amount of water used for normal consistency of the neat cement pastes. The average percentage water used for normal consistency was 24.70 for the group AE+NAE cements, 24.67 for the group NAE cements by themselves, and 25.12 for the 12 $\mathrm{AE}$ cements. The standard deviation for both the AE+NAE and NAE cements was 1.494.

Presented in table 2-3 are relationships of various independent variables to the amount of water used with these pastes. ${ }^{4}$ Equation 1, computed for the AE + NAE cements using four of the commonly determined variables, has an S.D. of 1.149. Equation 2 shows the result of adding, to the set of the original four variables, five of the minor or trace elements shown by the high-low and middle-ends comparisons to be associated with water requirement. The reduction of the S.D. from 1.149 to 1.045 is highly significant, as shown by the " $F$ " test in table 2-22. Using the independent variables of eq (2) and computing the relationship for the "odds" and "evens" in the array of cements, the coefficients of eqs (2A) and (2B) in table 2-3 were obtained. (See Statistical Treatment of the Data [6].)

When the equations were computed for only the NAE cements using the same four commonly determined variables, the relationship indicated in eq (3) of table 2-3 was obtained. Inclusion of the minor and trace elements again produced a significantly lower S.D. value as indicated in eq (4). (See also table 2-22.) Computing with the "odds" and "evens" in the array of these cements resulted in eqs (4A) and (4B). The reasons for some of the anomalies in the "odds" and "evens" have previously been discussed [6].

In eqs (5), (6), (9), and (10) the $\mathrm{A} / \mathrm{F}$ ratio was used instead of the percentage of $\mathrm{Al}_{2} \mathrm{O}_{3}$, and in

\footnotetext{
3 The upper specification limit for air content of NAE cements was originally set in early specifications at 8.0 percent in the $1: 4$ mortar and in later specifications it was raised to 12.0 percent. The specification limits for air content of the AE cements in the early specifications were 12 to 20 percent, content of the AE cements in the early specifications were 12 to 20 percent, then $18 \pm 3$ percent (in effect at the time these tests were made), and later
raised to $19 \pm 3$ percent. Two cements having air contents in the 12 to 15 raised to $19 \pm 3$ percent. Two cements having air contents in the 12 to 15
percent range when tested in the $1: 4$ mortar were included with the NAE cements.

$₫$ The equations in this and other tables in this section were selected from more than 1,000 trial equations on the basis of interest and relevancy to the study. See first section of this paper [6] for nomenclature.
} 
eqs (7), (8), (11), and (12) the $\mathrm{C}_{3} \mathrm{~A}$ values were used instead of the $\mathrm{Al}_{2} \mathrm{O}_{3}$. When the $\mathrm{A} / \mathrm{F}$ ratio or the $\mathrm{C}_{3} \mathrm{~A}$ were used as variables other changes such as the use of $\mathrm{CaO}$ or $\mathrm{C}_{3} \mathrm{~S}$ as independent variables were found necessary in order to attain the lower S.D. values. The S.D. values for both the $\mathrm{AE}+\mathrm{NAE}$ and the NAE cements were not greatly different from those where the $\mathrm{Al}_{2} \mathrm{O}_{3}$ was used in the equations. In each instance the addition of certain minor constituents or trace elements resulted in significantly lower S.D. values than when only the commonly determined variables were used (table 2-22).

Regularly conducted interlaboratory tests on another series of cements over a period of two years by the five laboratories that made tests in the present study indicated a characteristic standard deviation of 0.66 percent for water used for normal consistency of neat pastes. The values for S.D. obtained in the present study were considerably higher, indicating that some further source of variation (possibly the wide variety, or some false setting cements, for instance) was present in these tests

Using approximate ranges of values of the independent variables presented in table $2-1$ and the coefficients of eq (2) of table 2-3, the calculated contributions to the amounts of water used for normal consistency of the neat cement pastes, $W_{1}$, are presented in table 2-4. Also presented in this table are the ranges of the computed values.
These computations assume that for changes in each of the independent variables, all of the other variables are held constant.

\subsection{Water Requirements of $1: 2.75$ Cement to Graded Ottawa Sand Mortars}

The frequency distribution of the different cements with respect to the percentage water used for the 1:2.75 cement to graded Ottawa sand mortars of standard consistency is presented in table $2-5$. There was a considerable overall range of values for the different cements. There was also an overlapping of the water requirements for the different types of cement, although the air-entraining cements tended to occur in the lower part of the distribution curve whereas the highest values were obtained with some of the type I cements.

The average amount of water used for standard consistency was 48.24 percent when the $\mathrm{AE}+\mathrm{NAE}$ cements were considered, 48.39 percent when only the NAE cements were considered, and 46.16 for the $12 \mathrm{AE}$ cements. The respective values for standard deviation were 1.402 and 1.281 percent for the $\mathrm{AE}+\mathrm{NAE}$ and NAE cements.

The air contents of the $1: 2.75$ mortar's were not determined, and it was therefore necessary to use the air-content values of the 1:4 cement to standard Ottawa sand mortars normally used in the air-entrainment test, in computing the equations for the relationship between various independent

TABLE 2-1. Frequency distribution of cements with respect to chemical composition and fineness

\begin{tabular}{|c|c|c|c|c|c|c|c|c|c|c|c|c|c|c|c|c|}
\hline \multirow[t]{2}{*}{$\mathrm{SiO}_{2}$} & Range, \% & $\begin{array}{c}19.0 \\
\text { to } \\
19.5\end{array}$ & $\begin{array}{c}19.5 \\
\text { to } \\
20.0\end{array}$ & $\begin{array}{c}20.0 \\
\text { to } \\
20.5\end{array}$ & $\begin{array}{c}20.5 \\
\text { to } \\
21.0\end{array}$ & $\begin{array}{c}21.0 \\
\text { to } \\
21.5\end{array}$ & $\begin{array}{c}21.5 \\
\text { to } \\
22.0\end{array}$ & $\begin{array}{c}22.0 \\
\text { to } \\
22.5\end{array}$ & $\begin{array}{c}22.5 \\
\text { to } \\
23.0\end{array}$ & $\begin{array}{c}23.0 \\
\text { to } \\
23.5\end{array}$ & $\begin{array}{c}23.5 \\
\text { to } \\
24.0\end{array}$ & $\begin{array}{c}24.0 \\
\text { to } \\
24.5\end{array}$ & $\begin{array}{c}24.5 \\
\text { to } \\
25.0\end{array}$ & $\begin{array}{c}25.0 \\
\text { to } \\
25.5\end{array}$ & & \\
\hline & No. of cts. & 4 & 6 & 20 & 26 & 31 & 33 & 22 & 24 & 13 & 6 & 7 & 5 & 2 & & \\
\hline \multirow[t]{2}{*}{$\mathrm{Al}_{2} \mathrm{O}_{3}$} & Range, \% & $\begin{array}{l}2.5 \\
\text { to } \\
3.0\end{array}$ & $\begin{array}{l}3.0 \\
\text { to } \\
3.5\end{array}$ & $\begin{array}{l}3.5 \\
\text { to } \\
4.0\end{array}$ & $\begin{array}{l}4.0 \\
\text { to } \\
4.5\end{array}$ & $\begin{array}{l}4.5 \\
\text { to } \\
5.0\end{array}$ & $\begin{array}{l}5.0 \\
\text { to } \\
5.5\end{array}$ & $\begin{array}{l}5.5 \\
\text { to } \\
6.0\end{array}$ & $\begin{array}{l}6.0 \\
\text { to } \\
6.5\end{array}$ & $\begin{array}{l}6.5 \\
\text { to } \\
7.0\end{array}$ & $\begin{array}{l}7.0 \\
\text { to } \\
7.5\end{array}$ & $\begin{array}{l}7.5 \\
\text { to } \\
8.0\end{array}$ & & & & \\
\hline & No. of cts. & 4 & 7 & 6 & 30 & 38 & 33 & 30 & 32 & 8 & 10 & 1 & & & & \\
\hline \multirow[t]{2}{*}{$\mathrm{Fe}_{2} \mathrm{O}_{3}$} & Range, \% & $\begin{array}{l}0 \\
\text { to } \\
0.5\end{array}$ & $\begin{array}{l}0.5 \\
\text { to } \\
1.0\end{array}$ & $\begin{array}{l}1.0 \\
\text { to } \\
1.5\end{array}$ & $\begin{array}{l}1.5 \\
\text { to } \\
2.0\end{array}$ & $\begin{array}{l}2.0 \\
\text { to } \\
2.5\end{array}$ & $\begin{array}{l}2.5 \\
\text { to } \\
3.0\end{array}$ & $\begin{array}{l}3.0 \\
\text { to } \\
3.5\end{array}$ & $\begin{array}{l}3.5 \\
\text { to } \\
4.0\end{array}$ & $\begin{array}{l}4.0 \\
\text { to } \\
4.5\end{array}$ & $\begin{array}{l}4.5 \\
\text { to } \\
5.0\end{array}$ & $\begin{array}{l}5.0 \\
\text { to } \\
5.5\end{array}$ & & & & \\
\hline & No. of cts. & 3 & & 1 & 5 & 27 & 48 & 52 & 34 & 15 & 12 & 2 & & & & \\
\hline \multirow[t]{2}{*}{$\mathrm{CaO}$} & Range, $\%$ & $\begin{array}{c}60.0 \\
\text { to } \\
60.5\end{array}$ & $\begin{array}{c}60.5 \\
\text { to } \\
61.0\end{array}$ & $\begin{array}{c}61.0 \\
\text { to } \\
61.5\end{array}$ & $\begin{array}{c}61.5 \\
\text { to } \\
62.0\end{array}$ & $\begin{array}{c}62.0 \\
\text { to } \\
62.5\end{array}$ & $\begin{array}{c}62.5 \\
\text { to } \\
63.0\end{array}$ & $\begin{array}{c}63.0 \\
\text { to } \\
63.5\end{array}$ & $\begin{array}{c}63.5 \\
\text { to } \\
64.0\end{array}$ & $\begin{array}{c}64.0 \\
\text { to } \\
64.5\end{array}$ & $\begin{array}{c}64.5 \\
\text { to } \\
65.0\end{array}$ & $\begin{array}{c}65.0 \\
\text { to } \\
65.5\end{array}$ & $\begin{array}{c}65.5 \\
\text { to } \\
66.0\end{array}$ & $\begin{array}{c}66.0 \\
\text { to } \\
66.5\end{array}$ & $\begin{array}{c}66.5 \\
\text { to } \\
67.0\end{array}$ & $\begin{array}{c}67.0 \\
\text { to } \\
67.5\end{array}$ \\
\hline & No. of cts. & 1 & & 3 & 4 & 14 & 26 & 43 & 27 & 26 & 25 & 13 & 7 & 6 & 3 & 1 \\
\hline \multirow[t]{2}{*}{ MgO } & Range, \% & $\begin{array}{l}0 \\
\text { to } \\
0.5 \\
\end{array}$ & $\begin{array}{l}0.5 \\
\text { to } \\
1.0 \\
\end{array}$ & $\begin{array}{l}1.0 \\
\text { to } \\
1.5\end{array}$ & $\begin{array}{l}1.5 \\
\text { to } \\
2.0\end{array}$ & $\begin{array}{l}2.0 \\
\text { to } \\
2.5\end{array}$ & $\begin{array}{l}2.5 \\
\text { to } \\
3.0\end{array}$ & $\begin{array}{l}3.0 \\
\text { to } \\
3.5\end{array}$ & $\begin{array}{l}3.5 \\
\text { to } \\
4.0\end{array}$ & $\begin{array}{l}4.0 \\
\text { to } \\
4.5\end{array}$ & $\begin{array}{l}4.5 \\
\text { to } \\
5.0\end{array}$ & & & & & \\
\hline & No. of cts. & 3 & 20 & 41 & 34 & 9 & 21 & 21 & 23 & 19 & 8 & & & & & \\
\hline \multirow[t]{2}{*}{$\mathrm{SO}_{3}$} & Range, \% & $\begin{array}{l}1.2 \\
\text { to } \\
1.4\end{array}$ & $\begin{array}{l}1.4 \\
\text { to } \\
1.6\end{array}$ & $\begin{array}{l}1.6 \\
\text { to } \\
1.8\end{array}$ & $\begin{array}{l}1.8 \\
\text { to } \\
2.0\end{array}$ & $\begin{array}{l}2.0 \\
\text { to } \\
2.2\end{array}$ & $\begin{array}{l}2.2 \\
\text { to } \\
2.4\end{array}$ & $\begin{array}{l}2.4 \\
\text { to } \\
2.6\end{array}$ & $\begin{array}{l}2.6 \\
\text { to } \\
2.8\end{array}$ & $\begin{array}{l}2.8 \\
\text { to } \\
3.0\end{array}$ & $\begin{array}{l}3.0 \\
\text { to } \\
3.2\end{array}$ & $\begin{array}{l}3.2 \\
\text { to } \\
\mathbf{3 . 4}\end{array}$ & $\begin{array}{l}3.4 \\
\text { to } \\
3.6\end{array}$ & & & \\
\hline & No. of cts. & 5 & 33 & 43 & 43 & 27 & 28 & 11 & 5 & 3 & & & 1 & & & \\
\hline \multirow[t]{2}{*}{$\begin{array}{l}\text { Loss on } \\
\text { ignition }\end{array}$} & Range, \% & $\begin{array}{l}0.3 \\
\text { to } \\
0.6\end{array}$ & $\begin{array}{l}0.6 \\
\text { to } \\
0.9\end{array}$ & $\begin{array}{l}0.9 \\
\text { to } \\
1.2\end{array}$ & $\begin{array}{l}1.2 \\
\text { to } \\
1.5\end{array}$ & $\begin{array}{l}1.5 \\
\text { to } \\
1.8\end{array}$ & $\begin{array}{l}1.8 \\
\text { to } \\
2.1\end{array}$ & $\begin{array}{l}2.1 \\
\text { to } \\
2.4\end{array}$ & $\begin{array}{l}2.4 \\
\text { to } \\
2.7\end{array}$ & $\begin{array}{l}2.7 \\
\text { to } \\
3.0\end{array}$ & $\begin{array}{l}3.0 \\
\text { to } \\
3.3\end{array}$ & $\begin{array}{l}3.3 \\
\text { to } \\
3.6\end{array}$ & & & & \\
\hline & No. of ets. & 2 & 49 & 58 & 26 & 33 & 12 & 11 & 3 & 3 & 1 & 1 & & & & \\
\hline \multirow[t]{2}{*}{$\begin{array}{l}\text { Insoluble } \\
\text { residue }\end{array}$} & Range, $\%$ & $\begin{array}{l}0 \\
\text { to } \\
0.1\end{array}$ & $\begin{array}{l}0.1 \\
\text { to } \\
0.2\end{array}$ & $\begin{array}{l}0.2 \\
\text { to } \\
0.3\end{array}$ & $\begin{array}{l}0.3 \\
\text { to } \\
0.4\end{array}$ & $\begin{array}{l}0.4 \\
\text { to } \\
0.5\end{array}$ & $\begin{array}{l}0.5 \\
\text { to } \\
0.6\end{array}$ & $\begin{array}{l}0.6 \\
\text { to } \\
0.7\end{array}$ & $\begin{array}{l}0.7 \\
\text { to } \\
0.8\end{array}$ & $\begin{array}{l}0.8 \\
\text { to } \\
0.9\end{array}$ & $\begin{array}{l}0.9 \\
\text { to } \\
1.0\end{array}$ & $\begin{array}{l}1.0 \\
\text { to } \\
1.1\end{array}$ & & & & \\
\hline & No. of cts. & 19 & 60 & 64 & 30 & 17 & 3 & 2 & 1 & 2 & & 1 & & & & \\
\hline
\end{tabular}


TABLE 2-1. Frequency distribution of cements with respect to chemical composition and fineness-Continued

\begin{tabular}{|c|c|c|c|c|c|c|c|c|c|c|c|c|c|c|c|}
\hline \multirow[t]{2}{*}{$\mathrm{C}_{3} \mathrm{~A}$} & Range, $\%$ & $\begin{array}{r}1 \\
\text { to } \\
2\end{array}$ & $\begin{array}{r}2 \\
\text { to } \\
3 \\
\end{array}$ & $\begin{array}{r}3 \\
\text { to } \\
4 \\
\end{array}$ & $\begin{array}{r}4 \\
\text { to } \\
5 \\
\end{array}$ & $\begin{array}{r}5 \\
\text { to } \\
6\end{array}$ & $\begin{array}{r}6 \\
\text { to } \\
7 \\
\end{array}$ & $\begin{array}{r}7 \\
\text { to } \\
8 \\
\end{array}$ & $\begin{array}{r}8 \\
\text { to } \\
9 \\
\end{array}$ & $\begin{array}{r}9 \\
\text { to } \\
10\end{array}$ & $\begin{array}{l}10 \\
\text { to } \\
11\end{array}$ & $\begin{array}{l}11 \\
\text { to } \\
12\end{array}$ & $\begin{array}{l}12 \\
\text { to } \\
13\end{array}$ & $\begin{array}{l}13 \\
\text { to } \\
14\end{array}$ & $\begin{array}{l}14 \\
\text { to } \\
15\end{array}$ \\
\hline & No. of ets. & 2 & 1 & 8 & 5 & 16 & 32 & 22 & 17 & 16 & 12 & 25 & 16 & 16 & 8 \\
\hline \multirow[t]{2}{*}{$\mathrm{C}_{3} \mathrm{~S}$} & Range, $\%$ & $\begin{array}{l}20 \\
\text { to } \\
25\end{array}$ & $\begin{array}{l}25 \\
\text { to } \\
30\end{array}$ & $\begin{array}{l}30 \\
\text { to } \\
35\end{array}$ & $\begin{array}{l}35 \\
\text { to } \\
40\end{array}$ & $\begin{array}{l}40 \\
\text { to } \\
45\end{array}$ & $\begin{array}{l}45 \\
\text { to } \\
50\end{array}$ & $\begin{array}{l}50 \\
\text { to } \\
55\end{array}$ & $\begin{array}{l}55 \\
\text { to } \\
60\end{array}$ & $\begin{array}{l}60 \\
\text { to } \\
65\end{array}$ & $\begin{array}{l}65 \\
\text { to } \\
70\end{array}$ & & & & \\
\hline & No. of cts. & 1 & & 1 & 5 & 33 & 69 & 48 & 29 & 7 & 6 & & & & \\
\hline \multirow[t]{2}{*}{$\mathrm{C}_{2} \mathrm{~S}$} & Range, $\%$ & $\begin{array}{r}5 \\
\text { to } \\
10 \\
\end{array}$ & $\begin{array}{l}10 \\
\text { to } \\
15\end{array}$ & $\begin{array}{l}15 \\
\text { to } \\
20 \\
\end{array}$ & $\begin{array}{l}20 \\
\text { to } \\
25 \\
\end{array}$ & $\begin{array}{l}25 \\
\text { to } \\
30 \\
\end{array}$ & $\begin{array}{l}30 \\
\text { to } \\
35 \\
\end{array}$ & $\begin{array}{l}35 \\
\text { to } \\
40\end{array}$ & $\begin{array}{l}40 \\
\text { to } \\
45\end{array}$ & $\begin{array}{l}45 \\
\text { to } \\
50\end{array}$ & & & & & \\
\hline & No. of cts. & 3 & 14 & 27 & 43 & 58 & 37 & 11 & 4 & 2 & & & & & \\
\hline \multirow[t]{2}{*}{$\mathrm{C}_{4} \mathrm{AF}$} & Range, $\%$ & $\begin{array}{r}1 \\
\text { to } \\
2\end{array}$ & $\begin{array}{r}4 \\
\text { to } \\
5 \\
\end{array}$ & $\begin{array}{r}5 \\
\text { to } \\
6 \\
\end{array}$ & $\begin{array}{r}6 \\
\text { to } \\
7 \\
\end{array}$ & $\begin{array}{r}7 \\
\text { to } \\
8 \\
\end{array}$ & $\begin{array}{r}8 \\
\text { to } \\
9\end{array}$ & $\begin{array}{r}9 \\
\text { to } \\
10\end{array}$ & $\begin{array}{l}10 \\
\text { to } \\
11\end{array}$ & $\begin{array}{l}11 \\
\text { to } \\
12\end{array}$ & $\begin{array}{l}12 \\
\text { to } \\
13\end{array}$ & $\begin{array}{l}13 \\
\text { to } \\
14\end{array}$ & $\begin{array}{l}14 \\
\text { to } \\
15\end{array}$ & $\begin{array}{l}15 \\
\text { to } \\
16\end{array}$ & $\begin{array}{l}16 \\
\text { to } \\
17\end{array}$ \\
\hline & No. of ets & 3 & 1 & 3 & 9 & 20 & 32 & 39 & 29 & 30 & 11 & 8 & 7 & 6 & 1 \\
\hline \multirow{3}{*}{$\begin{array}{l}\mathrm{A} / \mathrm{F} \\
\mathrm{S} /(\mathrm{A}+\mathrm{F})\end{array}$} & Range, ratio & $\begin{array}{r}0.6 \\
\text { to } \\
0.9\end{array}$ & $\begin{array}{r}0.9 \\
\text { to } \\
1.2\end{array}$ & $\begin{array}{r}1.2 \\
\text { to } \\
1.5\end{array}$ & $\begin{array}{r}1.5 \\
\text { to } \\
1.8\end{array}$ & $\begin{array}{r}1.8 \\
\text { to } \\
2.1\end{array}$ & $\begin{array}{r}2.1 \\
\text { to } \\
2.4\end{array}$ & $\begin{array}{r}2.4 \\
\text { to } \\
2.7\end{array}$ & $\begin{array}{r}2.7 \\
\text { to } \\
3.0\end{array}$ & $\begin{array}{r}3.0 \\
\text { to } \\
3.3\end{array}$ & $\begin{array}{r}3.3 \\
\text { to } \\
3.6\end{array}$ & $\begin{array}{l}3.6 \\
\text { to } \\
3.9\end{array}$ & $\begin{array}{l}3.9 \\
\text { to } \\
4.2\end{array}$ & $\begin{array}{l}4.2 \\
\text { to } \\
4.5\end{array}$ & $\begin{array}{l}4.5 \\
\text { to } \\
4 .\end{array}$ \\
\hline & No. of cts. ${ }^{*}$ & 4 & 33 & 46 & 31 & 25 & 20 & 22 & 10 & 3 & 1 & 1 & & & \\
\hline & No. of cts.* & & & & 1 & 16 & 43 & 58 & 39 & 15 & 10 & 8 & 5 & & 1 \\
\hline \multirow[t]{2}{*}{$\mathrm{C} / \mathrm{S}^{* *}$} & Range, ratio & $\begin{array}{r}2.4 \\
\text { to } \\
2.5 \\
\end{array}$ & $\begin{array}{r}2.5 \\
\text { to } \\
2.6 \\
\end{array}$ & $\begin{array}{r}2.6 \\
\text { to } \\
2.7 \\
\end{array}$ & $\begin{array}{r}2.7 \\
\text { to } \\
2.8\end{array}$ & $\begin{array}{r}2.8 \\
\text { to } \\
2.9 \\
\end{array}$ & $\begin{array}{r}2.9 \\
\text { to } \\
3.0 \\
\end{array}$ & $\begin{array}{l}3.0 \\
\text { to } \\
3.1 \\
\end{array}$ & $\begin{array}{l}3.1 \\
\text { to } \\
3.2 \\
\end{array}$ & $\begin{array}{l}3.2 \\
\text { to } \\
3.3 \\
\end{array}$ & & & & & \\
\hline & No. of cts. & 3 & 3 & 17 & 37 & 46 & 45 & 32 & 13 & 3 & & & & & \\
\hline \multirow[t]{2}{*}{$\mathrm{C} /(\mathrm{S}+\mathrm{A}+\mathrm{F})^{* * *}$} & Range, ratio & $\begin{array}{c}0.80 \\
\text { to } \\
0.82\end{array}$ & $\begin{array}{c}0.82 \\
\text { to } \\
0.84\end{array}$ & $\begin{array}{c}0.84 \\
\text { to } \\
0.86\end{array}$ & $\begin{array}{c}0.86 \\
\text { to } \\
0.88\end{array}$ & $\begin{array}{c}0.88 \\
\text { to } \\
0.90\end{array}$ & $\begin{array}{c}0.90 \\
\text { to } \\
0.92\end{array}$ & $\begin{array}{c}0.92 \\
\text { to } \\
0.94\end{array}$ & $\begin{array}{c}0.94 \\
\text { to } \\
0.96\end{array}$ & $\begin{array}{c}0.96 \\
\text { to } \\
0.98\end{array}$ & $\begin{array}{c}0.98 \\
\text { to } \\
1.00\end{array}$ & & & & \\
\hline & No. of cts. & 2 & 3 & 11 & 31 & 44 & 41 & 32 & 20 & 14 & 1 & & & & \\
\hline \multirow[t]{2}{*}{$\begin{array}{l}\text { Fineness AP } \\
\text { Method }\end{array}$} & Range, $\mathrm{cm}^{2} / \mathrm{g}$ & $\begin{array}{c}2500 \\
\text { to } \\
3000\end{array}$ & $\begin{array}{c}3000 \\
\text { to } \\
3500\end{array}$ & $\begin{array}{c}3500 \\
\text { to } \\
4000\end{array}$ & $\begin{array}{c}4000 \\
\text { to } \\
4500\end{array}$ & $\begin{array}{c}4500 \\
\text { to } \\
5000\end{array}$ & $\begin{array}{c}5000 \\
\text { to } \\
5500\end{array}$ & $\begin{array}{c}5500 \\
\text { to } \\
6000\end{array}$ & & & & & & & \\
\hline & No. of ets. & 9 & 126 & 40 & 7 & 13 & 3 & 2 & & & & & & & \\
\hline \multirow[t]{2}{*}{$\begin{array}{l}\text { Fineness Wagner } \\
\text { Turbidimeter }\end{array}$} & Range $\mathrm{cm}^{2} / \mathrm{g}$ & $\begin{array}{c}1200 \\
\text { to } \\
1400\end{array}$ & $\begin{array}{c}1400 \\
\text { to } \\
1600\end{array}$ & $\begin{array}{c}1600 \\
\text { to } \\
1800\end{array}$ & $\begin{array}{c}1800 \\
\text { to } \\
2000\end{array}$ & $\begin{array}{c}2000 \\
\text { to } \\
2200\end{array}$ & $\begin{array}{c}2200 \\
\text { to } \\
2400\end{array}$ & $\begin{array}{c}2400 \\
\text { to } \\
2600\end{array}$ & $\begin{array}{c}2600 \\
\text { to } \\
2800\end{array}$ & $\begin{array}{c}2800 \\
\text { to } \\
3000\end{array}$ & & & & & \\
\hline & No. of ets. & 1 & 15 & 64 & 64 & 16 & 11 & 6 & 1 & 1 & & & & & \\
\hline
\end{tabular}

*Does not include 3 white portland cements.

$* * \mathrm{CaO}$ corrected for amount combined with $\mathrm{SO}_{3}$.

*** $\mathrm{CaO} /\left(2.8 \mathrm{SiO}_{2}+1.18 \mathrm{Al}_{2} \mathrm{O}_{3}+0.65 \mathrm{Fe}_{2} \mathrm{O}_{3}\right), \mathrm{CaO}$ corrected for amount combined with $\mathrm{SO}_{3}$ but not corrected for free lime.

TABLE 2-2. Frequency distribution of cements with respect to water used for normal consistency of neat cements

\begin{tabular}{|c|c|c|c|c|c|c|c|c|c|c|c|c|}
\hline \multirow{3}{*}{ Type cement } & \multicolumn{11}{|c|}{ Percentage water used for normal consistency } & \multirow{3}{*}{ Total } \\
\hline & $\begin{array}{l}21 \\
\text { to } \\
22\end{array}$ & $\begin{array}{l}22 \\
\text { to } \\
23\end{array}$ & $\begin{array}{l}23 \\
\text { to } \\
24\end{array}$ & $\begin{array}{l}24 \\
\text { to } \\
25\end{array}$ & $\begin{array}{l}25 \\
\text { to } \\
26\end{array}$ & $\begin{array}{l}26 \\
\text { to } \\
27\end{array}$ & $\begin{array}{l}27 \\
\text { to } \\
28\end{array}$ & $\begin{array}{l}28 \\
\text { to } \\
29\end{array}$ & $\begin{array}{l}29 \\
\text { to } \\
30\end{array}$ & $\begin{array}{l}30 \\
\text { to } \\
31\end{array}$ & $\begin{array}{l}31 \\
\text { to } \\
32\end{array}$ & \\
\hline & \multicolumn{11}{|c|}{ Number of cements } & \\
\hline $\mathrm{IA}$ & - & 1 & 15 & 30 & 26 & 10 & & & & & & 82 \\
\hline IA & 1 & 6 & $\begin{array}{r}1 \\
22\end{array}$ & 21 & $\begin{array}{r}2 \\
14\end{array}$ & 3 & 1 & 1 & 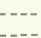 & 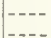 & 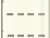 & $\begin{array}{r}8 \\
68\end{array}$ \\
\hline IIA-" & & & & & 2 & & -- & 1 & & $-\cdots$ & 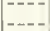 & 3 \\
\hline & $\cdots$ & --- & 1 & 1 & 1 & 4 & 2 & 9 & 1 & ... & 1 & 20 \\
\hline IV and $\mathrm{V}_{-.}$ & 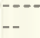 & 2 & 6 & 3 & 3 & 1 & 1 & 1 & 1 & $\mid--\cdot$ & - n lo & 15 \\
\hline Total... & 1 & 9 & 45 & 59 & 48 & 18 & 4 & 12 & 2 & $\ldots$ & 1 & 199 \\
\hline
\end{tabular}

variables and the water requirements of the $1: 2.75$ mortars. Plots of air-content values of another series of cements, studied in a previous investigation [5] indicated that there was a relationship between the air contents of the two types of mortars.

In table 2-6 are presented equations indicating the effect of different independent variables on the percentage water used for standard consistency of the 1:2.75 mortars. Equations (1) through (6) were obtained on the AE + NAE cements and eqs (7) through (12) on the NAE cements. Equation 1 was computed from commonly determined variables, whereas in eq (2), other variables indicated by the high-low test as being significant were included, giving a significantly reduced S.D. value (table 2-22). Use of $\mathrm{Al}_{2} \mathrm{O}_{3}$ alone resulted in lower S.D. values than when the related variables, $\mathrm{A} / \mathrm{F}$ or $\mathrm{C}_{3} \mathrm{~A}$, were used, as may be noted by comparing eqs (1) with (3) and (5), or (2) with (4) and (6). In each instance, the addition of minor or trace elements resulted in slightly lower S.D. values than when they were not used (table 2-22).

Using the high-low comparison test previously described it was noted that with the deviations from eq (2), the " $t$ " for the difference between means of the "high 20 " and "low 20 " was in the 5 percent range for air-permeability fineness and in the 20 percent range for $\mathrm{Zn}$. When used with the other independent variables of eq (2) the $\mathrm{Zn}$ had a coefficient which was not significant, and the coefficient for the fineness was -0.00030 with an 


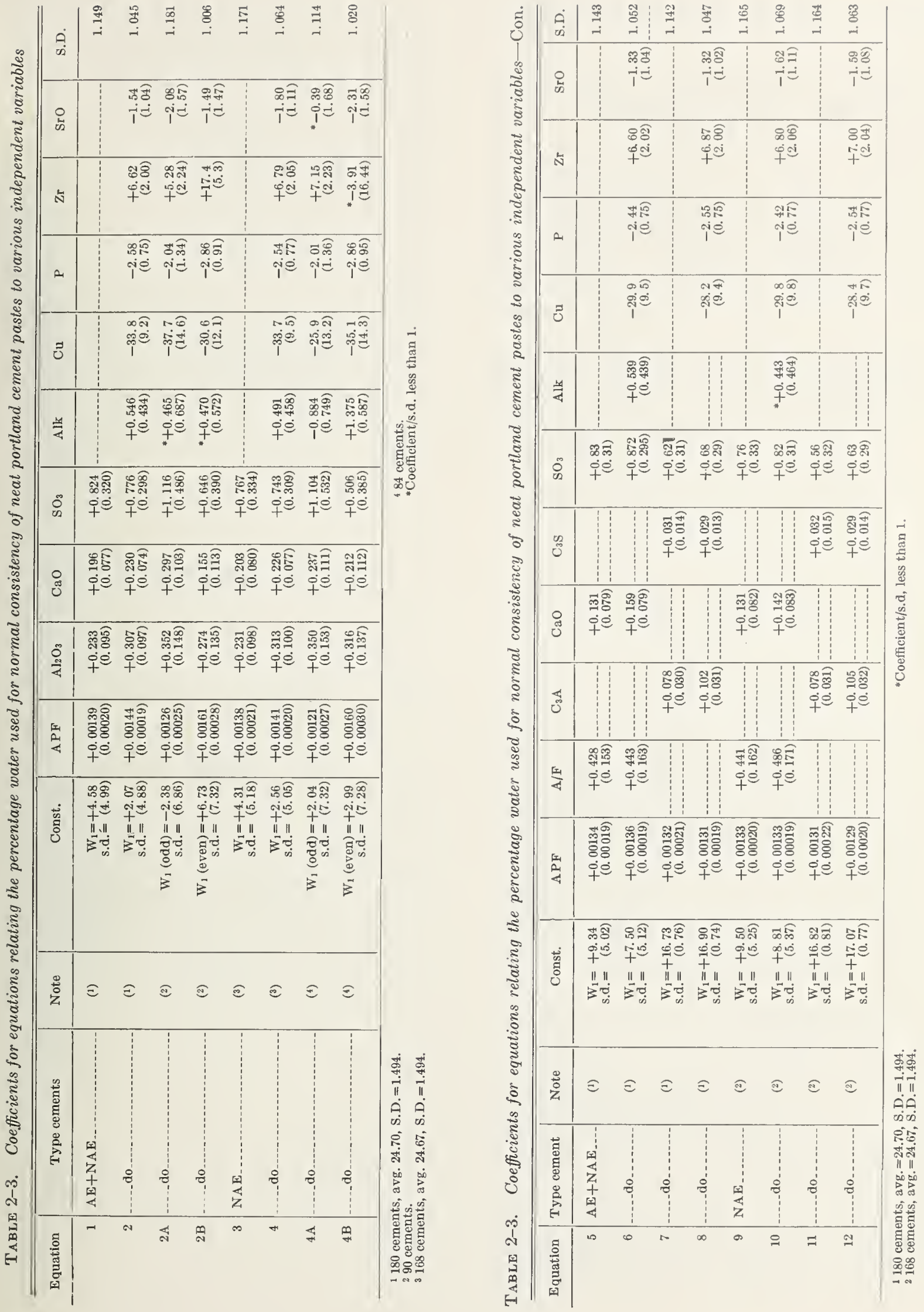


TABLE 2-4. Calculated contribution of independent variables to the amount of water used for neat cement pastes of normal consistency

\begin{tabular}{|c|c|c|c|c|c|}
\hline $\begin{array}{l}\text { Inde- } \\
\text { pendent } \\
\text { variable }\end{array}$ & $\begin{array}{l}\text { Values used for } \\
\text { independent } \\
\text { variable }\end{array}$ & $\begin{array}{l}\text { Range of } \\
\text { inde- } \\
\text { pendent } \\
\text { variable }\end{array}$ & $\begin{array}{l}\text { Coeffi- } \\
\text { cients } \\
\text { from } \\
\text { eq (2) } \\
\text { table } 2-3\end{array}$ & $\begin{array}{c}\text { Calculated } \\
\text { contribution } \\
\text { to } W_{1}\end{array}$ & $\begin{array}{l}\text { Calcu- } \\
\text { lated } \\
\text { range } \\
\text { of cont. } \\
\text { to } W_{1}\end{array}$ \\
\hline $\mathrm{APF}$ & $\begin{array}{c}3000 \text { to } 5500 \\
\mathrm{~cm}^{2} / \mathrm{g} \text {. }\end{array}$ & 2500 & 0.00144 & $\begin{array}{r}\text { Const. }=2.1 \\
+4.3 \text { to }+7.9\end{array}$ & 3.6 \\
\hline $\begin{array}{l}\mathrm{Al}_{2} \mathrm{O}_{3} \\
\mathrm{CaO}_{-} \\
\mathrm{SO}_{3} \\
\mathrm{Alk}_{\ldots} \\
\mathrm{Cu} . \\
\mathrm{P} \\
\mathrm{Zr}_{-} \\
\mathrm{SrO}^{-}\end{array}$ & $\begin{array}{r}3.0 \text { to } .5 \% \\
61 \text { to } 67 \% \\
1.4 \text { to } 3.0 \% \\
0 \text { to } 1.2 \% \\
0 \text { to } 0.05 \% \\
0 \text { to } 0.5 \% \\
0 \text { to } 0.5 \% \\
0 \text { to } 0.35 \%\end{array}$ & $\begin{array}{l}4.5 \\
6 \\
1.6 \\
1.2 \\
0.05 \\
0.5 \\
0.5 \\
0.35\end{array}$ & $\begin{array}{r}0.307 \\
0.230 \\
0.776 \\
0.546 \\
-33.8 \\
-2.58 \\
6.62 \\
-1.54\end{array}$ & $\begin{array}{r}+0.9 \text { to }+2.3 \\
+14.0 \text { to }+15.4 \\
+1.1 \text { to }+2.3 \\
0 \text { to }+0.7 \\
0 \text { to }-1.7 \\
0 \text { to }-1.3 \\
0 \text { to }+3.3 \\
0 \text { to }-0.5\end{array}$ & $\begin{array}{l}1.4 \\
1.4 \\
1.2 \\
0.7 \\
1.7 \\
1.3 \\
3.3 \\
0.5\end{array}$ \\
\hline
\end{tabular}

TABLE 2-5. Frequency distribution of cements with respect to water used for standard consistency, 1:2.75 cement to graded Ottawa sand mortar

\begin{tabular}{|c|c|c|c|c|c|c|c|c|c|c|c|c|c|}
\hline \multirow{3}{*}{$\begin{array}{l}\text { Type } \\
\text { cement }\end{array}$} & \multicolumn{12}{|c|}{ Percentage water used for standard consistency } & \multirow{3}{*}{ Total } \\
\hline & $\begin{array}{l}44 \\
\text { to } \\
45\end{array}$ & $\begin{array}{l}45 \\
\text { to } \\
46\end{array}$ & \begin{tabular}{|l|}
46 \\
to \\
47
\end{tabular} & $\begin{array}{l}47 \\
\text { to } \\
48\end{array}$ & $\begin{array}{c}48 \\
\text { to } \\
49\end{array}$ & $\begin{array}{l}49 \\
\text { to } \\
50\end{array}$ & $\begin{array}{l}50 \\
\text { to } \\
51\end{array}$ & $\begin{array}{l}51 \\
\text { to } \\
52\end{array}$ & $\begin{array}{l}52 \\
\text { to } \\
53\end{array}$ & $\begin{array}{l}53 \\
\text { to } \\
54\end{array}$ & $\begin{array}{l}54 \\
\text { to } \\
55\end{array}$ & $\begin{array}{l}55 \\
\text { to } \\
56\end{array}$ & \\
\hline & \multicolumn{12}{|c|}{ Number of cements } & \\
\hline & & & & 18 & 38 & 13 & 9 & 1 & 1 & 1 & . & 1 & 82 \\
\hline IA & 1 & $\begin{array}{l}1 \\
1\end{array}$ & $\begin{array}{r}4 \\
13\end{array}$ & 19 & $\begin{array}{r}2 \\
15\end{array}$ & 11 & 9 & 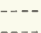 & 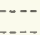 & - & $\cdots$ & 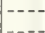 & $\begin{array}{r}8 \\
68\end{array}$ \\
\hline & $\cdots$ & 2 & & 1 & & & & & $\cdots$ & - n- & $\cdots$ & 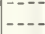 & 3 \\
\hline 111. & & 1 & 1 & 7 & 5 & 4 & 1 & 1 & -... & 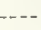 & $-\ldots$ & - & 20 \\
\hline lil and $\mathrm{V}$ & 1 & 2 & 2 & 3 & 4 & 1 & 3 & 2 & .... & $-\cdots$ & $-\infty$ & $-\cdots$ & $\begin{array}{r}3 \\
15\end{array}$ \\
\hline Total & 2 & 7 & 20 & 48 & 64 & 29 & 22 & 4 & 1 & 1 & $\ldots$ & 1 & 199 \\
\hline
\end{tabular}

s.d. value of 0.00020 . The S.D. value was 1.143 when using the fineness values with the $\mathrm{AE}+\mathrm{NAE}$ cements. When these two variables were used with the NAE cements, neither was significant.

With the NAE cements (table 2-6) the three eqs (7), (9), and (11) use the same commonly determined variables as are used in corresponding eqs (1), (3), and (5) of table 2-6. Here again the lowest S.D. of the three was obtained with $\mathrm{Al}_{2} \mathrm{O}$ as one of the independent variables (eq (7)), although the S.D. values with the $A / F$ ratio and $\mathrm{C}_{3} \mathrm{~A}$ are only slightly higher. Including the minor constituents and trace elements in eqs (8), (10), and (12) resulted in lower S.D. values than in the corresponding eqs (7), (9), and (11) where they were not included.

In the previously mentioned interlaboratory tests, using a different series of cements, the standard deviation value of 1.17 was obtained for the percentage water used for standard consistency of the $1: 2.75$ mortars made of 44 cements. The S.D. values presented in table 2-6 compare reasonably well with this value.

Using approximate ranges of values of independent variables from those presented in table $2-1$ and the coefficients of eq (2) of table $2-6$, the calculated contributions to the amount of water used for standard consistency of the $1: 2.75$ cement

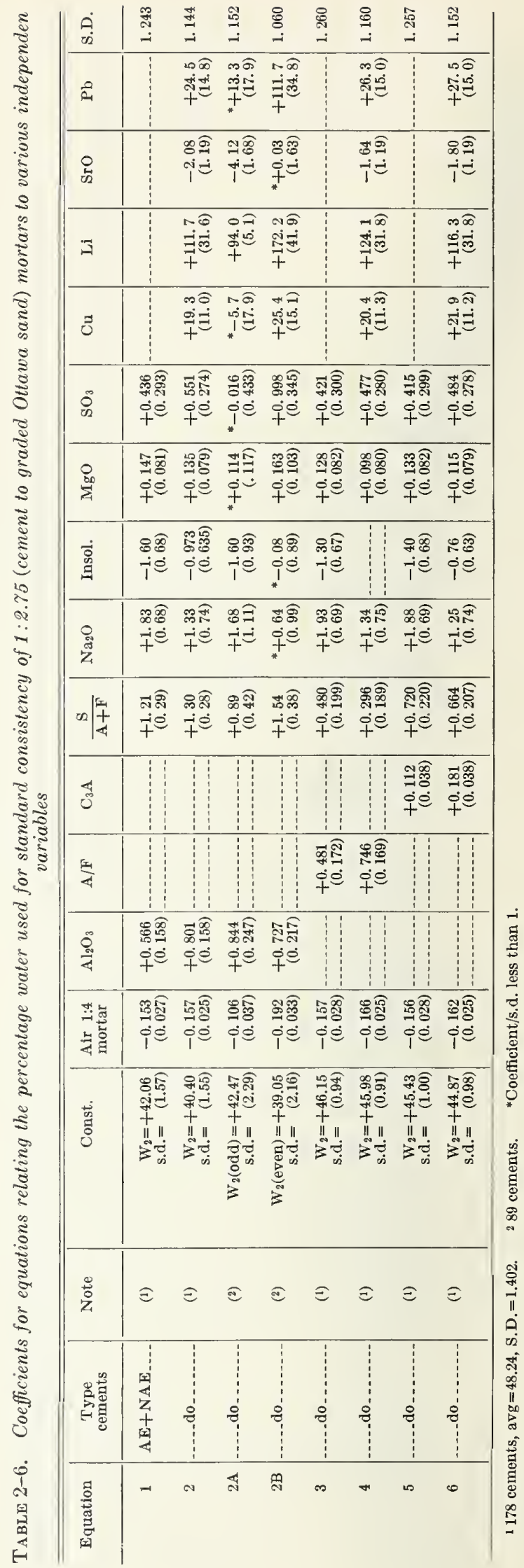


to graded Ottawa sand mortars, $W_{2}$, are presented in table 2-7. Also presented in this table are the ranges of the computed values.

\subsection{Water Requirements for 1:4 Cement to Standard Ottawa Sand Mortars}

The frequeney distribution of the eements with respeet to air content of 1:4 mortars of standard eonsisteney is presented in table $2-8$, and the frequency distribution with respeet to the amount of water used for these mortars is presented in table 2-9. The differenee in water requirements of the air-entraining and the non-air-entraining eements is more pronouneed in table 2-9 than in tables 2-2 and 2-5.

The average amount of water used was 70.40 percent when both the $\mathrm{AE}$ and NAE eements were eonsidered, 71.31 pereent when eomputed for the NAE cements ${ }^{5}$ and 57.66 for the $12 \mathrm{AE}$ cements. The standard deviation of the $\mathrm{AE}+$ NAE eements was 3.989 and for the NAE cements it was 2.091 .

TABLE 2-7. Calculaled contribution of independent variables to the amount of water used for 1:2.75 mortars of standard consistency and the calculated ranges of such contributions

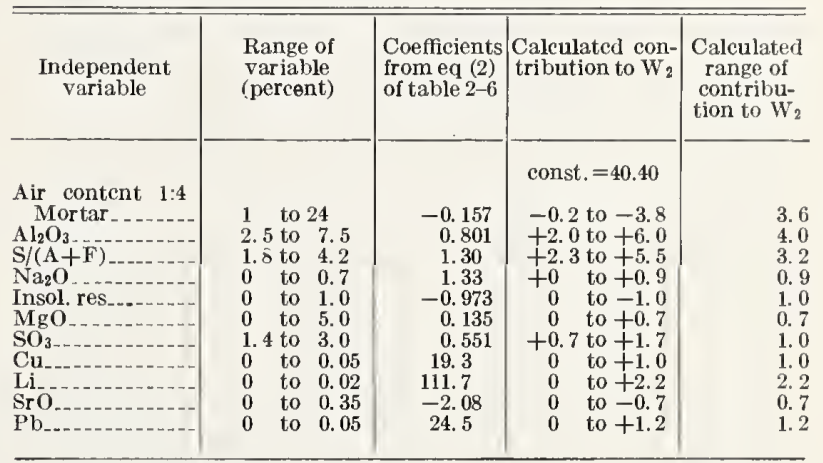

TABLE 2-8. Frequency distribution of the cements with respect to air content in 1:4 mortars of standard consistency

\begin{tabular}{|c|c|c|c|c|c|c|c|c|c|c|c|}
\hline \multirow{3}{*}{ Type cement } & \multicolumn{10}{|c|}{$\begin{array}{l}\text { Percentage air content of 1:4 (cement to } \\
\text { standard Ottawa sand) mortar }\end{array}$} & \multirow{3}{*}{ Total } \\
\hline & $\begin{array}{c}1 \\
\text { to } \\
4\end{array}$ & $\begin{array}{c}4 \\
\text { to } \\
7\end{array}$ & $\begin{array}{l}7 \\
\text { to } \\
10\end{array}$ & \begin{tabular}{|l}
10 \\
to \\
13
\end{tabular} & $\begin{array}{l}13 \\
\text { to } \\
16\end{array}$ & $\begin{array}{l}16 \\
\text { to } \\
19\end{array}$ & $\begin{array}{l}19 \\
\text { to } \\
21\end{array}$ & $\begin{array}{l}21 \\
\text { to } \\
24\end{array}$ & $\begin{array}{l}24 \\
\text { to } \\
27\end{array}$ & $\begin{array}{l}27 \\
\text { to } \\
30\end{array}$ & \\
\hline & \multicolumn{10}{|c|}{ Number of cements } & \\
\hline 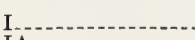 & & 37 & 41 & 3 & 1 & & & & & & \\
\hline $\begin{array}{l}\text { IA } \\
\text { II }\end{array}$ & -1 & - & 95 & 5 & -- & 2 & 5 & --- & 1 & $\cdots$ & 8 \\
\hline IIA & 1 & 30 & 20 & 5 & $\begin{array}{l}1 \\
1\end{array}$ & -1 & $-\cdots$ & 1 & - & -- & \\
\hline & $-\cdots$ & 11 & 7 & 2 & & & $-\cdots$ & $\ldots$ & - & $\ldots$ & 20 \\
\hline IIIA & 1 & & 4 & 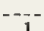 & 1 & 2 & $-\cdots$ & $\cdots-$ & $-\cdots$ & $\cdots$ & 3 \\
\hline and $v_{-}$ & 1 & 9 & 4 & 1 & & $-\cdots$ & $\cdots$ & --- & ---- & & \\
\hline Total & 2 & 93 & 77 & 11 & 4 & 5 & 5 & 1 & 1 & -.. & 199 \\
\hline
\end{tabular}

${ }_{5}$ The overall average was affected so slightly by the $\mathrm{AE}$ cements (which had an average of less than 60 percent) bccause there were so few of them. 
TABLE 2-9. Frequency distribution of the cements with respect to water used for standard consistency of $1: 4$ cement to standard Ottawa sand mortars

\begin{tabular}{|c|c|c|c|c|c|c|c|c|c|c|c|c|c|}
\hline \multirow{3}{*}{$\begin{array}{c}\text { Type } \\
\text { cement }\end{array}$} & \multicolumn{12}{|c|}{ Percentage water used for standard consistency } & \multirow{3}{*}{ Total } \\
\hline & \begin{tabular}{|l}
54 \\
to \\
56
\end{tabular} & $\begin{array}{l}56 \\
\text { to } \\
58\end{array}$ & $\begin{array}{l}58 \\
\text { to } \\
60\end{array}$ & $\begin{array}{l}60 \\
\text { to } \\
62\end{array}$ & $\begin{array}{l}62 \\
\text { to } \\
64\end{array}$ & \begin{tabular}{|l}
64 \\
to \\
66
\end{tabular} & $\begin{array}{l}66 \\
\text { to } \\
68\end{array}$ & $\begin{array}{l}68 \\
\text { to } \\
70\end{array}$ & \begin{tabular}{|l}
70 \\
to \\
72
\end{tabular} & \begin{tabular}{|l}
72 \\
to \\
74
\end{tabular} & \begin{tabular}{|l|}
74 \\
to \\
76
\end{tabular} & \begin{tabular}{|l|}
76 \\
to \\
78
\end{tabular} & \\
\hline & \multicolumn{12}{|c|}{ Number of cements } & \\
\hline & & & & & - & . & 1 & $\cdots$ & 43 & 26 & 7 & 5 & 82 \\
\hline & 1 & 4 & $\ldots$ & 3 & & & -2 & 4 & 35 & 18 & 8 & 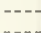 & $\begin{array}{r}8 \\
67 \\
67\end{array}$ \\
\hline IIA & 1 & -- & - & 1 & 1 & & & & & & & & 3 \\
\hline & 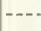 & - & $\cdots$ & 1 & $\ldots$ & 1 & 3 &.-- & 10 & 2 & 3 & $-\cdots$ & 20 \\
\hline IV and $V_{-}$ & $-\cdots$ & 1 & 1 & -- & 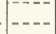 & 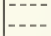 & 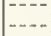 & 1 & 2 & 10 & 1 & $-\cdots$ & 14 \\
\hline Total & 2 & 5 & 1 & 6 & 1 & 1 & 6 & 5 & 90 & 56 & 19 & 5 & 197 \\
\hline
\end{tabular}

The equations indicating the relationship of the various independent variables with the water used for the 1:4 mortars of standard consistency of these cements are presented in table 2-10. Equations (1) through (7) were obtained for the $\mathrm{AE}$ plus the NAE cements and eqs. (8) through (14) for the NAE cements.

Considering the $\mathrm{AE}+\mathrm{NAE}$ cements, the relationship of the amount of water used to the percentage air entrained is presented in eq (1) of table $2-10$. The S.D. value of 1.984 is considerably smaller than that of 3.989 (presented in Note 1 of this table) which was computed from the observed values of the water requirements of the different cements.

By including seven other commonly determined variables in the computations as in eq (2), a significantly lower S.D. value was attained (table 2-22) as was also the case in eqs (4) and (6) where the $A / F$ ratio and the $C_{3} A$, respectively, were used instead of the $\mathrm{Al}_{2} \mathrm{O}_{3}$.

By use of certain of the trace elements indicated by the high-low comparison as being significant, further reductions of the S.D. values were obtained as may be noted by comparing eq (2) with (3), (4) with (5), or (6) with (7).

Consideration of only the NAE cements resulted in the eqs (8) through (14) of table 2-10. With these cements, inclusion of the air content of the 1:4 mortars also reduced the S.D. value as indicated in eq (8), and inclusion of other commonly determined variables reduced the S.D. value still further as indicated in eqs (9), (11), and (13). (See also table 2-22.) Using the $\mathrm{A} / \mathrm{F}$ ratio (eq (11)) did not reduce the S.D. value as much as the use of $\mathrm{C}_{3} \mathrm{~A}$ or $\mathrm{Al}_{2} \mathrm{O}_{3}$ values (eqs (9) and (13)), respectively. By use of certain trace elements in the computations the S.D. values were reduced further as may be noted by comparing eqs (9) with (10), (11) with (12), and (13) with (14) (also table 2-22).

Comparing eqs (1) through (7) with eqs (8) through (14) (table 2-10) it may be noted that coefficients for the air content are greater in magnitude for the $\mathrm{AE}+\mathrm{NAE}$ cements than for the NAE cements alone. Also, $\mathrm{Na}_{2} \mathrm{O}$ and $\mathrm{Zr}$ are

\begin{tabular}{|c|c|c|c|c|c|c|c|c|c|}
\hline$\dot{\rho}$ & $\begin{array}{l}\overrightarrow{\mathrm{g}} \\
\stackrel{\mathrm{\sigma}}{-}\end{array}$ & 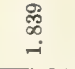 & 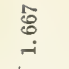 & 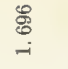 & 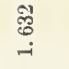 & $\stackrel{\leftrightarrow}{\infty}$ & 㣽 & - & $\widehat{0}$ \\
\hline 岕 & & & 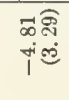 & 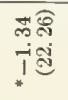 & 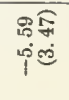 & & 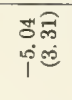 & & बे \\
\hline జि & & & 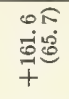 & 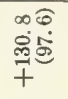 & 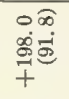 & & 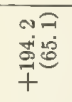 & & 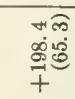 \\
\hline$>$ & & & $\begin{array}{l}\infty \hat{0} \\
\infty \\
+\infty \\
+\end{array}$ & 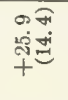 & $\begin{array}{l}0.6 \\
0.0 \\
7 \\
7\end{array}$ & & $\begin{array}{l}\text { Nकิ } \\
\text { बंट } \\
+\end{array}$ & & 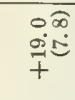 \\
\hline 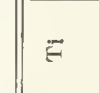 & & & 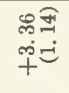 & 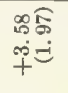 & 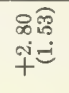 & & 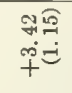 & & 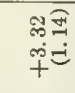 \\
\hline$\tilde{0}$ & & & 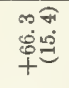 & 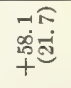 & 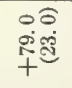 & & 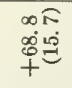 & & 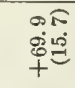 \\
\hline 总 & & $\begin{array}{l}\text { 중 } \\
i=\end{array}$ & స尺 & 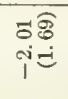 & $\begin{array}{l}\Re \widehat{Q} \\
i=\end{array}$ & $\begin{array}{l}\text { ঞक्ष } \\
i= \\
i=\end{array}$ & 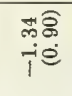 & & 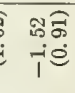 \\
\hline$\frac{1}{2 \pi}$ & & 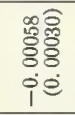 & 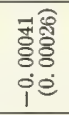 & 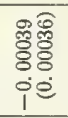 & 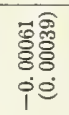 & 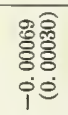 & 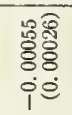 & 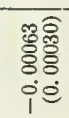 & 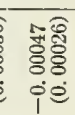 \\
\hline 另 & & 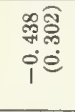 & & & & 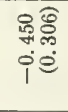 & & $\begin{array}{l}\text { s. } \\
\text { is } \\
\text { ie }\end{array}$ & \\
\hline 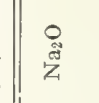 & & 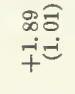 & 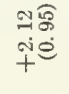 & 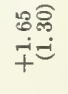 & 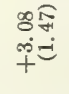 & 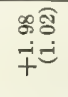 & 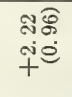 & $\begin{array}{l}+\vec{\delta} \\
+\overrightarrow{+}\end{array}$ & 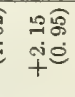 \\
\hline 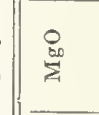 & & 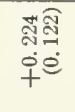 & 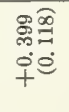 & 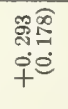 & 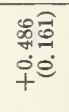 & 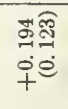 & 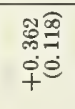 & 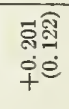 & $\begin{array}{l}0 \widehat{0} \\
0 \\
0 \\
+\stackrel{0}{\circ}\end{array}$ \\
\hline$\left.\approx\right|_{4} ^{\infty}$ & & 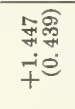 & $\begin{array}{l}\text { 고용 } \\
7 \text { †ं }\end{array}$ & 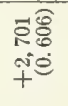 & 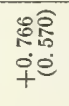 & 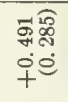 & 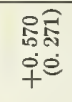 & 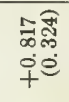 & 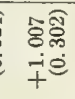 \\
\hline రే & & & & & & & & 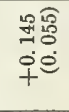 & 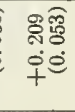 \\
\hline$\frac{1}{4}$ & & & & & & 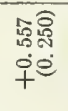 & 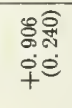 & & \\
\hline 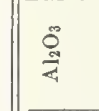 & & 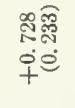 & 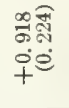 & 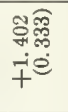 & 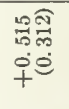 & & & & \\
\hline 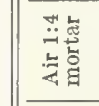 & 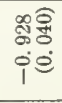 & 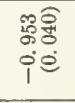 & 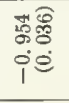 & 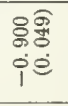 & 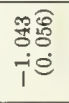 & 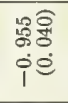 & 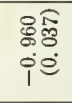 & $\begin{array}{l}\text { rôे } \\
\text { 悉 } \\
\text { ie }\end{array}$ & 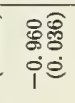 \\
\hline $\begin{array}{l}\overrightarrow{\mathrm{g}} \\
\dot{0} \\
\dot{0}\end{array}$ & 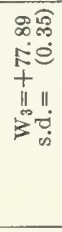 & 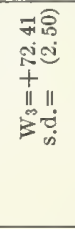 & 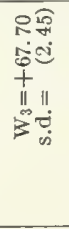 & 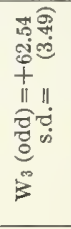 & 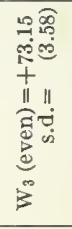 & 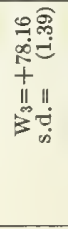 & 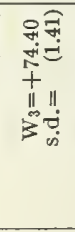 & 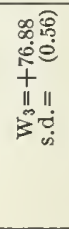 & 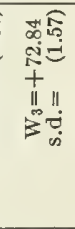 \\
\hline 苋 & $£$ & $\Xi$ & 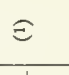 & 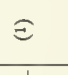 & 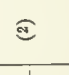 & $£$ & $\widehat{\varrho}$ & $\widehat{\varepsilon}$ & 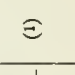 \\
\hline 象总 & $\begin{array}{l}\underbrace{}_{4} \\
z \\
+ \\
\mathbf{9} \\
\end{array}$ & : & $\frac{1}{1}$ & 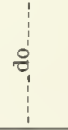 & $\stackrel{8}{0}$ & 용 & 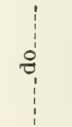 & $\stackrel{8}{8}$ & $\stackrel{8}{8}$ \\
\hline 总: & $\rightarrow$ & $\infty$ & $\infty$ & 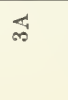 & 品 & $r$ & 10 & 0 & $n$ \\
\hline
\end{tabular}




\begin{tabular}{|c|c|c|c|c|c|c|c|c|c|}
\hline$\stackrel{\dot{Q}}{\dot{D}}$ & \begin{tabular}{l}
$F$ \\
\multirow{\infty}{*}{} \\
- \\
-
\end{tabular} & $\begin{array}{l}\text { 亲 } \\
-i\end{array}$ & 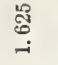 & 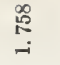 & $\begin{array}{l}\text { 哭 } \\
\text { : } \\
-1\end{array}$ & $\begin{array}{l}\text { 怘 } \\
\text { - }\end{array}$ & $\begin{array}{l}80 \\
8 \\
-1\end{array}$ & 苦 & $\stackrel{0}{0}$ \\
\hline 2 & & & $\begin{array}{l}\text { ণ્લิ } \\
\text { i. }\end{array}$ & 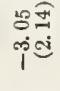 & $\begin{array}{l}\text { 5. } \\
\text { id } \\
\text { i. }\end{array}$ & & 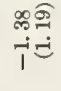 & & $\begin{array}{l}10 \widehat{0} \\
i= \\
i=\end{array}$ \\
\hline $\overrightarrow{\partial_{1}}$ & & & 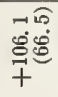 & 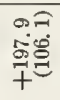 & 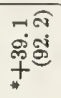 & & $\begin{array}{l}\infty \hat{\sigma} \\
\text { mis } \\
+ \\
+\end{array}$ & & $\begin{array}{l}\text { +क } \\
\text { अध } \\
7 \\
7\end{array}$ \\
\hline$>$ & & & $\begin{array}{l}0 \widehat{0} \\
\stackrel{5}{+} \\
+\end{array}$ & $\begin{array}{l}\text { of } \\
\text { ลี్่ } \\
+\end{array}$ & $\overrightarrow{+}$ & & $\begin{array}{l}\sim \sqrt{\infty} \\
\infty \\
+\infty \\
+\end{array}$ & & 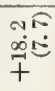 \\
\hline$\vec{F}$ & & & 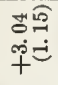 & $\begin{array}{l}n \infty \\
r_{0}^{\infty} \\
\text { ac } \\
+\end{array}$ & 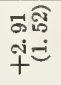 & & 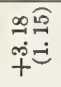 & & 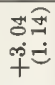 \\
\hline$\tilde{0}$ & & & 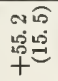 & 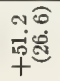 & 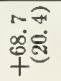 & & $\begin{array}{l}\cos \\
\infty \\
+\infty \\
+\infty\end{array}$ & & 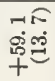 \\
\hline $\begin{array}{l}\overline{\bar{O}} \\
\bar{G} \\
\bar{g}\end{array}$ & & $\begin{array}{l}\text { Fैत्ड } \\
\text { iं }\end{array}$ & $\begin{array}{l}\text { ins } \\
\text { iอ }\end{array}$ & 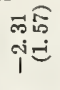 & 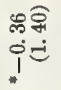 & 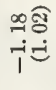 & $\begin{array}{l}\text { is } \\
\text { ie }\end{array}$ & $\begin{array}{l}\text { मृब } \\
-i d\end{array}$ & $\begin{array}{l}\hat{0} \mathscr{8} \\
i \mathfrak{j}\end{array}$ \\
\hline$\frac{5}{4}$ & & 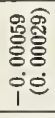 & 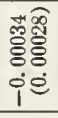 & 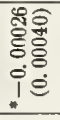 & 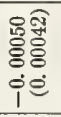 & 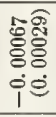 & 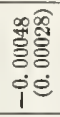 & 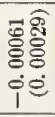 & 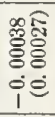 \\
\hline 总 & & 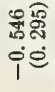 & 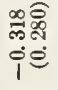 & 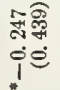 & 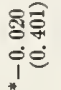 & 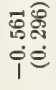 & 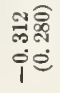 & 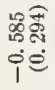 & 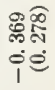 \\
\hline $\begin{array}{l}\text { О्ञ } \\
\text { zึ. }\end{array}$ & & & & & & & & & \\
\hline $\begin{array}{l}0 \\
\substack{B 0 \\
\sum}\end{array}$ & & 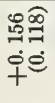 & 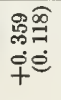 & 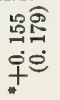 & 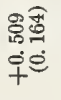 & 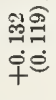 & 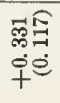 & 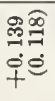 & 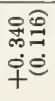 \\
\hline$\left.\infty\right|_{\frac{1}{4}} ^{+}$ & & 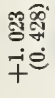 & 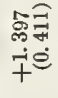 & 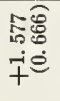 & 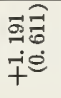 & 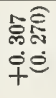 & 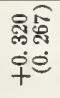 & 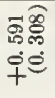 & 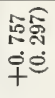 \\
\hline ర్ & & & & & & & & 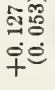 & 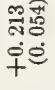 \\
\hline$\sum_{4}^{2}$ & & & & & & & $\begin{array}{l}\text { के } \\
\text { †ं }\end{array}$ & & \\
\hline 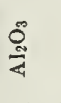 & & 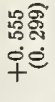 & 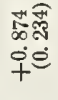 & 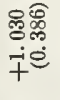 & 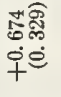 & & & & \\
\hline 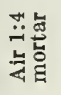 & 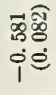 & $\begin{array}{l}\infty 0 \\
\stackrel{0}{0} \% \\
i 0 \\
10\end{array}$ & 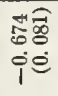 & 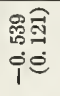 & $\begin{array}{l}0 \widehat{0} \\
\infty 0 \\
00 \\
0\end{array}$ & 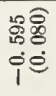 & 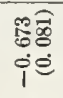 & 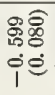 & 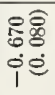 \\
\hline $\begin{array}{l}\overrightarrow{\mathrm{g}} \\
\text { हु }\end{array}$ & 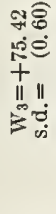 & 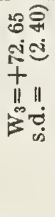 & 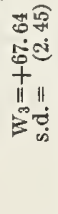 & 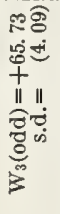 & 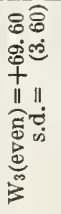 & 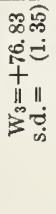 & 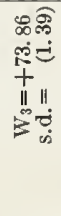 & 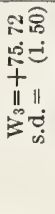 & 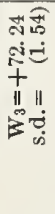 \\
\hline 芩 & $\approx$ & $\approx$ & $\approx$ & 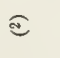 & ๔ & $£$ & $\lesssim$ & 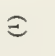 & $\hat{\Xi}$ \\
\hline 营 & 穵 & $\stackrel{0}{\frac{0}{1}}$ & \% & $\frac{0}{1}$ & 8 & 8 & ஜீ & $\frac{0}{1}$ & $\stackrel{0}{0}$ \\
\hline 总泀 & $\infty$ & os & $\cong$ & $\overleftrightarrow{\varrho}$ & $\stackrel{\check{\sigma}}{\sigma}$ & $\Rightarrow$ & $\stackrel{\mathcal{I}}{\mathcal{I}}$ & 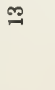 & $\Rightarrow$ \\
\hline
\end{tabular}

present in eqs (1) through (7) but not in (8) through (14) where the coef/s.d. ratios for these variables when tried were less than 1 . Including the trace elements in the computed equations decreased the coef./s.d. ratio of the loss on ignition to less than one with the $\mathrm{AE}+\mathrm{NAE}$ cements, but not with the NAE cements, although the coefficients were reduced to some extent in the latter case. The coefficients of other variables such as $\mathrm{Al}_{2} \mathrm{O}_{3}, \mathrm{~A} / \mathrm{F}, \mathrm{C}_{3} \mathrm{~A}$, and $\mathrm{S} /(\mathrm{A}+\mathrm{F})$ were larger with the use of the trace elements than without them and the coefficient for APF was smaller in magnitude.

The S.D. values obtained for the equations in table $2-10$ were approximately the same as the standard deviation value of the water used for standard consistency of the 1:4 mortars in the regularly conducted interlaboratory tests on another series of cements mentioned previously.

Using approximate ranges of the independent variables determined from values presented in table 2-1 and the coefficients of eq (3) of table 2-10, the calculated contributions to the amount of water required for standard consistency of the 1:4 cement to 20-30 Ottawa sand mortars are presented, together with the ranges of such contributions, in table $2-11$.

\subsection{Concrete Made With a Constant Water-Cement Ratio}

The frequency distribution of the cements with respect to slump values when concrete was made with a water-cement ratio of 0.635 is presented in table 2-12 and the frequency distribution with respect to the air content of these concretes is presented in table 2-13. The slump values ranged from 2.0 to $8.5 \mathrm{in}$. and the air-content values ranged from 0.5 to 10.5 percent.

TABLE 2-11. Calculated contribution of independent variables to the amount of water used for 1:4 mortars of standard consistency and the calculated ranges of such contributions

\begin{tabular}{|c|c|c|c|c|}
\hline $\begin{array}{l}\text { Independent } \\
\text { variable }\end{array}$ & $\begin{array}{l}\text { Range of } \\
\text { variable }\end{array}$ & $\begin{array}{c}\text { Coefficients } \\
\text { from eq }(3) \\
\text { of table } \\
2-10\end{array}$ & $\begin{array}{c}\text { Calculated } \\
\text { contribution } \\
\text { to } \mathrm{W}_{3}\end{array}$ & $\begin{array}{l}\text { Calculated } \\
\text { range of } \\
\text { contribu- } \\
\text { tion to } \mathrm{W}_{3}\end{array}$ \\
\hline $\begin{array}{l}\text { Air Content } \\
1: 4 \text { Mortar } \\
\mathrm{Al}_{2} \mathrm{O}_{3} \\
\mathrm{~S} /(\mathrm{A}+\mathrm{F}) \\
\mathrm{MgO} \\
\mathrm{Na} \mathrm{O} \\
\mathrm{APF} \\
\text { Insol. res } \\
\mathrm{Cu} \\
\mathrm{Ti} \\
\mathrm{V} \\
\mathrm{Rb} \\
\mathrm{Zr}\end{array}$ & $\begin{array}{lll}1 & \text { to } 24 \% \\
2.5 & \text { to } & 7.5 \% \\
1.8 & \text { to } 4.2 \% \\
0 & \text { to } 5.0 \% \\
0 & \text { to } 0.7 \% \\
3000 & \text { to } 5500 \\
0 & \text { to } 1.0 \% \\
0 & \text { to } 0.05 \% \\
.05 & \text { to } 1.0 \% \\
0 & \text { to } 0.1 \% \\
0 & \text { to } 0.01 \% \\
0 & \text { to } 0.5 \%\end{array}$ & $\begin{array}{c}-0.954 \\
+0.918 \\
+1.712 \\
+0.399 \\
+2.12 \\
-0.00041 \\
-1.72 \\
+66.3 \\
+3.36 \\
+18.5 \\
+161.6 \\
-4.81\end{array}$ & $\begin{array}{r}\text { const. }=67.7 \\
-1.0 \text { to }-22.9 \\
+2.3 \text { to }+6.9 \\
+3.1 \text { to }+7.2 \\
0 \text { to }+2.0 \\
0 \text { to }+1.5 \\
-1.2 \text { to }-2.3 \\
0 \text { to }-1.7 \\
0 \text { to }+3.3 \\
0.2 \text { to }+3.4 \\
0 \text { to }+1.8 \\
0 \text { to }+1.6 \\
0 \text { to }-2.4\end{array}$ & $\begin{array}{l}21.9 \\
4.6 \\
4.1 \\
2.0 \\
1.5 \\
1.1 \\
1.7 \\
3.3 \\
3.2 \\
1.8 \\
1.6 \\
2.4\end{array}$ \\
\hline
\end{tabular}

In figure $2-1$ is presented a plot, made by averaging groups as previously described [6], of the values of slump of the concretes versus the percentage water used for standard consistency of the $1: 2.75$ mortars. The value of -13 for the "quadrant-sum" of this plot would indicate a 98 percent probability of a significant relationship. The significance of this relationship is probably 
TABLE 2-12. Frequency distribution of cements with respect to slump of concrete made with a water cement ratio of 0.635

\begin{tabular}{|c|c|c|c|c|c|c|c|c|c|c|c|c|c|c|c|}
\hline \multirow{3}{*}{ Type cement } & \multicolumn{14}{|c|}{ Slump, inches } & \multirow{3}{*}{ Total } \\
\hline & $\begin{array}{l}2.0 \text { to } \\
2.5\end{array}$ & $\begin{array}{c}2.5 \text { to } \\
3.0\end{array}$ & $\begin{array}{c}3.0 \text { to } \\
3.5\end{array}$ & $\begin{array}{c}3.5 \text { to } \\
4.0\end{array}$ & $\begin{array}{c}4.9 \text { to } \\
4.5\end{array}$ & $\begin{array}{c}4.5 \text { to } \\
5.0\end{array}$ & $\begin{array}{c}5.0 \text { to } \\
5.5\end{array}$ & $\begin{array}{l}5.5 \text { to } \\
6.0\end{array}$ & $\begin{array}{l}6.0 \text { to } \\
6.5\end{array}$ & $\begin{array}{l}6.5 \text { to } \\
7.0\end{array}$ & $\begin{array}{l}7.0 \text { to } \\
7.5\end{array}$ & $\begin{array}{l}7.5 \text { to } \\
8.0\end{array}$ & $\begin{array}{l}8.0 \text { to } \\
8.5\end{array}$ & \begin{tabular}{|c|}
8.5 to \\
9.0
\end{tabular} & \\
\hline & \multicolumn{14}{|c|}{ Number of cements } & \\
\hline I & 9 & 13 & 18 & 12 & 11 & 4 & 3 & 3 & 5 & 2 & 2 & & & & 82 \\
\hline $\begin{array}{l}\text { IA } \\
\text { II }\end{array}$ & 1 & 5 & 9 & 15 & 5 & 2 & 4 & 9 & 5 & $\begin{array}{l}1 \\
6\end{array}$ & $\begin{array}{l}4 \\
5\end{array}$ & 2 & $\cdots$ & 1 & $\begin{array}{r}8 \\
68\end{array}$ \\
\hline IIA & & & & & & & & & 0 & 1 & & 1 & $\tilde{i}^{-}$ & - n & 3 \\
\hline III-_-_.......... & 1 & 5 & 6 & -........ & 2 & 2 & --- & 3 & - & & 1 & - & & --.--- & 20 \\
\hline$I V$ and $V$ & (n) & ( n & 4 & (n) & $\overline{1}$ & $\overline{1}$ & 2 & 1 & 1 & 2 & $\begin{array}{l}1 \\
2\end{array}$ & $\begin{array}{l}1 \\
1\end{array}$ & $|-\cdots+\infty|$ & ( & $\begin{array}{r}3 \\
15\end{array}$ \\
\hline Total .... & 11 & 23 & 37 & 27 & 19 & 9 & 9 & 16 & 12 & 12 & 15 & 7 & 1 & 1 & 199 \\
\hline
\end{tabular}

TABLE 2-13. Frequency distribution of percentage air in concretes of water cement ratio of 0.635

\begin{tabular}{|c|c|c|c|c|c|c|c|c|c|c|c|c|c|}
\hline \multirow{3}{*}{ Type cement } & \multicolumn{13}{|c|}{ Percentage air } \\
\hline & \begin{tabular}{|c}
0 \\
to \\
0.5
\end{tabular} & $\begin{array}{l}0.5 \\
\text { to } \\
1.0\end{array}$ & $\begin{array}{l}1.0 \\
\text { to } \\
1.5\end{array}$ & $\begin{array}{c}1.5 \\
\text { to } \\
2.0\end{array}$ & $\begin{array}{l}2.0 \\
\text { to } \\
2.5\end{array}$ & \begin{tabular}{|c|}
2.5 \\
to \\
3.0
\end{tabular} & $\begin{array}{c}3.0 \\
\text { to } \\
3.5\end{array}$ & \begin{tabular}{|c|}
3.5 \\
to \\
4.0
\end{tabular} & $\begin{array}{l}4.0 \\
\text { to } \\
4.5\end{array}$ & $\begin{array}{c}4.5 \\
\text { to } \\
5.0\end{array}$ & $\begin{array}{c}5.0 \\
\text { to } \\
7.0\end{array}$ & $\begin{array}{c}7.0 \\
\text { to } \\
9.0\end{array}$ & $\begin{array}{c}9.0 \\
\text { to } \\
11.0\end{array}$ \\
\hline & \multicolumn{13}{|c|}{ Number of cements } \\
\hline$I_{-}$ & 2 & 8 & 15 & 26 & 17 & 11 & 2 & -..- & 1 & & & 7 & 1 \\
\hline II & 1 & 16 & 22 & 16 & $\overrightarrow{6}$ & 3 & 1 & $2-$ & $\ldots$ & 1 & & $r$ & 1 \\
\hline IIA & & & & & & & & & & & 1 & 2 & \\
\hline III_- & -- & 2 & 8 & 6 & 1 & 2 & $-\ldots$ & 1 & & & & & \\
\hline IV and $V_{-. . .}$ & ( & -2 & 6 & -5 & $\mid--1$ & $-\overline{2}$ & & & & & 1 & 2 & \\
\hline Totals _ & 3 & 28 & 51 & 53 & 24 & 18 & 3 & 3 & 1 & 1 & 2 & 11 & 1 \\
\hline
\end{tabular}

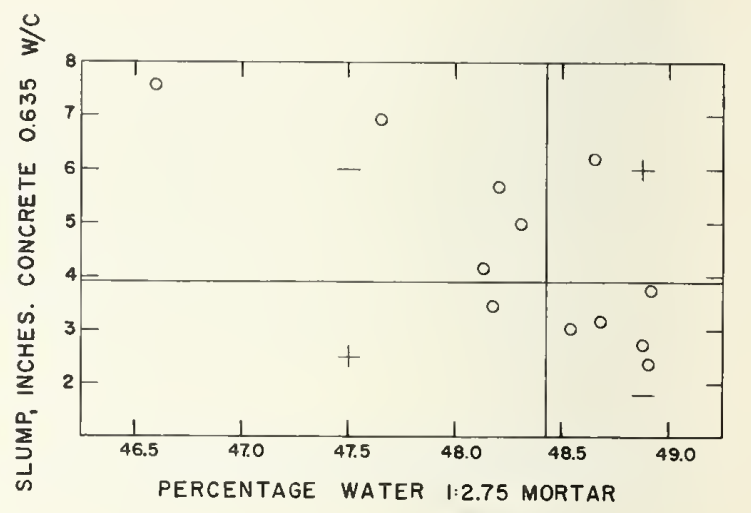

FIGURE 2-1. Results of plotting 12 pairs of averages of slump of concretes made with a water-cement ratio of 0.635 versus the percentage water used for the 1:2.75 cement to graded Ottawa sand mortar.

(The ratio of points in opposite quadrants $=10 / 2$ and the quadrant sum $=-13$ See section 4.1 of section 1 [ref. 6])

TABLE 2-14. Coefficients of equations relating the slump and air contents of concretes made with a water-cement ratio of 0.635 to various independent variables

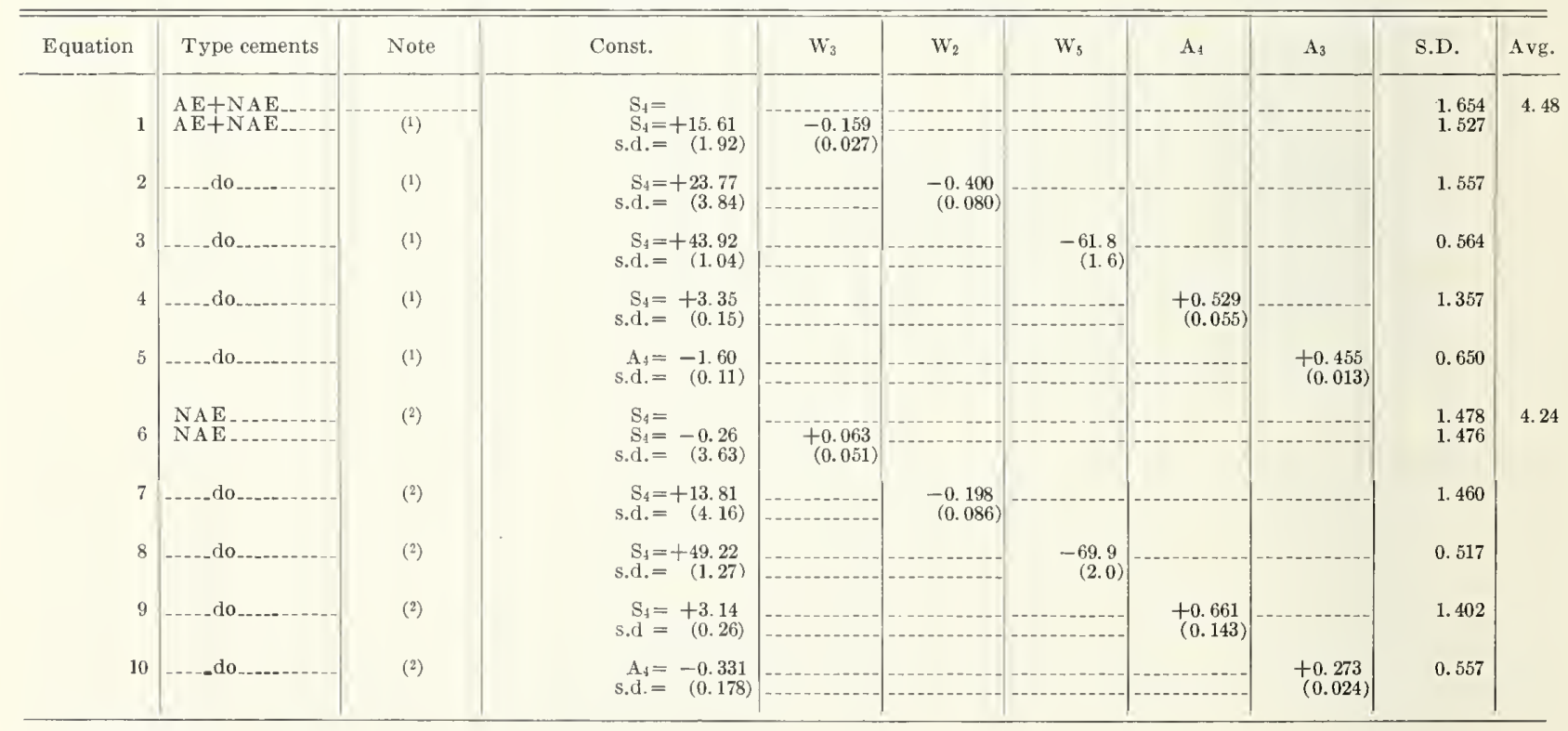

1190 cements. 


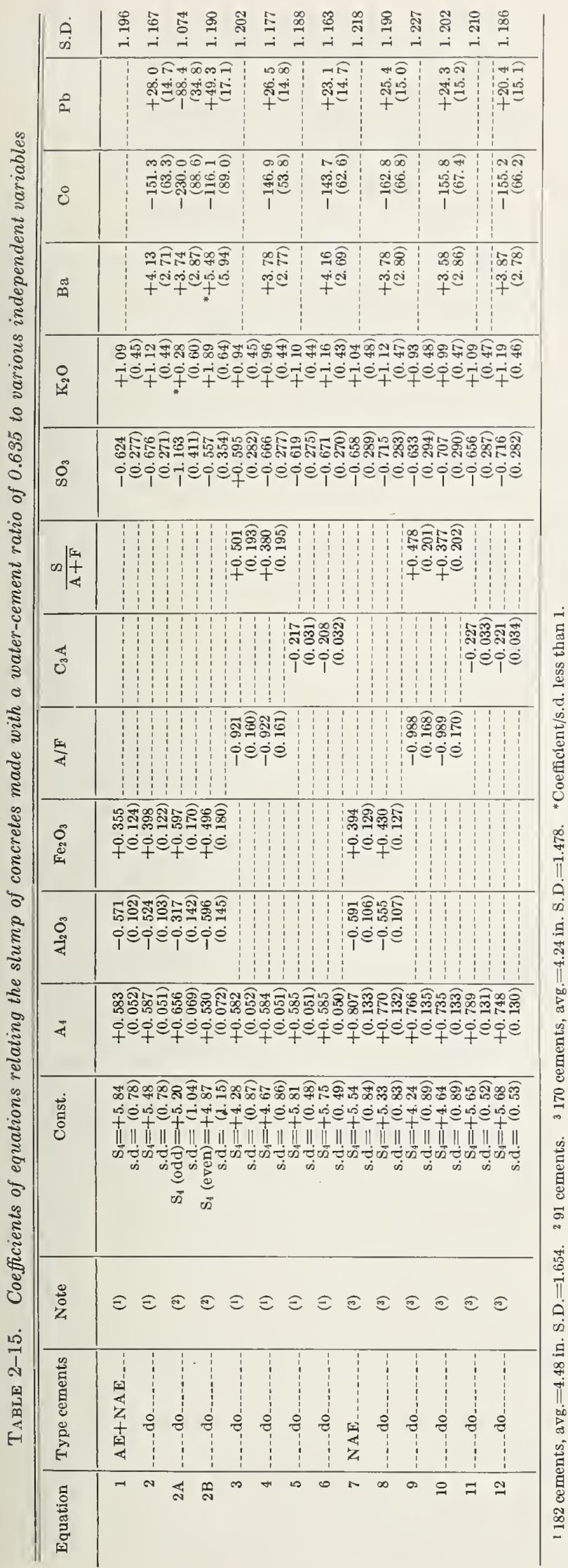

enhanced by the fact that the air-entraining cements had greater slump values and lower water requirements for standard consistency of the 1:2.75 mortars than did the NAE cements. For example, all of the $14 \mathrm{AE}$ cements are included in the group of 16 represented by the point at 46.6 percent water and 7.5 percent air in the upper left corner of figure $2-1$.

The average value for slump for the $\mathrm{AE}+\mathrm{NAE}$ cements was 4.48 in. with an S.D. value of 1.654 . For the NAE cements the average was 4.24 in. with an S.D. value of 1.478 . The average for the 12 AE cements was 7.88. In table 2-14 are presented the coefficients of equations expressing the relationship of the slump values of the 0.635 $\mathrm{W} / \mathrm{C}$ ratio concrete to the percentages of water used for standard consistency of the 1:4 mortars $\left(W_{3}\right)$ and the $1: 2.75$ mortars $\left(W_{2}\right)$, and the watercement ratio used for the $5 \pm 1$-in. slump concretes $\left(W_{5}\right)$. A high degree of correlation existed between the slump values obtained with the 0.635 W/C ratio concrete and the water used for the $5 \pm 1$-in. slump concrete (eqs (3) and (8), table 2-14). Slump of the constant-water-cement-ratio concrete was related significantly to water requirements of the $1: 4$ or $1: 2.75$ mortars $\left(W_{3}\right.$ and $W_{2}$, respectively) except for the case of the $1: 2.75$ mortars with NAE cements (eq (6)) .

The equations indicating the relationship of the various independent variables to the slump of the $0.635 \mathrm{~W} / \mathrm{C}$ concretes are presented in table $2-15$. Comparing eqs (1), (3), and (5) of table 2-15 with eq (4) of table 2-14 it may be noted that the S.D. values were lower when certain commonly determined variables were included with the air content of the concrete in solving the equations. This was also true for the NAE cements, eqs (7), (9), and (11) of table 15, as compared with eq (9) of table 2-14. Inclusion of the elements $\mathrm{Ba}, \mathrm{Co}$, and $\mathrm{Pb}$ present in minor quantities in the cements significantly reduced the S.D. values of the equations in each instance (table 2-22). The effect of using the "odd" and "even" cements is indicated in eqs (2A) and (2B) in table 2-15.

Again using the approximate ranges of the independent variables obtained from values presented in table $2-1$ and the coefficients presented in eq (2) of table 2-15 the calculated contributions to the slump of the $0.635 \mathrm{~W} / \mathrm{C}$ ratio concretes together with the ranges of such contributions are presented in table 2-16. The coefficient for $\mathrm{Pb}$ in eq $(2 \mathrm{~A})$ is negative, while in eqs (2) and (2B) it is positive, and in all three cases the coefficient is significantly larger than its S.D. value. The reason for this discrepancy is that there were only 31 finite values of $\mathrm{Pb}$, the rest being below the reporting limit and being recorded as zero. The split of finite values between the odds and evens was by chance not uniform and therefore did not produce results in agreement with eq (2) calculated from the total number.

Concretes made with 29 of the cements used in this program of tests had slump values in the 
TABLE 2-16. Calculated contribution of independent variables to the slump of concrete made with a watercement ratio of 0.635 and the calculated ranges of such contributions

\begin{tabular}{|c|c|c|c|c|}
\hline $\begin{array}{c}\text { Independent } \\
\text { variable }\end{array}$ & $\begin{array}{l}\text { Range of } \\
\text { variable } \\
\text { (percent) }\end{array}$ & $\begin{array}{c}\text { Coeffi- } \\
\text { cients from } \\
\text { eq. (2) of } \\
\text { table } 2-15\end{array}$ & $\begin{array}{c}\text { Calculated } \\
\text { contribution } \\
\text { to } \mathrm{S}_{4}\end{array}$ & $\begin{array}{l}\text { Calculated } \\
\text { range of } \\
\text { contribu- } \\
\text { tion to } S_{4}\end{array}$ \\
\hline $\begin{array}{l}\text { Air in concrete } \\
\mathrm{Al}_{2} \mathrm{O}_{3} \\
\mathrm{Fe}_{2} \mathrm{O}_{3} \\
\mathrm{SO}_{3} \\
\mathrm{~K}_{2} \mathrm{O} \\
\mathrm{Ba} \\
\mathrm{Co} \\
\mathrm{Pb}\end{array}$ & $\begin{array}{ll}0 & \text { to } 10 \\
2.5 & \text { to } \\
1.0 & \text { to } 5.5 \\
1.4 & \text { to } 3.0 \\
0 & \text { to } 1.1 \\
0 & \text { to } 0.20 \\
0 & \text { to } 0.01 \\
0 & \text { to } 0.05\end{array}$ & $\begin{array}{c}+0.587 \\
-0.524 \\
+0.398 \\
-0.676 \\
+1.12 \\
+4.13 \\
-151.3 \\
+28.0\end{array}$ & $\begin{array}{c}\text { const. }=5.48 \\
0 \text { to }+5.9 \\
-1.3 \text { to }-3.9 \\
+0.4 \text { to }+2.0 \\
-0.9 \text { to }-2.0 \\
0 \text { to }+1.2 \\
0 \text { to }+0.8 \\
0 \text { to }-1.5 \\
0 \text { to }+1.4\end{array}$ & $\begin{array}{l}5.9 \\
2.6 \\
1.6 \\
1.1 \\
1.2 \\
0.8 \\
1.5 \\
1.4\end{array}$ \\
\hline
\end{tabular}

$5 \pm 1$-in. range in the first series of concretes, which had a constant water-cement ratio of 0.635 and also had the same $\mathrm{W} / \mathrm{C}$ ratio in the second series. The duplicate batches of concrete made from these cements for the second series of concrete tests thus afford a means for evaluating the reproducibility of the slump values and the aircontent values. The standard deviation computed from the 29 pairs of slump values was 0.46 which was significantly smaller than the S.D. values presented in table $2-15$. The pairs of values of each of the cements were usually determined the same day and with sand and gravel from the same shipments, whereas the making of concretes from a majority of the different cements was made during a period of 2 years, with only a few concretes made 3 and 4 years from the start of the test series. A number of shipments of sand and gravel were obtained in this period.

The air-content values of the 29 pairs of deter-
TABLE 2-17. Frequency distribution of water cement ratios required for concrete with $5 \pm 1$ in. slump

\begin{tabular}{|c|c|c|c|c|c|c|c|c|}
\hline \multirow{3}{*}{ Type cement } & \multicolumn{7}{|c|}{ Water cement ratio } & \multirow{3}{*}{ Total } \\
\hline & $\begin{array}{c}0.550 \\
\text { to } \\
0.575\end{array}$ & $\begin{array}{c}0.575 \\
\text { to } \\
0.600\end{array}$ & $\begin{array}{c}0.600 \\
\text { to } \\
0.625\end{array}$ & $\begin{array}{c}0.625 \\
\text { to } \\
0.650\end{array}$ & $\begin{array}{c}0.650 \\
\text { to } \\
0.675\end{array}$ & $\begin{array}{c}0.675 \\
\text { to } \\
0.700\end{array}$ & $\begin{array}{c}0.700 \\
\text { to } \\
0.725\end{array}$ & \\
\hline & \multicolumn{7}{|c|}{ Number of cements } & \\
\hline IA & 4 & 4 & 5 & 32 & 34 & 7 & 1 & $\begin{array}{r}79 \\
8\end{array}$ \\
\hline II & 4 & $\Psi$ & 15 & 29 & 22 & 1 & -- & 67 \\
\hline $\begin{array}{l}\text { IIA } \\
\text { III. }\end{array}$ & 1 & 1 & $\begin{array}{l}1 \\
2\end{array}$ & 6 & ii & -1 & & $\begin{array}{r}3 \\
20\end{array}$ \\
\hline IIIA & ...... & 2 & 1 & & & & & 3 \\
\hline IV and $V_{--}$ & & & 6 & 6 & 3 & $\ldots$ & $\mid-\ldots$ & 15 \\
\hline Total_.. & 5 & 7 & 30 & 73 & 70 & 9 & 1 & 195 \\
\hline
\end{tabular}

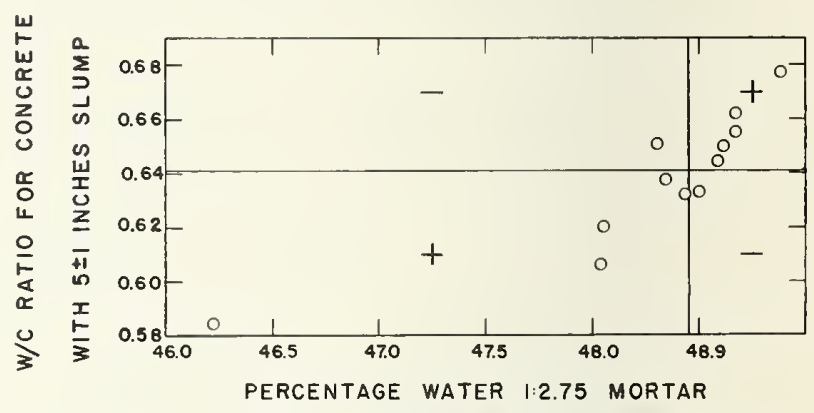

FIGURE 2-2. Results of plotting 12 pairs of averages of water-cement ratio used for concretes having a $5 \pm 1$-inch slump versus the percentage water used for the 1:2.75 cement to graded Ottawa sand mortar.

(The ratio of points in opposite quadrants $=10 / 2$ and the quadrant sum $=$ +15 . See section 4.1 of section 1 [ref. 6])

\begin{tabular}{|c|c|c|c|c|c|c|c|c|c|c|c|c|c|c|c|c|c|c|c|}
\hline \multirow{2}{*}{\begin{tabular}{|c|}
$\begin{array}{c}\text { OEPENOENT } \\
\text { VARAAELE }\end{array}$ \\
WATER \\
REOURREMENTS
\end{tabular}} & \multicolumn{19}{|c|}{ INDEPENDENT VARIABLES } \\
\hline & NOTE & $\mathrm{s}_{\mathrm{i}} \mathrm{O}_{2}$ & $\mathrm{Al}_{2} \mathrm{O}_{3}$ & $\mathrm{Fe}_{2} \mathrm{O}_{3}$ & $\mathrm{C}_{\mathrm{a}} \mathrm{O}$ & $M_{0} O$ & $\mathrm{SO}_{3}$ & $\mathrm{Na}_{2} \mathrm{O}$ & $\mathrm{K}_{2} \mathrm{O}$ & $\begin{array}{l}\text { TOTAL } \\
\text { ALKALI }\end{array}$ & $c_{3} A$ & $c_{3} \mathrm{~s}$ & $c_{2} s$ & $\mathrm{C}_{4} \mathrm{AF}$ & $\frac{A}{F}$ & $\frac{s}{A+F}$ & $\begin{array}{l}\text { AIR P. } \\
\text { FINE }\end{array}$ & $\begin{array}{l}\text { WAGN. } \\
\text { FINE }\end{array}$ & $\begin{array}{l}\text { AIR } \\
1.4 \text { MORT }\end{array}$ \\
\hline \multirow{2}{*}{$\begin{array}{c}\mathrm{ALL} \\
\mathrm{CEMENTS}\end{array}$} & (1) & $\frac{7}{5}$ & $\frac{8}{4}$ & $\frac{8}{4}$ & $\frac{6}{6}$ & $\frac{6}{6}$ & $\frac{8}{4}$ & $\frac{10}{2}$ & $\frac{8}{4}$ & $\frac{6}{6}$ & $\frac{8}{4}$ & $\frac{6}{6}$ & $\frac{6}{6}$ & $\frac{6}{6}$ & $\frac{10}{2}$ & $\frac{8}{1}$ & $\frac{6}{6}$ & $\frac{8}{4}$ & $\frac{8}{4}$ \\
\hline & $\begin{array}{l}\text { (3) } \\
\text { (4) }\end{array}$ & $\begin{array}{l}L ? \\
+3\end{array}$ & $\begin{array}{l}\text { L? } \\
+1\end{array}$ & $\begin{array}{l}\text { L? } \\
-8\end{array}$ & $\begin{array}{l}\text { No } \\
+7\end{array}$ & $\begin{array}{l}\text { No } \\
-1\end{array}$ & $\stackrel{ㄴ ?}{-1}$ & $\begin{array}{l}L ? \\
+8\end{array}$ & $\begin{array}{l}\text { LL? } \\
-9\end{array}$ & No & $\begin{array}{l}\text { L? } \\
+1\end{array}$ & $\begin{array}{l}\text { No } \\
-2\end{array}$ & $\begin{array}{l}\text { No } \\
-2\end{array}$ & $\begin{array}{l}\text { No } \\
-6\end{array}$ & $\stackrel{L P}{+4}$ & $\begin{array}{l}\text { L? } \\
+2\end{array}$ & $\begin{array}{l}\text { No } \\
-5\end{array}$ & $\begin{array}{l}\text { L? } \\
-6\end{array}$ & $\begin{array}{l}\text { L? } \\
-6\end{array}$ \\
\hline \multirow{2}{*}{$\begin{array}{l}\text { NON-AIR- } \\
\text { ENTRAINING } \\
\text { CEMENTS }\end{array}$} & (1) & $\frac{6}{6}$ & $\frac{8}{4}$ & $\frac{8}{4}$ & $\frac{6}{6}$ & $\frac{8}{4}$ & $\frac{6}{6}$ & $\frac{10}{2}$ & $\frac{8}{4}$ & $\frac{8}{4}$ & $\frac{8}{4}$ & $\frac{8}{4}$ & $\frac{6}{6}$ & $\frac{8}{4}$ & $\frac{8}{4}$ & $\frac{6}{6}$ & $\frac{6}{6}$ & $\frac{6}{6}$ & $\frac{6}{6}$ \\
\hline & $\begin{array}{l}\text { (3) } \\
\text { (4) }\end{array}$ & $\begin{array}{l}\text { No } \\
-3\end{array}$ & $\begin{array}{l}\text { L? } \\
+5\end{array}$ & $\begin{array}{l}\text { L? } \\
-6\end{array}$ & $\begin{array}{l}\text { No } \\
-1\end{array}$ & $\begin{array}{l}\text { L? } \\
+9\end{array}$ & $\begin{array}{l}\text { No } \\
+2\end{array}$ & $\begin{array}{l}\llcorner ? \\
+12\end{array}$ & $\begin{array}{l}\text { L? } \\
-4\end{array}$ & $\begin{array}{l}L ? \\
+6\end{array}$ & $\begin{array}{l}\text { L? } \\
+7\end{array}$ & $\begin{array}{l}\text { L? } \\
-1\end{array}$ & $\begin{array}{l}\text { No } \\
-1\end{array}$ & $\begin{array}{l}\text { L? } \\
-6\end{array}$ & $\begin{array}{l}L ? \\
+7\end{array}$ & $\begin{array}{l}\text { No } \\
+5\end{array}$ & $\begin{array}{l}\text { No } \\
-3\end{array}$ & $\begin{array}{c}\text { No } \\
\text { O }\end{array}$ & $\begin{array}{l}\text { No } \\
+4\end{array}$ \\
\hline \multirow{2}{*}{$\begin{array}{l}\text { NON-AIR- } \\
\text { ENTRAINING } \\
\text { CEMENTS, } \\
\text { ONE LA8 } \\
\text { ONLY }\end{array}$} & (1) & $\frac{8}{4}$ & $\frac{10}{2}$ & $\frac{8}{4}$ & $\frac{6}{6}$ & $\frac{8}{4}$ & $\frac{8}{4}$ & $\frac{8}{4}$ & $\frac{8}{4}$ & $\frac{8}{4}$ & $\frac{12}{0}$ & $\frac{8}{4}$ & $\frac{8}{4}$ & $\frac{6}{6}$ & $\frac{10}{2}$ & $\frac{8}{4}$ & $\frac{8}{4}$ & $\frac{8}{4}$ & $\frac{6}{6}$ \\
\hline & $\begin{array}{l}(3) \\
\text { (4) }\end{array}$ & $\begin{array}{c}\text { L? } \\
0\end{array}$ & $\begin{array}{l}\text { L? } \\
+15\end{array}$ & $\begin{array}{l}\llcorner ? \\
-5\end{array}$ & $\begin{array}{c}\text { No } \\
\text { o }\end{array}$ & $\begin{array}{l}\text { L? } \\
+8\end{array}$ & $\begin{array}{l}\text { L? } \\
-2\end{array}$ & $\begin{array}{l}\text { L? } \\
+7\end{array}$ & $\begin{array}{l}L ? \\
+10\end{array}$ & $\begin{array}{l}L ? \\
+8\end{array}$ & $\begin{array}{c}L \\
+24\end{array}$ & $\begin{array}{l}\text { L? } \\
-7\end{array}$ & $\begin{array}{l}L ? \\
+4\end{array}$ & $\begin{array}{l}\text { No } \\
-5\end{array}$ & +17 & $\begin{array}{l}L ? \\
+5\end{array}$ & $\begin{array}{l}\text { L? } \\
-3\end{array}$ & $\begin{array}{l}\text { L? } \\
-4\end{array}$ & $\begin{array}{l}\text { No } \\
-5\end{array}$ \\
\hline
\end{tabular}

NOTE:

(1) RATIO OF NUMBER OF PLOTTEO POINTS IN PAIRS OF DIAMETRICALLY OPPOSITE QUADRANTS

(2) GENERAL TREND OF LINE DRAWN THROUGH PLOTTEO POINTS.

(3) APPARENT NATURE OF RELATIONSHIP. L=LINEAR, NL = NONLINEAR,

(4) QUADRANT SUM IN CORNER TEST (SEE REF 6).

FIGURE 2-3. Results of plotting water-requirements of 1:2.75 cement to graded Ottawa sand mortars on the " $Y$ " axis versus independent variables on the " $X$ " axis. 
TABLE 2-18. Frequency distribution of air content of concretes made with sufficient water to obtain a $5 \pm 1$ in. slump

\begin{tabular}{|c|c|c|c|c|c|c|c|c|c|c|c|c|c|c|c|c|}
\hline \multirow{3}{*}{ Type cement } & \multicolumn{15}{|c|}{ Air content } & \multirow{3}{*}{ Total } \\
\hline & 0 to .5 & $\begin{array}{l}.5 \text { to } \\
1.0\end{array}$ & $\begin{array}{c}1.0 \text { to } \\
1.5\end{array}$ & $\begin{array}{c}1.5 \text { to } \\
2.0\end{array}$ & $\begin{array}{l}2.0 \text { to } \\
2.5\end{array}$ & $\begin{array}{c}2.5 \text { to } \\
3.0\end{array}$ & $\begin{array}{l}3.0 \text { to } \\
3.5\end{array}$ & $\begin{array}{c}3.5 \text { to } \\
4.0\end{array}$ & $\begin{array}{c}4.0 \text { to } \\
4.5\end{array}$ & $\begin{array}{c}4.5 \text { to } \\
5.0\end{array}$ & $\begin{array}{l}5.0 \text { to } \\
7.0\end{array}$ & $\begin{array}{c}7.0 \text { to } \\
9.0\end{array}$ & $\begin{array}{c}9.0 \text { to } \\
11.0\end{array}$ & $\begin{array}{c}11.0 \text { to } \\
13.0\end{array}$ & $\begin{array}{c}13.0 \text { to } \\
15.0\end{array}$ & \\
\hline & \multicolumn{15}{|c|}{ Number of cements } & \\
\hline JA & 6 & 12 & 18 & 17 & 14 & 9 & 2 & & 1 & & & & & & & 97 \\
\hline & $-\overline{6}$ & 19 & 15 & 16 & 3 & & -- & & $-\overline{1}$ & 1 & 1 & 3 & 3 & & 1 & $\begin{array}{r}8 \\
67\end{array}$ \\
\hline $\begin{array}{l}\text { IIA. } \\
\text { IIII.- }\end{array}$ & -- & -5 & 4 & -5 & - & -- & & - & & & 1 & 1 & & 1 & & 3 \\
\hline IIIA- & $\begin{array}{c}1 \\
-\ldots-\end{array}$ & 0 & 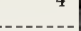 & 0 & 2 & 2 & & & - & - & 2 & 1 & $\ldots$ & -- & - & $\begin{array}{r}20 \\
3\end{array}$ \\
\hline $1 \mathrm{~V}$ and $\mathrm{V}$ & - & 2 & 7 & 3 & 1 & 1 & 1 & --- & $-\cdots$ & -...... & -.. & -.. & & {$[-\ldots-\ldots$} & - & 15 \\
\hline Total & 13 & 38 & 44 & 41 & 20 & 12 & 9 & 1 & 2 & 1 & 4 & 5 & 3 & 1 & 1 & 195 \\
\hline
\end{tabular}

TABLE 2-19. Coefficients of equations relating the water-cement ratio and air content of concretes of $5 \pm 1$-in. slump to various independent variables

\begin{tabular}{|c|c|c|c|c|c|c|c|c|c|}
\hline Equation & Type cements & Note & Const. & $\mathrm{W}_{3}$ & $W_{2}$ & $\mathbf{A}_{3}$ & $\mathbf{A}_{5}$ & S.D. & Avg. \\
\hline 1 & $\begin{array}{l}\mathrm{AE}+\mathrm{NAE} \\
\mathrm{AE}+\mathrm{NAE}\end{array}$ & (1) & $\begin{array}{l}W_{s}= \\
W_{s}=+0.425\end{array}$ & +0.00303 & & | & $\cdots$ & $\begin{array}{l}0.02519 \\
0.02201\end{array}$ & 0.6385 \\
\hline & & & s.d. $=(0.028)$ & $(0.00039)$ & & & & & \\
\hline 2 & --_--do. & (1) & $\begin{array}{c}W_{5}=+0.320 \\
\text { s.d. }=(0.058)\end{array}$ & & $\begin{array}{r}+0.00660 \\
(0.00120)\end{array}$ & & & 0.02342 & \\
\hline 3 & -.... do & (1) & $\begin{array}{l}W_{5}=+0.675 \\
\text { s.d. }=(0.003)\end{array}$ & & & $\begin{array}{c}-0.0045 \\
(0.0004)\end{array}$ & & 0.01905 & \\
\hline 4 & -....do & (1) & $\begin{array}{c}W_{5}=+0.657 \\
\text { s.d. }=(0.002)\end{array}$ & & & & $\begin{array}{c}-0.0091 \\
(0.0006)\end{array}$ & 0.01691 & \\
\hline 5 & -.--do do & (1) & $\begin{array}{c}A_{s}=-2.10 \\
\text { s.d. }=(0.15)\end{array}$ & & & $\begin{array}{r}+0.505 \\
(0.016)\end{array}$ & & 0.826 & \\
\hline 6 & $\begin{array}{l}\text { NAE } \\
\text { NAE.-. }\end{array}$ & $\begin{array}{l}(2) \\
(2)\end{array}$ & $\begin{array}{l}W_{s}= \\
W_{5}=+0.737 \\
\text { s.d. }=(0.048)\end{array}$ & $\begin{array}{r}-0.00131 \\
(0.00068)\end{array}$ & & & & $\begin{array}{l}0.01981 \\
0.01965\end{array}$ & 0.6430 \\
\hline 7 & .....do_. & ${ }^{(2)}$ & $\begin{array}{c}W_{5}=+0.514 \\
\text { s.d. }=(0.056)\end{array}$ & & $\begin{array}{r}+0.00266 \\
(0.00115)\end{array}$ & & & 0.01957 & \\
\hline 8 & -....do. & ${ }^{(2)}$ & $\begin{array}{c}W_{s}=+0.662 \\
s . d .=(0.006)\end{array}$ & & & $\begin{array}{r}-0.00266 \\
(0.00083)\end{array}$ & & 0.01930 & \\
\hline 9 & -..--do_ & $\left({ }^{2}\right)$ & $\begin{array}{c}W_{s}=+0.662 \\
\text { s.d. }=(0.003)\end{array}$ & & & & $\begin{array}{c}-0.0123 \\
(0.0015)\end{array}$ & 0.01678 & \\
\hline 10 & .....do & (2) & $\begin{array}{r}\mathbf{A}_{5}=-0.693 \\
\text { s.d. }=(0.214)\end{array}$ & & & $\begin{array}{r}+0.306 \\
(0.029)\end{array}$ & & 0.669 & \\
\hline
\end{tabular}

1190 Cements. $\quad 2176$ Cements.

minations had an estimated standard deviation of 0.17 .

The regression line indicating the relationship between the slump of the constant water-cement ratio concrete to the water-cement ratio used for the $5 \pm 1$-in. slump concrete (eq (3), table 2-14), had an S.D. value of 0.56 which compared reasonably well with the 0.46 value previously mentioned.

\subsection{Concretes With a Slump of $5 \pm 1$ Inches}

The frequency distribution of the cements with respect to the water-cement ratio used to produce a concrete with $5 \pm 1$ in. slump is presented in table $2-17$ and the frequency distribution with respect to the air content of these concretes is presented in table 2-18. The water-cement ratios ranged from 0.550 to more than 0.700 and the air content ranged from less than 0.5 to more than 13.0 percent.
In figure $2-2$ is presented a plot of the watercement ratios of the $5 \pm 1$-in. slump concrete versus the percentage water used for normal consistency of the 1:2.75 mortars. The "quadrant-sum" value of 15 indicates a high degree of correlation. The air-entraining cements with the low water requirements were for the most part responsible for the point in the lower left corner.

In figure $2-3$ is presented a summary of the the results of plotting the amount of water used for the $1: 2.75$ mortars versus various independent variables. The plots for all cements (AE+NAE) or for the NAE cements based on results obtained from all five laboratories do not (with one exception) indicate any very significant relationships. Using the same technique of plotting and the results obtained only in the one laboratory with the greatest number of tests appeared to indicate that cements having high $\mathrm{Al}_{2} \mathrm{O}_{3}, \mathrm{C}_{3} \mathrm{~A}$, or $\mathrm{A} / \mathrm{F}$ ratios also had high water requirements for the 1:2.75 mortar. 


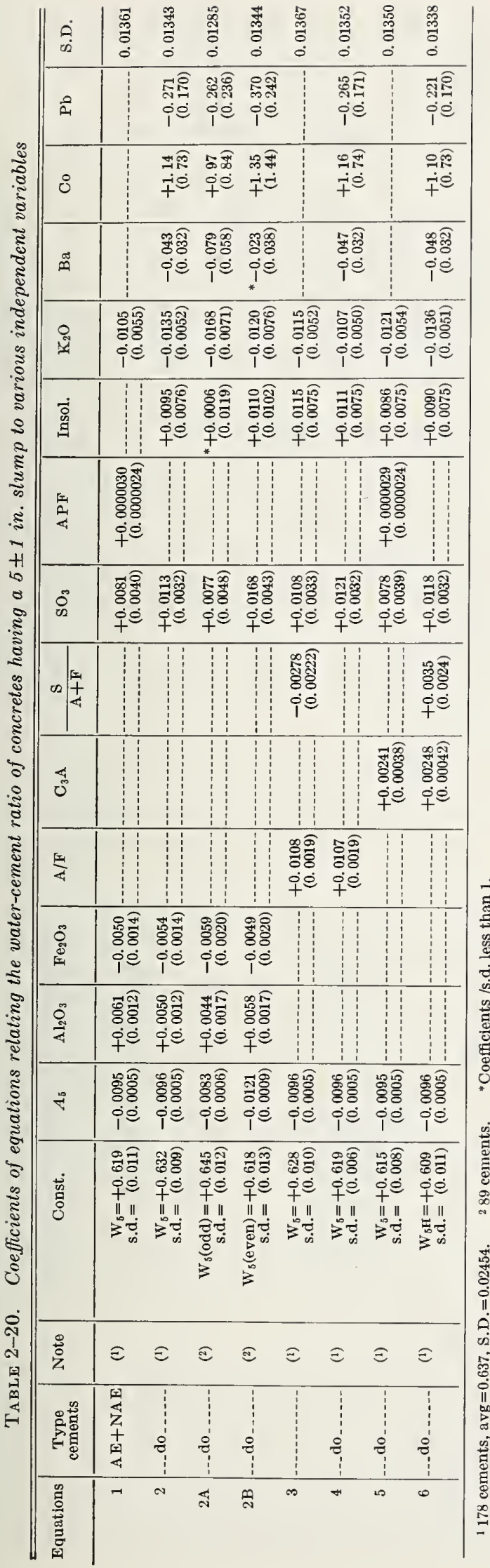

\begin{tabular}{|c|c|c|c|c|c|c|c|c|}
\hline$\stackrel{\dot{\varphi}}{\dot{m}}$ & $\begin{array}{l}\text { : } \\
\text { d. } \\
\text { के } \\
0 \\
0\end{array}$ & $\begin{array}{l}0 \\
\text { J్ } \\
\stackrel{0}{0} \\
0\end{array}$ & $\begin{array}{l}\text { 感 } \\
\text { : }\end{array}$ & $\begin{array}{l}\overrightarrow{7} \\
\text { 总 } \\
0\end{array}$ & $\begin{array}{l}\text { 영 } \\
\text { 영 }\end{array}$ & 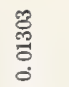 & 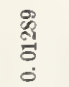 & 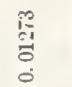 \\
\hline $\overrightarrow{\mathrm{A}_{1}}$ & & 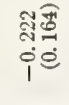 & 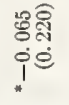 & 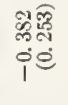 & & 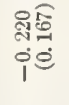 & & $\begin{array}{l}\text { 曾 } \\
\text { is }\end{array}$ \\
\hline 8 & & 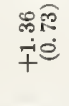 & 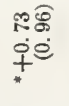 & & & 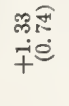 & & 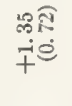 \\
\hline ణొ & & 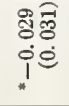 & 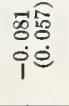 & 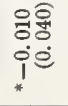 & & & & 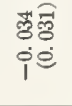 \\
\hline בิ & 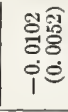 & 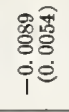 & 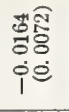 & 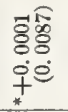 & 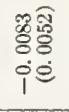 & 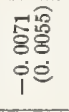 & 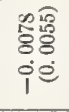 & 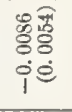 \\
\hline $\begin{array}{l}\dot{0} \\
\text { g. } \\
\text { g }\end{array}$ & & & & & & & & \\
\hline$\frac{\pi}{4}$ & & 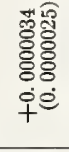 & 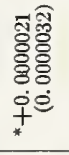 & 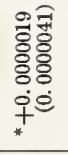 & & 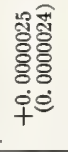 & 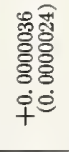 & 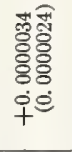 \\
\hline$\stackrel{\infty}{\infty}$ & 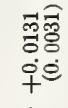 & 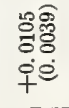 & 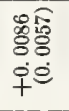 & 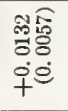 & 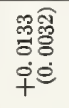 & 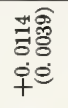 & 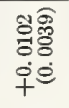 & 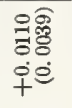 \\
\hline$\left.\infty\right|_{-4} ^{\pi}$ & & & & & 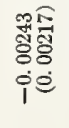 & 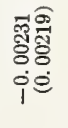 & 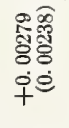 & 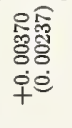 \\
\hline ०े & & & & . & & & 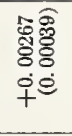 & 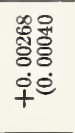 \\
\hline$\frac{\pi}{4}$ & & & & & 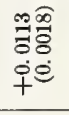 & 逭 & & \\
\hline $\begin{array}{l}0 \\
\text { D. } \\
\text { I }\end{array}$ & 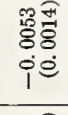 & 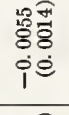 & 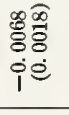 & 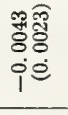 & & & & \\
\hline$\stackrel{3}{4}$ & 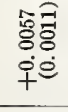 & 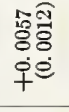 & 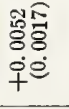 & 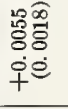 & & & & \\
\hline$\gtrless^{2}$ & 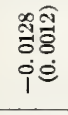 & 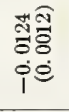 & 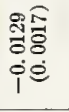 & 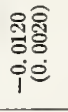 & 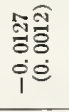 & 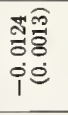 & 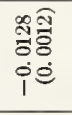 & 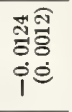 \\
\hline $\begin{array}{l}\vec{\Delta} \\
\overrightarrow{0} \\
\ddot{0}\end{array}$ & 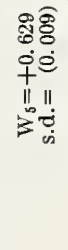 & 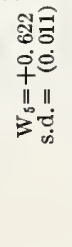 & 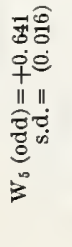 & 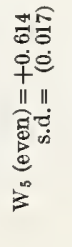 & 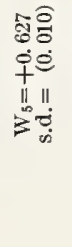 & 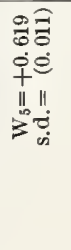 & 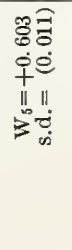 & 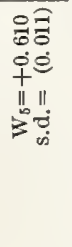 \\
\hline 苂 & 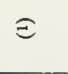 & $\Xi$ & $\lesssim$ & § & $£$ & $\Xi$ & $\Xi$ & 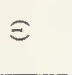 \\
\hline 起总 & $\frac{1}{2}$ & : & $\stackrel{1}{8}$ & 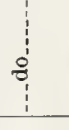 & $\begin{array}{c}i \\
\vdots \\
\vdots \\
\end{array}$ & $\begin{array}{c}\vdots \\
\vdots \\
\vdots \\
\end{array}$ & : & $\begin{array}{c}: \\
\vdots \\
\vdots\end{array}$ \\
\hline 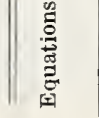 & $n$ & $\infty$ & 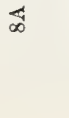 & $\infty_{\infty}^{\infty}$ & $\infty$ & 9 & $\Rightarrow$ & $\cong$ \\
\hline
\end{tabular}


with missing values for any of the independent variables shown in table $2-20$ were eliminated from the calculations in developing the equations in table $2-20$.

The inclusion of commonly determined properties of the cements as variables (eqs (1), (3), and (5) of table 2-20) reduced the S.D. value significantly from that obtained when only the air content was included as in eq (4) of table 2-19.

In table 2-21 are presented the calculated contributions of the various independent variables to the water-cement ratio used in preparing the $5 \pm 1$-in. slump concretes. Although eq (2) did not have the lowest S.D. value in this series it was used as the basis for these calculations because of its conformance with similar previous equations on which these calculations were reported.

\subsection{Calculations on High- and Low-Air Cements}

One of the problems in dealing with these data has been the question of how to treat the $\mathrm{AE}$ cements. Since there were only 14 of these out of the total number of 199 , it was not feasible to calculate regression equations on the $\mathrm{AE}$ cements alone for more than one or two independent variables.

One way of dealing with this situation is to treat the cements as all one population, making calculations on the $\mathrm{AE}+\mathrm{NAE}$ cements, and then to repeat the calculations with the $\mathrm{AE}$ cements eliminated, and to observe the effect of this elimination on the calculated coefficients and standard deviations. This was done throughout this study. However, cements with high air contents whether or not so designated by specifications appear as

TABLE 2-21. Calculated contribution of independent variable to the water-cement ratio used in preparing concretes with a $5 \pm 1$ inch slump and the calculated ranges of such contributions

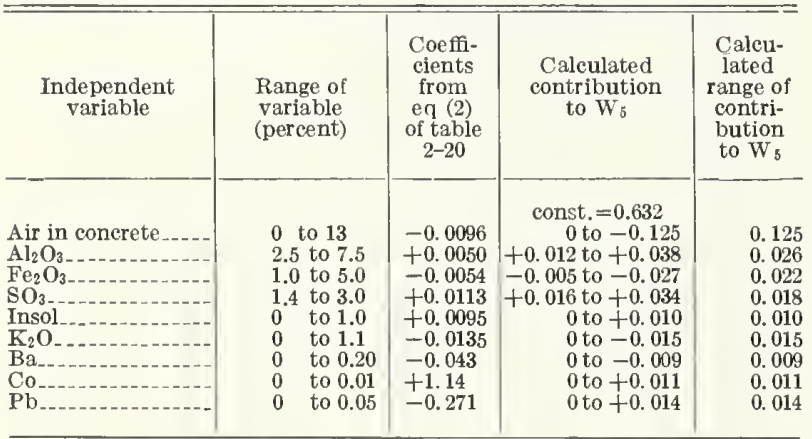

though they belong to a different population with respect to some of the dependent variables, and some other method of treating this situation was desired.

Since the specification limit which divides $\mathrm{AE}$ from NAE cements is more or less arbitrary and has been changed a number of times (see note 3 on page 14), it was felt that using a lower division point for dividing the values into low-air and high-air might be fruitful. For these data, a value of 7.0 percent air in the $1: 4$ mortar was selected, since this was close to the earlier specification limit of 8.0 percent and gave an approximately even split of the data. The group with 7.0 percent air or higher is referred to as the "high-air" group and those with less than 7.0 percent as the "low-air" group.

Separate equations for these two groups were computed for the water requirements for the $1: 2.75$ and $1: 4$ mortars, the concretes of $5 \pm 1$-in. slump and for the slump of the constant-watercement-ratio concretes. The best of these equations are presented in table 2-23. Independent variables with a coef./s.d. ratio of less than 1 were deleted when preliminary trial equations indicated that they were not significant and the various exploratory techniques previously described [6] were employed to find additional independent variables which were then used in fitting each equation.

TABLE 2-22. "F"' values for significance of reduction of variance due to added variables

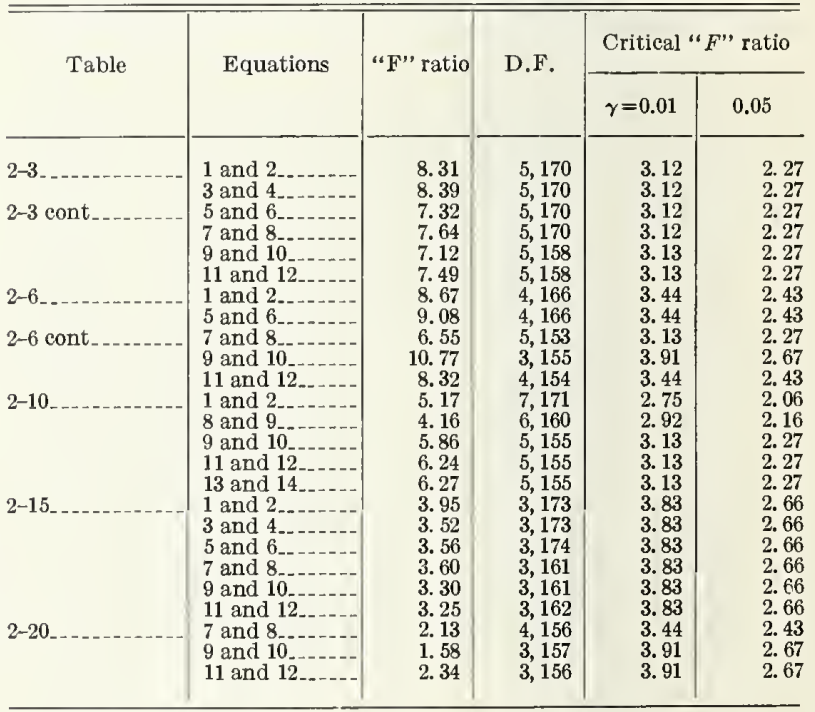

\section{Discussion}

One of the factors which is undoubtedly partly responsible for the comparatively poor correlations between the quantities of water used for pastes, mortars, and concretes is the leeway permitted in specifications. A range of 10 in the percentage flow on the flow table, even for any one skilled operator, permits some range in the percentage water used. Another factor is the nature of the sand which may vary slightly from batch to batch. The flow tables in different laboratories may differ slightly even though calibrated by means of the Cement and Concrete Reference Laboratory flow table mixture. Different skilled operators, although trained to follow specification test methods, may manipulate the mortars in slightly different manners or time their 


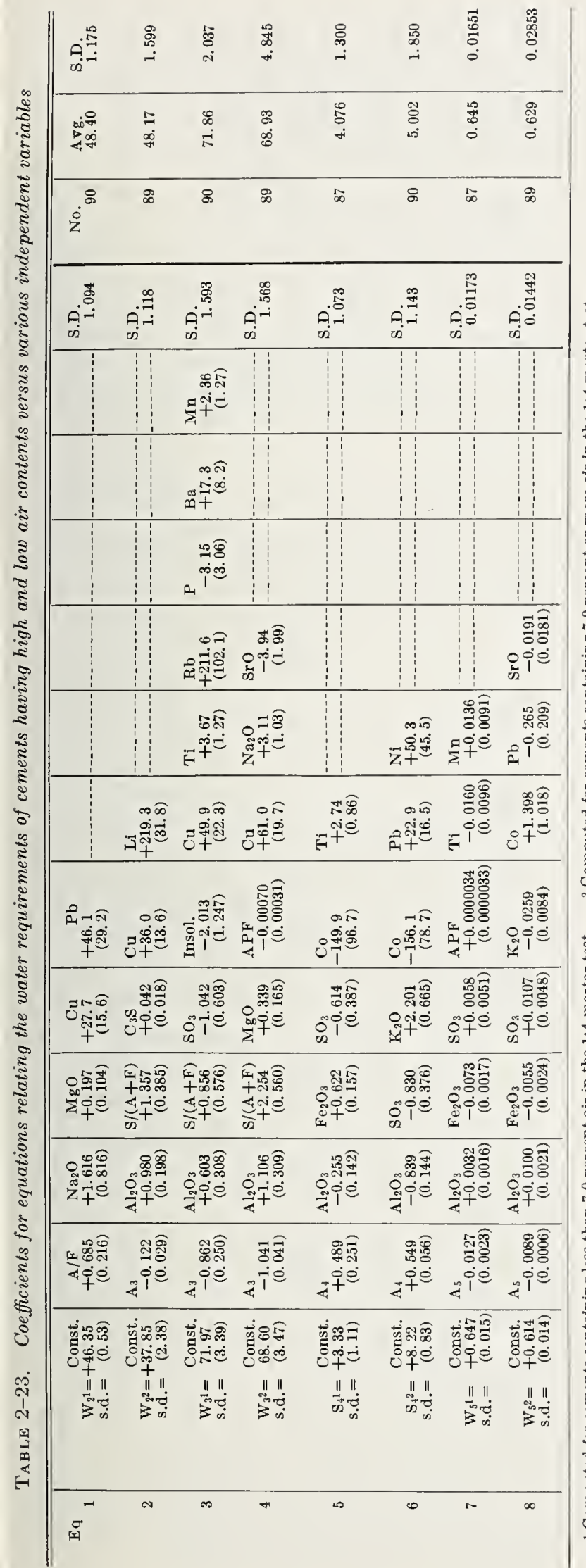

manipulations differently so that the final flow value of the mortar, penetration value of the Vicat needle in the neat paste, or slump value of concrete may not always coincide with values obtained by other operators.

Because of the leeway permitted in determining the amount of water used for a paste, mortar, or concrete together with the variability and inaccuracies associated with the test methods and results as well as the lack of information on certain variables, the effect of some of the independent variables may be masked and there will always be a limit to the degree of fit which can be attained for any set of variables.

As stated in the introduction, the use of different percentages of water in the specification test mortars has been justified on the basis of the relationship to the different water demands of these cements when used in concrete. However, plotting the individual water-requirement values of the mortars against those for the concretes made of the cements in this investigation indicated a rather poor relationship, especially for the non-airentraining cements. This would appear to justify the use of a constant water-cement ratio for the specification compressive strength test mortars. Different values may be considered for use with air-entraining and non-air-entraining cements.

The principal variable in determining the water requirements in the mortars and concretes was the air content of the mortars and concretes. 'This study confirmed that there was a significant relationship between the air contents of the 1:4 mortars and the concretes. It has previously been reported that, for air-entrained concretes, different cements may require different quantities of airentraining agents depending to some extent on their $\mathrm{C}_{3} \mathrm{~A}$ content, in order to obtain the same air content [8]. This present study confirms that the water requirements of the portland cements are related to the chemical characteristics.

The following portion of the discussion deals with the computations made on the $\mathrm{AE}+\mathrm{NAE}$ and on the NAE cements alone. Based on the equations in the tables and subject to the limitations previously discussed [6], it appeared that a number of independent variables were involved. For neat cement pastes, mortars, and concretes, water requirements increased with $\mathrm{Al}_{2} \mathrm{O}_{3}, \mathrm{~A} / \mathrm{F}$ ratio, or $\mathrm{C}_{3} \mathrm{~A}$. The use of any of these three independent variables together with an appropriate group of other variables appeared to have approximately an equal effect on the S.D. values in any one series of equations for the mortars or the concretes. The neat cement pastes which required the greater amounts of water for normal consistency also had higher fineness, $\mathrm{CaO}$, and $\mathrm{SO}_{3}$.

In the equations computed for the 1:4 mortars, the coefficient for the effect of fineness was negative whereas for the neat cements of normal consistency it was positive. Fineness of the cement was apparently of no significance in the two concrete series. With the $1: 2.75$ mortars the 
effect of the fineness of the cement was possibly included to some extent in the air-content values of the 1:4 mortars used as one of the independent variables for the computations of the $1: 2.75$ mortar relationships. The use of silica modulus (S/ $(\mathrm{A}+\mathrm{F}))$ in the calculations for the $1: 4$ and $1: 2.75$ mortars resulted in lower S.D. values while the use of the $\mathrm{Fe}_{2} \mathrm{O}_{3}$ content of the cements resulted in lower S.D. values for the concrete series.

Water requirements increased with insoluble residue for the constant slump concretes, but decreased with the same variable for the 1:2.75 mortars. The $\mathrm{MgO}$ content of the cement appeared significant in equations for both the $1: 2.75$ and the $1: 4$ mortars but not in the equations for the concretes. As previously mentioned, water used for normal consistency of the neat pastes increased with total alkali. With the $1: 2.75$ and $1: 4$ mortars water requirement increased with increasing $\mathrm{Na}_{2} \mathrm{O}$ content, and with the concretes it decreased with increasing $\mathrm{K}_{2} \mathrm{O}$ content.

As shown previously, the use of some of the commonly determined variables in the computations produced significant relationships. In each of the series of equations it was noted that the additional use of certain minor constituents or trace elements resulted in a slightly better fit or lower standard deviation values. Judging from the tables showing the calculated contributions of the various independent variables, the apparent effect on the water requirements of some of these trace elements or some variable associated with the trace elements can be appreciable. It is recognized that some of the minor constituents or trace elements which are closely related chemically may supplement each other and should be considered together in the same manner as $\mathrm{Na}_{2} \mathrm{O}$ and $\mathrm{K}_{2} \mathrm{O}$ in the total alkali. It is also possible that, as with $\mathrm{MgO}$, there is no appreciable effect until a certain minimum is present. However, until more precise values are obtained, it does not appear justified to employ the trace elements in other than linear relationships and until further information is attained relative to their nature and role in the chemistry of cement, they are being treated separately rather than in any arbirtary combination. There was some evidence that even closely related oxides as $\mathrm{Na}_{2} \mathrm{O}$ and $\mathrm{K}_{2} \mathrm{O}$ or $\mathrm{CaO}$ and SrO did not behave in the same manner in their effects on the water requirements of the cements.

The effect of the trace elements on water requirements was often different for the neat cement pastes than for the two mortars, and, in general, their effect on the concretes was not clearly demonstrated. The latter effect may possibly be accounted for by the fact that the cement constitutes such a small percentage of the total volume of the concrete, and effects of the small amounts of these elements present in the cement are so diluted in a concrete mix by all of the other ingredients and variables in the mix. The observation that effects differ between pastes and mortars is harder to explain. For example, in the equations for water requirement of neat pastes (table 2-3), water requirement consistently decreases with increasing $\mathrm{Cu}$ content and increases with increasing $\mathrm{Zr}$ content. With both mortars, however, water requirement increases with increasing $\mathrm{Cu}$ content, and with the 1:4 mortars it decreases with increasing $\mathrm{Zr}$ content as well. (Equations with $\mathrm{Zr}$ as a variable with the $1: 2.75$ mortars are not shown because they did not show a significant relationship for this element). This phenomenon may be related to air content of the mortars, or to some effect associated with the sand, but there appears to be nothing in these data on which a satisfactory explanation of this apparent contradiction can be based. Further studies of the role of trace elements in cement reactions is indicated as desirable.

The separation of the cements in to two approximately equal groups based on the air content obtained in the 1:4 mortar test enabled the computation of another series of equations to demonstrate the effect of air content on the water requirements of the mortars and concretes.

Comparisons of significant independent variables may be made between the pairs of eqs (1) and (2), (3) and (4), (5) and (6), or (7) and (8) in table $2-23$ or between these equations and those previously presented for $\mathrm{AE}+\mathrm{NAE}$ and for NAE cements in tables $2-8,2-10,2-15$, and $2-20$, respectively. The S.D. values for "low-air" cements were in every instance less than those obtained in corresponding equations for the NAE cements presented in the previous tables. The S.D. values for the "high-air" cements were lower in 3 out of 4 of these equations than those obtained for the $\mathrm{AE}+\mathrm{NAE}$ cements presented in the previous tables. It may also be noted that the s.d. values for the coefficients of the independent variables in the present table are larger than the s.d. values of the same variables in corresponding previous equations. This same effect was previously noted in comparing the s.d. values for coefficients in the computations of the "odds" and "evens" in an array of cements with the s.d. values obtained when all cements were used in an equation. The larger s.d. values obtained with the smaller number of cements in the equations of table 2-23 may have caused a coef./s.d. ratio of less than 1 for some of the variables of marginal significance which resulted in their elimination. It is also of interest to note that in eq (1) of table 2-23 the air content (as determined on the 1:4 mortars) was not a significant variable, whereas it was significant in the 1:4 mortar's and concretes.

Although the use of all possible combinations of independent variables in trial equations would have been impracticable, it is believed that with the use of the high-low comparison (see ref. [6]) with the deviations most of the more important variables on which tests were made have been included in the equations presented. 


\section{Summary and Conclusions}

(1) Tests were made on 199 portland cements of different types and from different mills in order to determine the interrelation of the cement and concrete properties and the independent variables associated with the various properties. This section deals with the water requirements of neat pastes, of $1: 4$ and $1: 2.75$ motars of standard consistency, and nominal $5 \frac{1}{2}$ bags $/ \mathrm{yd}^{3}$ concretes having a $5 \pm 1 \mathrm{in}$. slump, as well as with the slump values of the $5 \frac{1}{2}$ bags $/ \mathrm{yd}^{3}$ concretes using a water-cement ratio of 0.635 .

(2) The frequency distributions of the different dependent and independent variables conformed to the normal distribution, especially for non-air-entraining cements, and are believed to be fairly typical and to indicate the range of these variables which may be expected with portland cements.

(3) Comparisons of the estimated standard deviations computed from all of the determined values for the dependent variables with those of the respective computed multivariable equations indicated that in each instance certain commonly determined independent variables or cement characteristics were associated with the water requirements. The use in the equations of certain minor or trace elements not commonly determined resulted in equations with improved ability to predict the water requirements of the cements in many cases.

(4) Computations of multivariable equations by the least squares method with all the cements used in this investigation which included both the air-entraining and non-air-entraining cements or only the non-air-entraining cements indicated that a number of independent variables of these cements were associated either directly or indirectly with the amounts of water required for normal consistency of the neat cements, for standard consistency of the mortars, or for concretes of constant slump; or were associated with the slump values of concretes of constant watercement ratio. The following observations relate to the results obtained with the combination of both air-entraining and non-air-entraining portland cements and particularly to those equations in which the $\mathrm{Al}_{2} \mathrm{O}_{3}$ content of the cement was included as one of the independent variables:

(4.1) For neat portland cement pastes of normal consistency, water requirement increased with increasing air-permeability fineness, $\mathrm{Al}_{2} \mathrm{O}_{3}$, $\mathrm{CaO}, \mathrm{SO}_{3}$, or $\mathrm{Zr}$; and decreased with increasing $\mathrm{Cu}, \mathrm{P}$, or $\mathrm{SrO}$. Of these variables, difference in fineness appeared to have the greatest effect.

(4.2) For the 1:4 cement to 20-30 Ottawa sand mortars of standard consistency, water requirement increased with increasing $\mathrm{Al}_{2} \mathrm{O}_{3}$, silica modulus, $\mathrm{MgO}$, or $\mathrm{Na}_{2} \mathrm{O}$ of the commonly determined variables, and with increasing $\mathrm{Cu}$, Ti, $\mathrm{V}$, or $\mathrm{Rb}$; whereas it decreased with increasing air content, fineness, insoluble residue, and $\mathrm{Zr}$. Besides the air content, the $\mathrm{Al}_{2} \mathrm{O}_{3}$ and silica modulus values appeared to have the greatest effect on the amount of water required for standard consistency.

(4.3) For the 1:2.75 cement to graded Ottawa sand mortars of standard consistency, water requirement increased with increasing $\mathrm{Al}_{2} \mathrm{O}_{3}$, silica modulus, $\mathrm{Na}_{2} \mathrm{O}, \mathrm{MgO}$, and $\mathrm{SO}_{3}$ of the commonly determined variables, and with increasing $\mathrm{Cu}, \mathrm{Li}$, and $\mathrm{Pb}$; but decreased with increasing air content of the 1:4 mortars (values for air content of the 1:2.75 mortars not being available), insoluble residue, and $\mathrm{SrO}$. In addition to the air-entraining characteristics of the cements the $\mathrm{Al}_{2} \mathrm{O}_{3}$ and silica modulus values appeared to have the greatest effect on the water required for standard consistency.

(4.4) For the constant slump concretes, water requirement increased with increasing insoluble residue (one of the commonly determined variables of the cements), as well as with $\mathrm{Co}$ and $\mathrm{Pb}$; and decreased with increasing air content of the concrete and $\mathrm{Fe}_{2} \mathrm{O}_{3}, \mathrm{~K}_{2} \mathrm{O}$, and $\mathrm{Ba}$ in the cement. In addition to the entrained-air values the $\mathrm{Al}_{2} \mathrm{O}_{3}$ and $\mathrm{Fe}_{2} \mathrm{O}_{3}$ of the cement appeared to have the greatest effect on the water requirements of the constant slump concrete.

(4.5) For the constant-water-cement-ratio concretes, slump increased with increasing air content of the concrete, and with $\mathrm{Fe}_{2} \mathrm{O}_{3}$ and $\mathrm{K}_{2} \mathrm{O}$ of the commonly determined constituents of the cement, as well as with $\mathrm{Ba}$ and $\mathrm{Pb}$; and decreased with increasing $\mathrm{Al}_{2} \mathrm{O}_{3}, \mathrm{SO}_{3}$, and $\mathrm{Co}_{0}$ in the cement. In addition to the entrained-air values, the $\mathrm{Al}_{2} \mathrm{O}_{3}$ and $\mathrm{Fe}_{2} \mathrm{O}_{3}$ contents of the cements had the greatest effect on the slump of the concretes made with a constant water-cement ratio.

(5) 'The use of the $A / F$ ratio or the potential $\mathrm{C}_{3} \mathrm{~A}$ instead of the percentage of $\mathrm{Al}_{2} \mathrm{O}_{3}$ in the cements as one of the independent variables resulted in similar equations but with slight differences in the coefficients of the other independent variables.

(6) When equations were computed using only the non-air-entraining cements the same independent variables were generally significant but not to the same degree as when the air-entraining cements were included in the computations.

(7) Equations computed for the "odds" and "evens" in an array of cements were in general concordant and enhanced confidence in the coefficients of the different independent variables obtained from the complete set. The coefficients of the independent variables and the standard deviation of the equation computed from all the cements were bracketed by those computed from the "odds" and "evens" in the array. "The standard deviation attributed to each of the coefficients of the independent variables was almost always greater for the "odds" and "evens" when compared to the values for the entire lot. 
(8) The equations computed for the mortars and concretes using the cements having less than 7.0 percent air contents in the $1: 4$ mortar test and those having 7.0 percent or more air in this test demonstrated that the effect on water requirements and slump of many of the independent variables was different for the low-air and highair cements. However, with the smaller number of samples in each of the groups, the uncertainty with respect to the individual coefficients of the different independent variables was usually greater. With a few exceptions the variables indicated in the computations for the $\mathrm{AE}+\mathrm{NAE}$ or the NAE cements as being highly significant were also significant in computations for the the "low-air" and "high-air" groups of cements. The variables of marginal significance in equations for the $\mathrm{AE}+\mathrm{NAE}$ and $\mathrm{NAE}$ cements were often not significant when the computations were made for the "low-air" and "high-air" cements.

(9) In general, slump and water requirements of the concretes were significantly related to water requirements of the $1: 4$ and $1: 2.75$ mortars with the relationship being better with the $\mathrm{AE}+\mathrm{NAE}$ cements than with NAE cements alone.
(10) The lack of precision of the equations is attributed in part to various factors such as the leeway in water used for normal and standard consistency determinations, normal variability of test results, lack of adequate range of values for some of the independent properties known to be carefully controlled in manufacture, and lack of information of certain independent variables as well as the effect of interaction of so-called independent variables.

Acknowledgments are made to the heads of branch laboratories of the National Bureau of Standards at Allentown, Pa., Denver, Colo., San Francisco, Calif., and Seattle, Wash., G. Stiller, O. H. Cox, O. C. Marek, and Frank Winblade, respectively, as well as their associates and coworkers, and to M. R. DeFore and Leonard Bean and associates in the Washington laboratory for making the many tests involved. Acknowledgments are also made to D. N. Evans for collecting, checking, and compiling the data.

\section{References}

[1] Federal Test Method Standard: Cements, Hydraulic, Sampling, Inspection, and Testing, SS-C-158.

[2] Standard Method of Test for Normal Consistency of Hydraulic Cement, ASTM Designation C 187-58.

[3] Standard Method of Test for Compressive Strength of Hydraulic Cement Mortars (using 2-in. cube specimens), ASTM Designation C 109-58.

[4] Standard Method of Test for Air Content of Hydraulic Cement Mortar, ASTM Designation C 185-59.

[5] R. L. Blaine, J. C. Yates, and J. R. Dwyer, The testing of portland cement containing interground vinsol resin, Proc. ASTM 45, 732 (1945).
[6] Interrelation between cement and concrete properties: materials and techniques, of this paper Section 1.

[7] D. A. Abrams, Discussion on portland cement containing vinsol resin, Proc. ASTM 45, 755 (1945).

[8] R. F. Blanks and H. L. Kennedy, The Technology of Cement and Concrete, Vol. 1, Concrete Materials, pp. 247-250, (John Wiley \& Sons, Inc., New York, N.Y.). 


\title{
Section 3. Occurrence of Minor and Trace Elements in Portland Cement
}

\author{
R. L. Blaine, Leonard Bean, and Elizabeth K. Hubbard
}

\begin{abstract}
Minor and traee elements in 186 portland eements were determined by spectrographie analyses. The semiquantitative values obtained ranged up to 1 pereent for $\mathrm{Ti}$ and $\mathrm{Mn}$, to 0.5 pereent for $\mathrm{P}$, and $\mathrm{Zr}$, to 0.2 pereent for $\mathrm{Ba}$ and $\mathrm{Zn}$, to 0.1 pereent for $\mathrm{V}$, to 0.05 pereent for $\mathrm{Cu}, \mathrm{Mo}$, and $\mathrm{Pb}$. Other elements sueh as $\mathrm{Cr}, \mathrm{Li}, \mathrm{Ni}, \mathrm{Co}, \mathrm{Rb}, \mathrm{Ag}, \mathrm{B}$, and Sn were found in lesser amounts in some of the eements. The quantities of $\mathrm{Na}_{2} \mathrm{O}, \mathrm{K}_{2} \mathrm{O}$, and $\mathrm{SrO}$ as determined by flame photometrie methods were determined in 199 portland eements. The frequeney distributions are presented and the effeet of these minor and traee elements on the oxide values and the caleulated eompound eomposition values are diseussed.
\end{abstract}

Contents

$\begin{array}{ll}\text { 1. Introduction } & \text { Page } \\ \text { 2. Materials } & 33 \\ \text { 3. Testing proeedures } & \\ \text { 4. Results of tests } & \\ \text { 5. Diseussion } & \\ \text { 6. Summary } & \text { Referenees }\end{array}$

\section{Introduction}

It has long been recognized that portland cements contain small quantities of elements other than those present in the larger quantities to which hydraulic and other properties are generally attributed. These trace elements have been referred to as minor elements, minor constituents and even as impurities. The presence of these elements in portland cement may result from their existence in the raw materials from which the cement is made, from the ash in the coal used in the burning of the clinker, from the lining of the cement kiln, from the attrition of grinding media and lining of the grinding mill, or may in some instances be added to enhance the clinkering characteristics or the properties of the cement or even to procure a desirable by-product.

The importance of the minor and trace elements in stabilizing the silicate compounds such as are formed in the manufacture of cement was shown by Bates and Klein in 1917 [1]. ${ }^{1}$ In papers presented at the 1952 Third International Symposium on the Chemistry of Cement, Jeffery [2] and Nurse [3] summarized and discussed work in this field. Further summaries of the effects of minor and trace elements were made in the 1960 Fourth
International Symposium on the Chemistry of Cement by Nurse [4], Welch and Gutt [5], Heilmann [6], Locher [7], Woermann [8], Toropov [9], and others. It was concluded by a number of these authors that the presence of minor components can greatly influence the properties of the major compounds and therefore also the properties of the portland cements, and that further information relative to the minor and trace elements was needed.

There have been numerous reports of the presence and effect of some of the minor and trace elements such as $\mathrm{Na}, \mathrm{K}, \mathrm{Sr}, \mathrm{Ti}, \mathrm{P}$, and $\mathrm{Mn}$, but very little information is available relative to other elements. It appeared desirable, therefore, in the Study of the Interrelations Between Cement and Concrete Properties to obtain further information on the occurrence of all minor and trace elements in portland cement and to determine, at least in a semiquantitative manner, the amounts of these elements which may be present.

The effects, if any, of these minor and trace elements on the physical properties of the cements will be discussed in other sections in this series dealing with specific properties of the cements and concretes.

\section{Materials}

The 186 portland cements analyzed in this investigation have been described in a previous section [10]. The samples are believed to be

\footnotetext{
1 Figures in brackets indicate the literature references at the end of this
} section. fairly representative of different types of portland cement produced in different areas of the United States. Only a few of the cements were procured from overseas. 


\section{Testing Procedures}

The procedures and apparatus used for the semiquantitative spectrographic analyses were as follows: A $5 \mathrm{mg}$ portion of the portland cement sample was mixed with $2 \mathrm{mg}$ of high-purity graphite powder which acted as a buffer to assist in volatilizing the sample. This charge was placed in a graphite electrode having a shallow cup, and was vaporized and excited in a $d-c$ are with a current of $15 \mathrm{~A}$. The light from the arc, passing through a slit of the spectrograph was dispersed into a spectrum and this was photographed in the spectral range 2200-4800 $\AA$ on Eastman 33 plates, $4600-6000 \AA$ on Eastman II-F plates and 66008000 A on Eastman I-N plates. The spectrograph used for this work had a Wadsworth mounting of a concave grating, the grating having 15,000 lines per inch and a radius of curvature of $21 \mathrm{ft}$. The spectrograph produced a spectrum with linear dispersion of $5 \AA$ per $\mathrm{mm}$ in the first order.

The spectrograms of the cement samples were compared with those of synthetic standards of $3 \mathrm{CaO} \cdot \mathrm{SiO}_{2}$ containing known amounts of the trace elements commonly found in portland cements, and semiquantitative values were assigned each element present based on a combination of visual estimations and photometric measurements. Duplicate determinations were made on all samples.

The determinations of $\mathrm{Na}_{2} \mathrm{O}$ and $\mathrm{K}_{2} \mathrm{O}$ were made by Federal Specification methods [11] and $\mathrm{SrO}$ by a flame photometric procedure which has previously been described [12].

\section{Results of Tests}

The frequency distribution of the minor and trace elements as determined by the spectrographic analyses is presented in table 3-1, and the frequency distribution of the minor and trace elements as determined by flame photometric techniques is presented in table $3-2$. Elements other than those indicated in the tables were not detected or were present in quantities less than 0.001 percent. The semiquantitative values reported in table $3-1$ are for the elements. If they had been reported as oxides, as is customary in cement analyses, the values would be correspondingly higher.

A comparison of values for Mn obtained by the spectrographic analyses with those obtained by regular chemical analyses on a number of cements indicated close agreement between the results obtained by the two methods.
The frequency distribution of the cements with the greatest quantities of the minor and trace elements as found in different areas of the United States is presented in table $3-3$. It may be noted that a number of cements obtained from east of the Mississippi River, areas 1 through 5, had high values for $\mathrm{Mn}, \mathrm{P}$, and $\mathrm{Zn}$. Although not indicated in table $3-3$ the highest values for $\mathrm{Zr}$, 0.5 percent, was from area 5 . A number of the cements obtained from areas 6 and 7 , between the Mississippi River and the West Coast area, had high values for $\mathrm{Co}, \mathrm{Cr}, \mathrm{Mn}, \mathrm{Ni}, \mathrm{Pb}$, Ti, and $\mathrm{Zr}$, whereas a number of cements obtained from the West Coast areas had high values for $\mathrm{Co}, \mathrm{Cu}$, $\mathrm{Li}, \mathrm{Mo}, \mathrm{V}$, and $\mathrm{Zn}$. The prevalence as well as variety of the larger quantities of most of the minor and trace elements was greater west of the Mississippi than in the eastern part of the country.

\section{Discussion}

In many instances a number of different types of cements were obtained from a single manufacturing plant. The distribution of values presented may therefore not truly represent that distribution of values which would have been obtained if an equal number of cements had been obtained from each of the mills.

The reported oxides and calculated compound composition values resulting from the regular chemical analyses of portland cement may be in error as a result of the presence of the minor and trace elements. The effect of the presence of these elements on an ordinary analysis, if not removed or determined, is described in a number of standard texts [13]. For example, Ba would normally be expected to be included with the $\mathrm{Al}_{2} \mathrm{O}_{3}$ value. Some of the $\mathrm{Co}_{0}$ would also be included with the $\mathrm{Al}_{2} \mathrm{O}_{3}$ but most of the $\mathrm{Co}$ would be in the Ca value. The $\mathrm{Cr}$ would also be included with the $\mathrm{Al}_{2} \mathrm{O}_{3}$ as would a portion of the $\mathrm{Cu}$; the remainder of the $\mathrm{Cu}$ would probably be lost. L is generally lost in the course of an ordinary analysis together with the other alkalies when not determined. Some of the Mn may be included with the $\mathrm{Al}_{2} \mathrm{O}_{3}$, some with the $\mathrm{CaO}$, precipitated as calcium manganite or manganese oxalate, and some will be included with the $\mathrm{MgO}$. When referee methods are used, the $\mathrm{Mn}$ is removed. Mo, if present, would probably be included with the $\mathrm{Al}_{2} \mathrm{O}_{3}$, whereas some of the $\mathrm{Ni}$ would be included with the $\mathrm{CaO}$ and some would be lost. The $\mathrm{P}$ would be included with the $\mathrm{Al}_{2} \mathrm{O}_{3}$. $\mathrm{Pb}$ may also be distributed between the $\mathrm{Al}_{2} \mathrm{O}_{3}$, the $\mathrm{CaO}$, and the $\mathrm{MgO}$. The $\mathrm{Rb}$ is probably lost by our present methods but may possibly affect the $\mathrm{K}_{2} \mathrm{O}$ values. In the regular and referee chemical methods the $\mathrm{SrO}$ is included with the $\mathrm{CaO}$. The Ti, unless determined, is included with the $\mathrm{Al}_{2} \mathrm{O}_{3}$ as is part of the $\mathrm{V}$, the remainder being reported with the $\mathrm{CaO}$. Some of the $\mathrm{Zn}$ 
TABLE 3-1. Frequency of occurrence of different percentages of minor and trace elements in portland cements as delermined by spectrographic analysis

\begin{tabular}{|c|c|c|c|c|c|c|c|c|c|c|c|c|}
\hline \multirow{2}{*}{ Element } & \multirow{2}{*}{$\begin{array}{l}\text { Lower limit of } \\
\text { reporting }\end{array}$} & \multirow{2}{*}{$\begin{array}{l}\text { Cements below } \\
\text { lower limit of } \\
\text { reporting }\end{array}$} & \multicolumn{10}{|c|}{ Approximate pereentage present as clements } \\
\hline & & & 0.001 & 0.002 & 0.005 & 0.01 & 0.02 & 0.05 & 0.1 & 0.2 & 0.5 & 1.0 \\
\hline $\mathrm{Ba}_{2-}$ & $\begin{array}{l}\text { Percent } \\
0.01\end{array}$ & 13 & & & & 79 & 58 & 26 & 6 & 4 & & \\
\hline Co.- & .001 & 139 & 26 & 10 & 10 & 1 & & & & & & - \\
\hline $\mathrm{Cr}$ & .001 & 1 & 6 & 27 & 86 & 55 & 11 & -- & $-\ldots \ldots \ldots$ & $\ldots$ & $-\ldots$ & $\cdots$ \\
\hline $\mathrm{Cu}$ & $\begin{array}{r}.001 \\
.005\end{array}$ & $\begin{array}{r}5 \\
168\end{array}$ & 18 & 52 & $\begin{array}{r}55 \\
1\end{array}$ & $\begin{array}{l}39 \\
15\end{array}$ & $\begin{array}{r}12 \\
2\end{array}$ & 5 & $-1-2-1$ & $-\cdots$ & -- & $-1-2-1$ \\
\hline $\begin{array}{l}\mathrm{Li} \\
\mathrm{Mn}\end{array}$ & .01 & 1 & & & & 4 & 26 & 78 & 56 & 11 & 8 & - \\
\hline $\mathrm{Mo}$ & .001 & 170 & 6 & 1 & 5 & & & 4 & & & & $\ldots$ \\
\hline Ni.......... & .001 & 16 & 58 & 43 & 46 & 22 & 1 & $\ldots$ & $\ldots$. & $-\ldots$ & $\ldots$ & hand \\
\hline $\mathrm{P}-\ldots \ldots \ldots$ & .1 & $\begin{array}{l}172 \\
155\end{array}$ & 11 & 5 & --- & $-\overline{5}$ & $-\overline{3}$ & -1 & 4 & 1 & 9 & - \\
\hline Rb. & .001 & 145 & 6 & 1 & 33 & 1 & & & & & -- & - not \\
\hline Ti_........- & .05 & 0 & & & & & $-=$ & 7 & 49 & 115 & 14 & \\
\hline$V_{0}-n_{0}$ & .01 & $\begin{array}{r}83 \\
169\end{array}$ & n-n...... & -....... & & 62 & 25 & 12 & 4 & $\cdots$ & 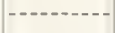 & $-\cdots$ \\
\hline 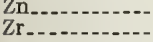 & .01 & $\begin{array}{r}162 \\
1\end{array}$ & - & 1 & 83 & $\begin{array}{r}1 \\
83\end{array}$ & $\begin{array}{l}2 \\
9\end{array}$ & $\begin{array}{l}8 \\
6\end{array}$ & $\begin{array}{r}11 \\
1\end{array}$ & $\begin{array}{l}2 \\
1\end{array}$ & 1 & (-n) \\
\hline
\end{tabular}

$\mathrm{Ag}, \mathrm{B}$, and Sn were also present in some cements in quantities less than 0.001 percent.

TABLE 3-2. Frequency distribution of oxides of minor and trace elements in portland cements as determined by flame photometer method

\begin{tabular}{|c|c|c|c|c|c|c|c|c|c|c|c|c|c|c|c|}
\hline \multicolumn{16}{|c|}{ Percentage present } \\
\hline Oxide & $\begin{array}{l}0.00 \\
\text { to } \\
.05\end{array}$ & $\begin{array}{l}0.05 \\
\text { to } \\
.10\end{array}$ & $\begin{array}{l}0.10 \\
\text { to } \\
.15\end{array}$ & $\begin{array}{l}0.15 \\
\text { to } \\
.20\end{array}$ & $\begin{array}{l}0.20 \\
\text { to } \\
.25\end{array}$ & $\begin{array}{l}0.25 \\
\text { to } \\
.30\end{array}$ & $\begin{array}{l}0.30 \\
\text { to } \\
.35\end{array}$ & $\begin{array}{l}0.35 \\
\text { to } \\
.40\end{array}$ & $\begin{array}{l}0.40 \\
\text { to } \\
.45\end{array}$ & $\begin{array}{l}0.45 \\
\text { to } \\
.50\end{array}$ & $\begin{array}{l}0.50 \\
\text { to } \\
.55\end{array}$ & $\begin{array}{l}0.55 \\
\text { to } \\
.60\end{array}$ & $\begin{array}{l}0.60 \\
\text { to } \\
.65\end{array}$ & $\begin{array}{l}0.65 \\
\text { to } \\
.70\end{array}$ & $\begin{array}{l}0.70 \\
\text { to } \\
.75\end{array}$ \\
\hline $\begin{array}{l}\mathrm{Na}_{2} \mathrm{O} \\
\mathrm{SrO}\end{array}$ & $\begin{array}{l}16 \\
22\end{array}$ & $\begin{array}{l}34 \\
70\end{array}$ & $\begin{array}{l}48 \\
41\end{array}$ & $\begin{array}{l}22 \\
24\end{array}$ & $\begin{array}{l}27 \\
11\end{array}$ & $\begin{array}{l}10 \\
12\end{array}$ & $\begin{array}{r}12 \\
8\end{array}$ & $\begin{array}{r}12 \\
9\end{array}$ & 4 & 3 & 6 & 2 & 1 & 0 & 1 \\
\hline Oxide--. & $\begin{array}{c}0 \\
\text { to } \\
0.1\end{array}$ & $\begin{array}{l}0.10 \\
\text { to } \\
.20\end{array}$ & $\begin{array}{l}0.20 \\
\text { to } \\
.30\end{array}$ & $\begin{array}{l}0.30 \\
\text { to } \\
.40\end{array}$ & $\begin{array}{l}0.40 \\
\text { to } \\
.50\end{array}$ & $\begin{array}{l}0.50 \\
\text { to } \\
.60\end{array}$ & $\begin{array}{l}0.60 \\
\text { to } \\
.70\end{array}$ & $\begin{array}{l}0.70 \\
\text { to } \\
.80\end{array}$ & $\begin{array}{c}0.80 \\
\text { to } \\
.90\end{array}$ & $\begin{array}{c}0.90 \\
\text { to } \\
1.00\end{array}$ & $\begin{array}{c}1.00 \\
\text { to } \\
1.10\end{array}$ & $\begin{array}{l}1.1 \\
\text { to } \\
1.2\end{array}$ & $\begin{array}{l}1.2 \\
\text { to } \\
1.3\end{array}$ & $\begin{array}{l}1.3 \\
\text { to } \\
1.4\end{array}$ & \\
\hline $\begin{array}{l}\mathrm{K}_{2} \mathrm{O} \\
\quad \mathrm{Total} \mathrm{Alk} \text { as } \mathrm{Na}_{2} \mathrm{O}\left(\mathrm{Na}_{2} \mathrm{O}\right.\end{array}$ & $\begin{array}{l}8 \\
2\end{array}$ & $\begin{array}{l}21 \\
12\end{array}$ & $\begin{array}{l}24 \\
25\end{array}$ & $\begin{array}{l}23 \\
25\end{array}$ & $\begin{array}{l}38 \\
39\end{array}$ & $\begin{array}{l}27 \\
36\end{array}$ & $\begin{array}{l}22 \\
24\end{array}$ & $\begin{array}{l}15 \\
19\end{array}$ & $\begin{array}{l}15 \\
12\end{array}$ & $\begin{array}{l}4 \\
4\end{array}$ & $\begin{array}{l}2 \\
1\end{array}$ & & 2 & & \\
\hline
\end{tabular}

TABLE 3-3. Frequency distribution of cements with the larger quantities of minor and trace elements in different areas of the United States

\begin{tabular}{|c|c|c|c|c|c|c|c|c|c|c|c|c|}
\hline \multirow{2}{*}{$\begin{array}{l}\text { Minor or trace } \\
\text { element }\end{array}$} & \multirow{2}{*}{$\begin{array}{l}\text { Quantity present } \\
\text { percentage }\end{array}$} & \multicolumn{11}{|c|}{ Area in $\mathrm{USA}^{*}$} \\
\hline & & 1 & 2 & 3 & 4 & 5 & 6 & 7 & 8 & 9 & 10 & 11 \\
\hline $\begin{array}{l}\mathrm{Ba} \\
\mathrm{Co}\end{array}$ & $\begin{array}{c}0.1-0.2 \\
0.005-0.01\end{array}$ & 1 & $\begin{array}{l}2 \\
1\end{array}$ & 1 & 1 & & & & 1 & 4 & 2 & \\
\hline $\mathrm{Cr}$ & 0.02 & & 1 & & & 1 & $\begin{array}{l}1 \\
2\end{array}$ & $\begin{array}{l}3 \\
3\end{array}$ & $\overline{1}$ & 2 & 1 & \\
\hline $\mathrm{Cu}$ & $0.02-0.05$ & 1 & & 2 & 1 & 1 & & & 1 & 3 & 3 & 7 \\
\hline $\mathrm{Mn}$ & $\begin{array}{l}0.01-0.02 \\
0.2-0.5\end{array}$ & $-\infty$ & $-1-1-1$ & 6 & 1 & $-1-2-1$ & 4 & 3 & $\begin{array}{l}1 \\
2\end{array}$ & 5 & $\begin{array}{r}11 \\
2\end{array}$ & -1 \\
\hline Mo-. & $0.005-0.05$ & 等 & 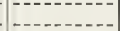 & & & - & & & 1 & 2 & 5 & 1 \\
\hline $\mathrm{Ni}$ & $\begin{array}{c}0.01-0.02 \\
0.1-0.5\end{array}$ & - non & 2 & I & 1 & 1 & 4 & 9 & 3 & 3 & 3 & . \\
\hline${ }_{\mathrm{P}}^{\mathrm{P}}$ & $\begin{array}{c}0.1-0.5 \\
0.01-0.05\end{array}$ & & 2 & & & 3 & 5 & $\begin{array}{l}2 \\
1\end{array}$ & & & $\frac{1}{2}$ & \\
\hline $\mathrm{Ti}^{* * *}$ & $0.5-1.0$ & - & 1 & 1 & & . & 4 & 3 & 2 & I & & \\
\hline 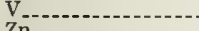 & $0.05-0.10$ & & & & 2 & & & 2 & 3 & 3 & 5 & \\
\hline $\begin{array}{l}\mathrm{Zn} \\
\mathrm{Zn}\end{array}$ & $\begin{array}{c}0.1-0.2 \\
0.02-0.50\end{array}$ & 1 & (n) & $\begin{array}{l}1 \\
1\end{array}$ & $\begin{array}{c}2 \\
--\end{array}$ & $\begin{array}{l}5 \\
3\end{array}$ & $-\overline{4}$ & 5 & 3 & -.. & & 1 \\
\hline
\end{tabular}

* Area No. States included-

1...- Eastern Pennsylvania, Maryland.

. New York, Maine.

3...- Ohio, Western Pennsylvania, West Virginia, Michigan.

4.... Illinois, Indiana, Kentucky, Wisconsin, Alabama, Tennessce

5....- Virginia, Georgia, Florida, Louisiana, South Carolina, Mis-

6...... Iowa, Eastern Missouri, Minnesota, South Dakota, Kansas.

**one from country other than U.S.A.
Area No. States included-

7. .... Western Missouri, Nebraska, Oklahoma, Arkansas, Texas.

8... Colorado, Arizona, Montana, Utah, Idaho.

9 ...... Northern California.

10...... Southern California.

$11 . . . .$. Washington, Oregon. 
would be included with the $\mathrm{Al}_{2} \mathrm{O}_{3}$ and the remainder precipitated as the oxyquinolate causing an error in the $\mathrm{MgO}$ value. The $\mathrm{Zr}$ would also be included with the $\mathrm{Al}_{2} \mathrm{O}_{3}$. Although the quantities of the minor and trace elements are small it may be noted from the above discussion that $\mathrm{Ba}, \mathrm{Cr}, \mathrm{Mo}, \mathrm{P}$, 'Ti, Zr, as well as portions of the $\mathrm{Co}, \mathrm{Cu}, \mathrm{Mn}, \mathrm{Pb}, \mathrm{V}$, and $\mathrm{Zn}$ are included with the $\mathrm{Al}_{2} \mathrm{O}_{3}$. The computed tricalcium aluminate value would then be larger than actual whereas the tricalcium silicate value would be smaller than actual. This is in agreement with the report by
Insley and coworkers [14] and the summary presented by Lea and Desch [15], p 143.

A more serious effect of the minor and trace elements has also been discussed by Lea and Desch (15), p. 139, where it was shown that minor components can cause displacements of the clinker equilibrium fields.

As mentioned in the introduction, the effect, if any, of these minor and trace elements on the properties of cement will be treated in other sections on the properties of the cements in this investigation.

\section{Summary}

Minor and trace elements in 186 portland cements were determined by spectrographic analyses. The semiquantitative values obtained ranged up to 1.0 percent for $\mathrm{Ti}$ and $\mathrm{Mn}$, to 0.5 percent for $\mathrm{P}$ and $\mathrm{Zr}$, to 0.2 percent for $\mathrm{Ba}$ and $\mathrm{Zn}$, to 0.1 percent for $\mathrm{V}$, to 0.05 percent for $\mathrm{Cu}, \mathrm{Mo}$, and $\mathrm{Pb}$, to 0.02 percent for $\mathrm{Cr}, \mathrm{Li}$, and $\mathrm{Ni}$, and to 0.01 percent for $\mathrm{Co}$ and $\mathrm{Rb}$. Ag, B, and Sn were present in some portland cements in quantities less than 0.001 percent. The quantities of $\mathrm{Na}_{2} \mathrm{O}$, $\mathrm{K}_{2} \mathrm{O}$, and $\mathrm{SrO}$ as determined by flame photometric methods in 199 portland cements were also determined.

The frequency distribution of the minor and trace elements in portland cements are presented as are the frequency of occurrence of high values in different areas of the United States.

The effect of these minor and trace elements on the oxide values obtained by routine analyses and the calculated compound composition values are discussed. In view of the fact that many of the trace elements would be included with the alumina, the calculated tricalcium aluminate value is probably high and the tricalcium silicate value is correspondingly low. Attention is also called to the effect of minor elements on the equilibrium values of the major components.

The effect, if any, of the minor and trace elements on the physical properties of the cements will be presented in future sections dealing with properties of these cements.

\section{References}

[1] P. H. Bates and A. A. Klein, Bureau of Standards Tech. Paper 78 (1921).

[2] J. W. Jeffery, The Tricalcium Silicate Phase, Proc. Third International Symposium on the Chemistry of Cement, London (1952), p. 30.

[3] R. W. Nurse, The Dicalcium Silicate Phase, Proc. Third International Symposium on the Chemistry of Cement, London (1952), p. 56.

[4] R. W. Nurse, Phase Equilibria and Constitution of Portland Cement Clinker, Proc. Fourth International Symposium on the Chemistry of Cement, Washington (1960), p. 9.

[5] J. H. Welch and W. Gutt, The Effect of Minor Components on the Hydraulicity of the Calcium Silicates, Proc. Fourth International Symposium on the Chemistry of Cement, Washington (1960), p. 59 .

[6] T. Heilmann, Reactions of Coal Ash with Portland Cement Clinker During the Burning Process, Proc. Fourth International Symposium on the Chemistry of Cement, Washington (1960), p. 87.

[7] F. W. Locher, Solid Solution of Alumina and Magnesia in Tricalcium Silicate, Proc. Fourth International Symposium on the Chemistry of Cement, Washington $(1960)$, p. 99 .
[8] E. Woermann, Decomposition of Alite in Technical Portland Cement Clinker, Proc. Fourth International Symposium on the Chemistry of Cement, Washington (1960), p. 119.

[9] N. A. Toropov, Solid Solutions of the Minerals of Portland Cement Clinkers, Proc. Fourth International Symposium on the Chemistry of Cement, Washington (1960), p. 113.

[10] Interrelations between cement and concrete properties; materials and techniques, of this publication.

[11] Federal Specifications SS-C-158c Amendment 1; Cements, Hydraulic, Methods for Sampling, Inspection and Testing, May 25, 1954.

[12] J. J. Diamond, Photometric determination of strontium in portland cement, Anal. Chem. 27, 913, June 1955.

[13] W. F. Hillebrand, G. E. F. Lundell, H. A. Bright, and J. J. Hoffman, Applied Inorganic Analysis, 2d Edition (John Wiley \& Sons, Inc., New York, N.Y.).

[14] H. Insley, E. P. Flint, E. S. Newman, and J. A. Swenson, J. Res. NBS, 21, 355 (1938) RP1135.

[15] F. M. Lea and C.'H. Desch, The Chemistry of Cement and Concrete (revised edition) (1956), Edward Arnold (Publishers) Ltd. 


\section{Announcement of New Publications in Building Science Series}

Superintendent of Documents, Government Printing Office, Washington, D.C., 20402

Dear Sir:

Please add my name to the announcement list of new publications to be issued in the series: National Bureau of Standards Building Science Series.

Name

Company

Address

City State Zip Code

(Notification key $\mathrm{N}-339$ ) 





\section{THE NATIONAL BUREAU OF STANDARDS}

The National Bureau of Standards is a principal focal point in the Federal Government for assuring maximum application of the physical and engineering sciences to the advancement of technology in industry and commerce. Its responsibilities include development and maintenance of the national standards of measurement, and the provisions of means for making measurements consistent with those standards; determination of physical constants and properties of materials; development of methods for testing materials, mechanisms, and structures, and making such tests as may be necessary, particularly for government agencies; cooperation in the establishment of standard practices for incorporation in codes and specifications; advisory service to government agencies on scientific and technical problems; invention and development of devices to serve special needs of the Government; assistance to industry, business, and consumers in the development and acceptance of commercial standards and simplified trade practice recommendations; administration of programs in cooperation with United States business groups and standards organizations for the development of international standards of practice; and maintenance of a clearinghouse for the collection and dissemination of scientific, technical, and engineering information. The scope of the $\mathrm{Bu}$ reau's activities is suggested in the following listing of its four Institutes and their organizational units.

Institute for Basic Standards. Applied Mathematics. Electricity. Metrology. Mechanics. Heat. Atomic Physics. Physical Chemistry: Laboratory Astrophysics.* Radiation Physics. Radio Standards Laboratory:* Radio Standards Physics; Radio Standards Engineering. Office of Standard Reference Data.

Institute for Materials Research. Analytical Chemistry. Polymers. Metallurgy. Inorganic Materials. Reactor Radiations. Cryogenics.* Materials Evaluation Laboratory. Office of Standard Reference Materials.

Institute for Applied Technology. Building Research. Information Technology. Performance Test Development. Electronic Instrumentation. Textile and Apparel Technology Center. Technical Analysis. Office of Weights and Measures. Office of Engineering Standards. Office of Invention and Innovation. Office of Technical Resources. Clearinghouse for Federal Scientific and Technical Information.**

Central Radio Propagation Laboratory.* Ionospheric Telecommunications. Tropospheric Telecommunications. Space Environment Foręcasting. Aeronomy.

* Located at Boulder, Colo., 80301.

** Located at 5285 Port Royal Road, Springfield, Va., 22171. 
U.S. DEPARTMENT OF COMMERCE

WASHINGTON, D.C. 20230

OFFICIAL BUSINESS
POSTAGE AND FEES PAID

U.S. DEPARTMENT OF COMMERCE 